\title{
Kinematics of the South Atlantic rift
}

\author{
C. Heine ${ }^{1, *}$, J. Zoethout ${ }^{2}$, and R. D. Müller ${ }^{1}$ \\ ${ }^{1}$ EarthByte Group, School of Geosciences, Madsen Buildg. F09, The University of Sydney, NSW 2006, Australia \\ ${ }^{2}$ Global New Ventures, Statoil ASA, Forus, Stavanger, Norway \\ *formerly at: GET GME TSG, Statoil ASA, Oslo, Norway \\ Correspondence to: C. Heine (christian.heine@sydney.edu.au)
}

Received: 5 January 2013 - Published in Solid Earth Discuss.: 16 January 2013

Revised: 16 June 2013 - Accepted: 18 June 2013 - Published: 1 August 2013

\begin{abstract}
The South Atlantic rift basin evolved as a branch of a large Jurassic-Cretaceous intraplate rift zone between the African and South American plates during the final break-up of western Gondwana. While the relative motions between South America and Africa for post-break-up times are well resolved, many issues pertaining to the fit reconstruction and particularly the relation between kinematics and lithosphere dynamics during pre-break-up remain unclear in currently published plate models. We have compiled and assimilated data from these intraplated rifts and constructed a revised plate kinematic model for the pre-break-up evolution of the South Atlantic. Based on structural restoration of the conjugate South Atlantic margins and intracontinental rift basins in Africa and South America, we achieve a tight-fit reconstruction which eliminates the need for previously inferred large intracontinental shear zones, in particular in Patagonian South America. By quantitatively accounting for crustal deformation in the Central and West African Rift Zones, we have been able to indirectly construct the kinematic history of the pre-break-up evolution of the conjugate west African-Brazilian margins. Our model suggests a causal link between changes in extension direction and velocity during continental extension and the generation of marginal structures such as the enigmatic presalt sag basin and the São Paulo High. We model an initial E-W-directed extension between South America and Africa (fixed in present-day position) at very low extensional velocities from $140 \mathrm{Ma}$ until late Hauterivian times $(\approx 126 \mathrm{Ma})$ when rift activity along in the equatorial Atlantic domain started to increase significantly. During this initial $\approx 14 \mathrm{Myr}-$ long stretching episode the pre-salt basin width on the conjugate Brazilian and west African margins is generated. An intermediate stage between $\approx 126 \mathrm{Ma}$ and base Aptian is
\end{abstract}

characterised by strain localisation, rapid lithospheric weakening in the equatorial Atlantic domain, resulting in both progressively increasing extensional velocities as well as a significant rotation of the extension direction to NE-SW. From base Aptian onwards diachronous lithospheric breakup occurred along the central South Atlantic rift, first in the Sergipe-Alagoas/Rio Muni margin segment in the northernmost South Atlantic. Final break-up between South America and Africa occurred in the conjugate Santos-Benguela margin segment at around $113 \mathrm{Ma}$ and in the equatorial Atlantic domain between the Ghanaian Ridge and the Piauí-Ceará margin at $103 \mathrm{Ma}$. We conclude that such a multi-velocity, multi-directional rift history exerts primary control on the evolution of these conjugate passive-margin systems and can explain the first-order tectonic structures along the South Atlantic and possibly other passive margins.

\section{Introduction}

The formation and evolution of rift basins and continental passive margins is strongly dependend on lithosphere rheology and strain rates (e.g. Buck et al., 1999; Bassi, 1995). Strain rates are directly related to the relative motions between larger, rigid lithospheric plates and thus the rules of plate tectonics. A consistent, independent kinematic framework for the pre-break-up deformation history of the South Atlantic rift allows linking changes in relative plate velocities and direction between the main lithospheric plates to events recorded at basin scale and might help to shed light on some of the enigmatic aspects of the conjugate margin formation in the South Atlantic, such as the pre-salt sag basins along the west African margin (e.g. Huismans and Beaumont, 2011; 
Reston, 2010), the extinct Abimael Ridge in the southern Santos Basin, and the formation of the São Paulo High. Over the past decades, our knowledge of passive-margin evolution and the sophistication of lithospheric deformation modelling codes has substantially increased (e.g. Huismans and Beaumont, 2011; Péron-Pinvidic and Manatschal, 2009; Rüpke et al., 2008; Crosby et al., 2008; Lavier and Manatschal, 2006), as have the accuracy and understanding of global and regional relative plate motion models (e.g. Seton et al., 2012; Müller et al., 2008) for oceanic areas. However, the connections between these two scales and the construction of quantified plate kinematic frameworks for pre-break-up lithospheric extension remains limited due to the fact that no equivalent of oceanic isochrons and fracture zones are generated during continental lithospheric extension to provide spatio-temporal constraints on the progression of extension. Provision of such kinematic frameworks would vastly help to improve our understanding of the spatio-temporal dynamics of continental margin formation. The South Atlantic basin with its conjugate South American and west African margins and associated Late Jurassic/Early Cretaceous rift structures (Fig. 1) offers an ideal testing ground to attempt to construct such a framework and link a kinematic model to observations from marginal and failed rift basins. There are relatively few major lithospheric plates involved, the motions between these plates during the early extension phase can be modelled using well-documented intraplate rifts and the conjugate passive margins still exist in situ. In addition, an extensive body of published literature exists which documents detailed aspects of the conjugate passive-margin architecture.

\subsection{Aims and rationale}

Following Reston (2010), previously published plate kinematic reconstructions of the South Atlantic rift have only been able to address basic questions related to the formation of the conjugate South Atlantic margins in pre-seafloorspreading times and fall short of explaining the impact of plate kinematic effects on rift margin evolution. In this paper, we present a completely revised plate kinematic model for the pre-break-up and early seafloor-spreading history of the South Atlantic rift that integrates observations from all major South American and African rifts. We alleviate unnecessary complexity from existing plate tectonic models for the region - such as a number of large, inferred intracontinental shear zones, for which observational evidence is lacking - while providing a kinematic framework which can consistently explain relative plate motions between the larger lithospheric plates and smaller tectonic blocks. The model improves the full-fit reconstruction between South American plates and Africa, especially in the southernmost South Atlantic, and is able to explain the formation of the Salado and Colorado basins in Argentina, two Early Cretaceous-aged basins which strike nearly orthogonal to the main South Atlantic rift, in the context of larger-scale plate motions. This allows us to link changes in plate motions with well-documented regional tectonic events recorded in basins along the major rift systems and to explain the formation of the enigmatic pre-salt sag basins of the central South Atlantic in the context of a multidirection, multi-velocity plate kinematic history.

\section{Plate reconstructions: data, regional elements, and methodology}

We build a spatio-temporal kinematic framework of relative motions between rigid lithospheric plates based on the inventory of continental rifts, published and unpublished data from the conjugate passive margins and information from oceanic spreading in the South Atlantic. We utilise the interactive, open-source plate kinematic modelling software GPlates (http://www.gplates.org) as an integration platform and the Generic Mapping Tools (http://gmt.soest.hawaii.edu; Wessel and Smith, 1998) to generate our palaeo-tectonic reconstructions (see Figs. 13-21 and the Supplement). Highresolution vectorgraphics of our reconstructions along with the plate model and geospatial data for use in GPlates are available in the Supplement as well as on the Internet at http://datahub.io/en/dataset/southatlanticrift.

\subsection{Absolute plate motion model and timescale}

The plate kinematic model is built on a hybrid absolute plate motion model with a moving hotspot reference frame back to $100 \mathrm{Ma}$ and an adjusted palaeomagnetic absolute reference frame for times before $100 \mathrm{Ma}$ (Torsvik et al., 2008). Global plate motion models are based on magnetic polarity timescales to temporarily constrain plate motions using seafloor-spreading magnetic anomalies (e.g. Seton et al., 2012; Müller et al., 2008). Here, we use the geomagnetic polarity timescale by Gee and Kent (2007, hereafter called GeeK07) which places the young end of magnetic polarity chron M0 at 120.6 Ma and the base of M0r at $121 \mathrm{Ma}$. Agreement across various incarnations of geological timescales exists that the base of magnetic polarity chron M0r represents the Barremian-Aptian boundary (e.g. Ogg and Hinnov, 2012; He et al., 2008; Channell et al., 2000, and references therein). However, considerable debate is ongoing about the absolute age of of the base of M0r, with proposed ages falling in two camps, one around $121 \mathrm{Ma}$ (e.g. He et al., 2008; Gee and Kent, 2007; Berggren et al., 1995) and a second one around 125-126 Ma (Ogg and Hinnov, 2012; Gradstein et al., 2004). Both choices affect the absolute ages of the different pre-Aptian stratigraphic stages as magnetostratigraphy is used to provide a framework for biostratigraphic events. Our preference of using the 121.0 Ma of Gee and Kent (2007) as the base for M0r is based on the arguments put forward by $\mathrm{He}$ et al. (2008) and on a review of global seafloor-spreading velocities, in which an older age assigned to the base of M0r of 125.0 Ma (Gradstein et al., 2004) would 


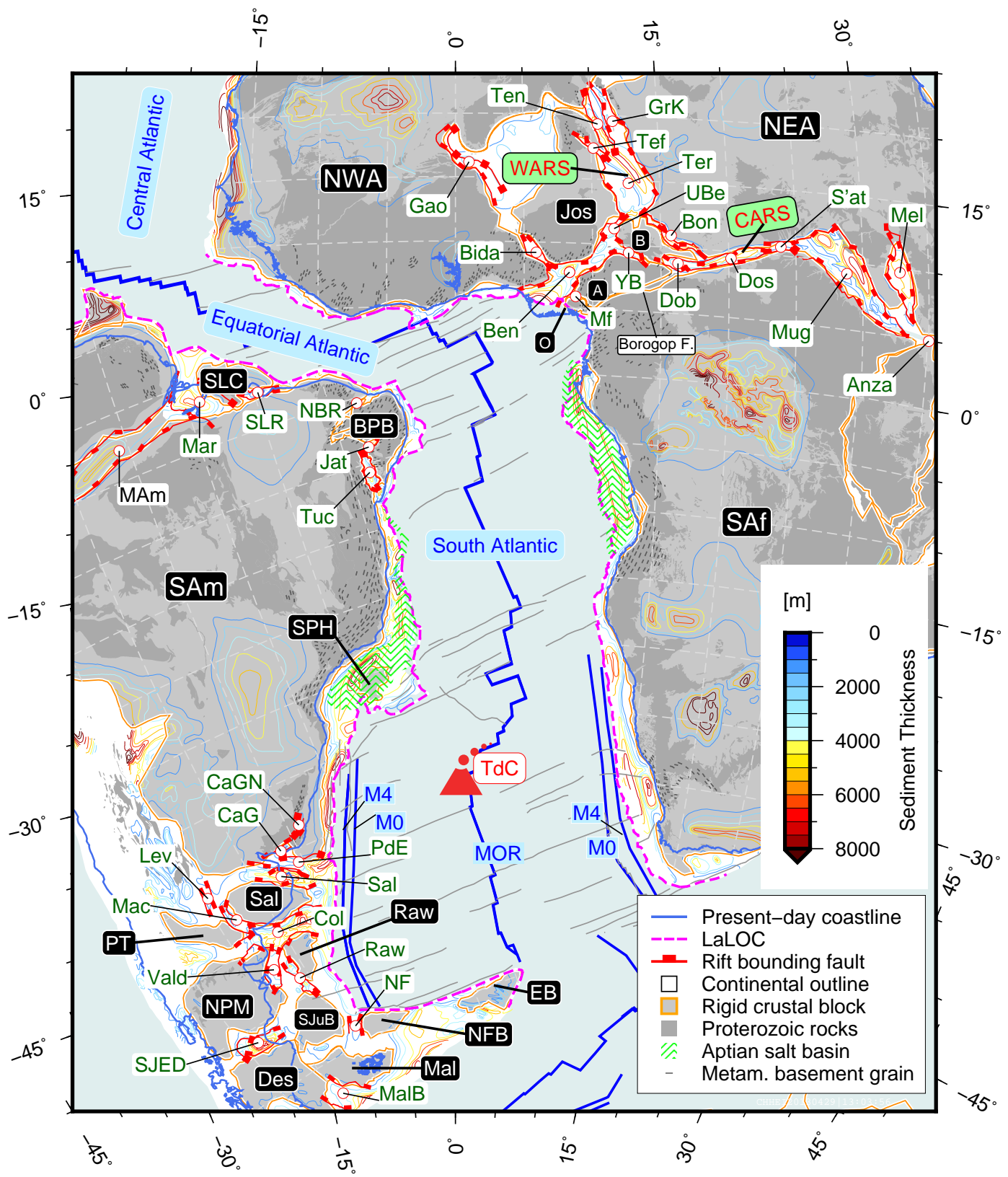

Fig. 1. Rigid crustal blocks, Jurassic-Cretaceous rift structures, and sediment isopachs, reconstructed to 83.5 Ma position (magnetic anomaly chron C34y) with Africa held fixed in present coordinates using the rotation poles of Nürnberg and Müller (1991). Proterozoic rocks are based on United States Geological Survey (2012), metamorphic basement grain as thin white lines (Exxon Production Research Company, 1985). Oceanic fracture zones are shown as grey lines. Tristan da Cuñha hotspot (TdC) indicated by volcano symbol. Rigid crustal blocks denoted as black boxes, rift basins outlined by red fault symbols and denoted in green font and white boxes. Abbreviations: A - Adamaoua Highlands/Benue Microplate; B - Bongor Block; Ben - Benue Trough; BPB - Borborema Province Block; Bida - Bida Basin; Bon - Bongor Trough; CaG/CaGN - Canelones Graben (Santa Lucia) (north); Col - Colorado rift; Dob - Doba Basin; Des - Deseado Massif in Patagonia; Dos - Doseo Basin; EWB - Maurice Ewing Bank; Gao - Gao Trough; GrK - Grein-Kafra rift; Jat - Jatobá rift; Lev - General Levalle (Leboulaye) rift; Mac - Maccachin rift; MAL - Malvinas Block; Mal - Malvinas Basin; Mar - Maranau rift; Mel - Melut rift; Mf - Mamfe Basin; MOR - South Atlantic mid-oceanic ridge; Mug - Muglad rift; NEA - northeast Africa; NBR - northeast Brazilian rifts; NF - Malvinas Norte/N Falklands; NFB - North Falklands Block; NPM - North Patagonian Massif; NWA - northwest Africa; O - Oban Highlands Block; PAM - Pampean Terrane; PdE - Punta del Este Basin; RAW - Rawson Block; Raw - Rawson rift; SAf - southern Africa; Sal - Salado rift; SAm - South America; SJED - San Jorge Extensional Domain; SJuB - San Julian Block; SLC - São Luis Craton; SLR - São Luis rift; SPH - São Paulo High; Tef - Tefidet rift; Ten - Ténéré rift; Ter - Termit rift; Tuc - Tucano rift; UBe - upper Benue rift; Yola - Yola rift branch; Vald - Valdes rift. Sediment isopachs from Exxon Production Research Company (1985) are shown as thin grey lines. Younger deformation and plates related to rifting of East African Rift System are not shown. Lambert azimuthal equal-area projection centred at $20^{\circ} \mathrm{W} / 12^{\circ} \mathrm{N}$. 
result in significantly higher spreading velocities or larger oceanic crust flux for the pre-M0 oceanic crust (Seton et al., 2009; Gee and Kent, 2007; Cogné and Humler, 2006). Additionally, Stone et al. (2008) report a reversed magnetic polarity for a Cretaceous-aged dike from Pony's Pass quarry on the Falkland Islands dated to $121.3 \pm 1.2 \mathrm{Ma}$ (Ar-Ar dating). This further supports the notion of tying the absolute age of M0r old and base Aptian to closer to 121 Ma than to 125 or $126 \mathrm{Ma}$ as postulated by Ogg (2012); Gradstein et al. (2004).

In pre-seafloor-spreading, continental environments, wellconstrained direct age control for relative plate motions does not exist. Here, stratigraphic information from synrift sequences and subsidence data needs to be converted to absolute ages in a consistent framework. As the correlation between absolute ages and stratigraphic intervals has undergone several major iterations over the past decades, published ages from South American and African rift basins require readjustment. To tie stratigraphic ages to the magnetic polarity timescale predominantly used for global plate kinematic models, we have converted the estimates given by Gradstein et al. (1994, here named Geek07/G94) and Gradstein et al. (2004, Geek07/GTS04) to the GeeK07 polarity chron ages (Fig. 2). We use Geek07/GTS04, which places base Aptian (base M0r old) at $121 \mathrm{Ma}$ (Fig. 2).

For published data we have converted both stratigraphic and numerical ages to the new hybrid timescale. A particular example of large differences in absolute ages is the publications by Genik $(1993,1992)$ which are based on the EXXON 1988 timescale (Fig. 2; Haq et al., 1987). Here, the base Cretaceous is given as $\approx 133 \mathrm{Ma}$, whereas the recent GTS timescales (Gradstein et al., 2004) as well as our hybrid timescale place the base Cretaceous between $144.2 \pm 2.5$ and 142.42 Ma, respectively. Issues pertaining to correlate biostratigraphic zonations across different basins further complicate the conversion between stratigraphic and absolute ages regionally (e.g. Chaboureau et al., in press; Poropat and Colin, 2012).

\subsection{Continental intraplate deformation}

Deformation between rigid continental plates has to adhere to the basic rules of plate tectonics and can be expressed as relative rotations between a conjugate plate pair for any given time (Dunbar and Sawyer, 1987). Depending on data coverage and quality, a hierarchical plate model can be assembled from this information (e.g. Ross and Scotese, 1988). In preseafloor-spreading environments, the quantification of horizontal deformation on the regional scale is complicated as discrete time markers, such as oceanic magnetic anomalies, or clear structural features, such as oceanic fracture zones, are lacking. However, rift infill, faulting and post-rift subsidence allow - within reasonable bounds - quantifying the amount of horizontal deformation (e.g. White, 1989; Gibbs, 1984; Le Pichon and Sibuet, 1981). We assume that a significant amount of horizontal displacement $(>15 \mathrm{~km})$ is pre- served in the geological record either as fold belts (positive topographic features) or fault-bounded sedimentary basins and recognised subsequently. Key elements of our plate kinematic model are a set of lithospheric blocks which are nondeforming during the rifting and break-up of western Gondwana (160-85 Ma; Fig. 1). These blocks are delineated using first-order structures, such as main basin-bounding faults, thrust belts or large gradients in reported sediment thickness, indicative of subsurface faulting, in conjunction with potential field and published data. The delineation of these blocks is described in detail in later parts of this manuscript.

We then construct a relative plate motion model based on published data to constrain the timing, direction, and accumulated strain in intraplate deformation zones. This information is augmented with interpreted tectonic lineaments and kinematic indicators (faults, strike-slip zones) from various publications (e.g. Matos, 2000; Genik, 1993; Matos, 1992; Genik, 1992; Exxon Production Research Company, 1985) as well as potential field data from publicly available sources (Andersen et al., 2010; Sandwell and Smith, 2009; Maus et al., 2007) to further refine rigid-block and deforming-zone outlines. Stage rotations were derived by identifying the predominant structural grain and choosing an appropriate rotation pole which allows plate motions to let relative displacement occur so that the inferred kinematics from strain markers along the whole deforming zone (e.g. WARS/CARS) are satisfied. The amount of relative horizontal displacement was then implemented by visual fitting, using published data, and by computed extension estimates, using total sediment thickness.

Sediment thickness can serve as a proxy for horizontal extension in rift basins which have experienced a single phase of crustal extension. Here, we calculate total tectonic subsidence (TTS; Sawyer, 1985) by applying an isostatic correction for varying sediment densities (Sykes, 1996) to the gridded total sediment thickness (Exxon Production Research Company, 1985). Extension factors based on total tectonic subsidence, assuming Airy isostasy throughout the rifting process and not accounting for flexural rigidity, can be computed along a set of parallel profiles across a rift basin, oriented parallel to the main extension direction using the empirical relationship of Le Pichon and Sibuet (1981):

$\mathrm{TTS}=7.83\left(1-\frac{1}{\beta}\right)$

$\gamma=\frac{\mathrm{TTS}}{7.83}$

where $\gamma=1-\frac{1}{\beta}$ and $\beta$ is the stretch factor. It has been shown that this method allows one to compute an upper bound for extension factors in rift basins, in accordance with results from other methods (Barr, 1985; Heine et al., 2008). Values obtained using this methodology are likely to overestimate actual extension estimates, and main uncertainties 


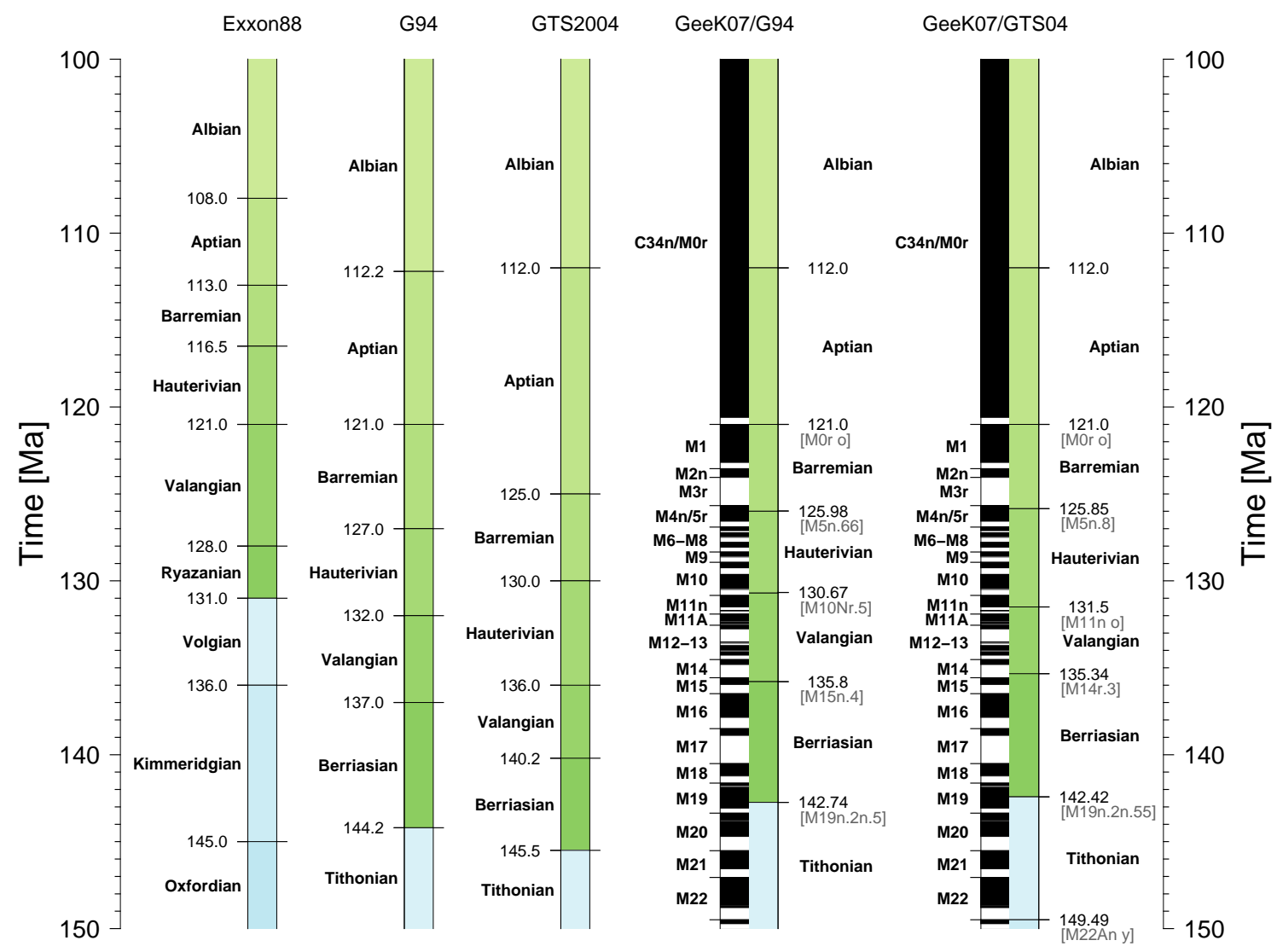

Fig. 2. Comparison of the timescales used in publications related to the South Atlantic marginal basins and the African intraplate basins. GeeK07 is Gee and Kent (2007), Exxon88 is Haq et al. (1987), G94 is Gradstein et al. (1994) and GTS2004 is Gradstein et al. (2004). GeeK07+GTS04 and GeeK07+G94 show magnetic polarity timescale with stratigraphic intervals from GTS04 and G94, respectively, adjusted to tie points annotated on the right hand side of the stratigraphic columns (grey font), where ${ }^{*} \mathrm{~N}$ indicates the relative position from the base of the chron (e.g base Barremian at $125.85 \mathrm{Ma}$ - base M4n young).

in this approach are input sediment thickness and the estimated sediment compaction curves along with the assumption that a single rift phase created the basin. We have applied this methodology for some of the major rift basins (Muglad/Melut; Doba/Doseo/Bongor; Termit/Ténéré/GreinKafra; Gao; Salado; Colorado; see Table 1 and the Supplement) to constrain the amount of rift-related displacement. We assume the bulk of the sediment thickness was accumulated during a single rift phase. However, it is known that both CARS and WARS experienced at least one younger phase of mild rifting and subsequent reactivation which has affected the total sediment thickness (e.g. Genik, 1992; Guiraud et al., 2005) and hence will affect the total amount of extension computed using this method. The extension estimates extracted from individual rift segments are implemented by considering the general kinematics of the whole rift system, as individual rift segments can open obliquely and their margins are not necessarily oriented orthogonally to the stage pole small circles.

Figure 3 shows estimates for a set of parallel profiles across the Termit Basin, orthogonal to the main basin axis, ranging between ca. 50 and $100 \mathrm{~km}$. Where possible, these estimates for extension were verified using published data (Table 1). Due to the inherent lack of precise kinematic and temporal markers during continental deformation and insufficient data, we only describe continental deformation by a single-stage rotation (Table 2, Figs. 6 and 7).

\subsection{Passive margins and oceanic domain}

A wealth of crustal-scale seismic data covering the conjugate South Atlantic margins, both from industry and academic projects, have been published (e.g. Blaich et al., 2011; Unternehr et al., 2010; Greenroyd et al., 2007; Franke et al., 2007, 2006; Contrucci et al., 2004; Mohriak and Rosendahl, 2003; Cainelli and Mohriak, 1999; Rosendahl and GroschelBecker, 1999). We made use of these data to redefine the location of the continent-ocean boundary (COB) in conjunction with proprietary industry long offset reflection seismic data (such as the ION GXT CongoSPAN lines, http://www. iongeo.com/Data_Library/Africa/CongoSPAN/) as well as 
Table 1. Deformation estimates used for major intraplate deformation zones. "Computed" extension is based on the our method as described in Sect. 2 and represents a maximum estimate as it is based on total sediment thickness, always measured orthogonal to major basin/rift axis. "Implemented" deformation is actual displacement as implemented in plate kinematic model. Integers in column "Deforming zone" refer to plate circuit (Fig. 9); abbreviations refer to plate pairs. $\perp$ : extension measured orthogonal to long rift/basin axis; sc: along small circle around corresponding stage pole.

\begin{tabular}{|c|c|c|c|c|c|}
\hline $\begin{array}{l}\text { Deforming } \\
\text { zone }\end{array}$ & $\begin{array}{l}\text { Basin } \\
\text { names }\end{array}$ & Published & $\begin{array}{l}\text { Extension }[\mathrm{km}] \\
\text { Computed }\end{array}$ & Implemented & $\begin{array}{l}\text { Syn-rift duration } \\
\text { [Myrs] }\end{array}$ \\
\hline \multicolumn{6}{|c|}{ CARS - Central African Rift System } \\
\hline $2-\mathrm{BON}-\mathrm{NEA}$ & Bongor/Doba basins & & $\begin{array}{l}31 \mathrm{~km} \\
\text { (Bongor, } \perp \text { ), } \\
20 \mathrm{~km}(\text { Doba, } \perp \text { ) }\end{array}$ & $\begin{array}{l}57 \mathrm{~km} \text { for Doba } \\
\text { Bongor basins } \\
\& \text { comb. }(\mathrm{sc})\end{array}$ & $140-100 \mathrm{Ma}$ \\
\hline 4 JOS-NWA & Bida/Gao/Iullemmeden & $(?)$ & $\begin{array}{l}28 \mathrm{~km} \\
\text { (Bida/Iullemmeden, max.) }\end{array}$ & $\begin{array}{l}15-20 \mathrm{~km} \\
\text { (Gao Trough, sc) }\end{array}$ & $135-110 \mathrm{Ma}$ \\
\hline JOS | BEN & (Central) Benue Trough & & $61 \mathrm{~km}(\max )$. & $36 \mathrm{~km} \perp, 40 \mathrm{~km}(\mathrm{sc})$ & $140-110 \mathrm{Ma}$ \\
\hline \multicolumn{6}{|l|}{ South America } \\
\hline 5 - SAL-SAm & Salado/Punta Del Este basins & $(?)$ & 65 km (max.) & $45 \mathrm{~km}(\mathrm{sc}, \perp)$ & $140-120.6 \mathrm{Ma}$ \\
\hline 6 - NPM-SAL & Colorado Basin & $45 \mathrm{~km}^{\mathrm{b}}$ & $106 \mathrm{~km}$ (max.) & $40 \mathrm{~km}(\mathrm{sc}, \perp)$ & $140-120.6 \mathrm{Ma}$ \\
\hline
\end{tabular}

proprietary and public potential field data and models (e.g. Sandwell and Smith, 2009; Maus et al., 2007).

As some segments of this conjugate passive-margin system show evidence of hyperextended margins as well as for extensive volcanism and associated seaward-dipping reflector sequences (SDRs), we introduce the "landward limit of the oceanic crust" (LaLOC) as a boundary which delimits relatively homogeneous oceanic crust oceanward from either extended continental crust or exhumed continental lithospheric mantle landward or SDRs where an interpretation of the Moho and/or the extent of continental crust is not possible. This definition has proven to be useful in areas where a classic COB cannot easily be defined, such as in the distal parts of the Kwanza Basin offshore Angola (Unternehr et al., 2010), the oceanward boundary of the Santos Basin (Zalán et al., 2011) or along the conjugate magmatic margins of the southern South Atlantic.

Area balancing of the top basement and Moho horizons has been used on published crustal-scale passive-margin cross sections by Blaich et al. (2011) to restore the initial pre- deformation stage of the margin, assuming no out-of-plane motions and constant area. Initial crustal thickness estimates are based on the CRUST2 crustal thickness model (Laske, 2004). While these assumptions simplify the actual margin architecture and do not account for alteration of crustal thickness during extension, Fig. 4 shows that which of three different limits of the extent of continental crust (minimum, COB based on Blaich et al., 2011, and LaLOC) is chosen only has relatively limited effects on the width of the restored margin.

Considering the plate-scale approach of this study and inherent uncertainties in the interpretation of sub-salt structures on seismic data, these estimates provide valid tie points for a fit reconstruction. The resulting fit matches well with the estimates of Chang et al. (1992) for pre-extensional margin geometry for the Brazilian margin (compare Figs. 13-21). Area balancing of the continental basement (top basement to Moho) results in stretching estimates ranging from 2.6 to 3.3 (Fig. 4). Some of the margin cross sections do not cover the full margin width from unstretched continental to oceanic crust (e.g. north Gabon and Orange sections). Here, we allow 
a)

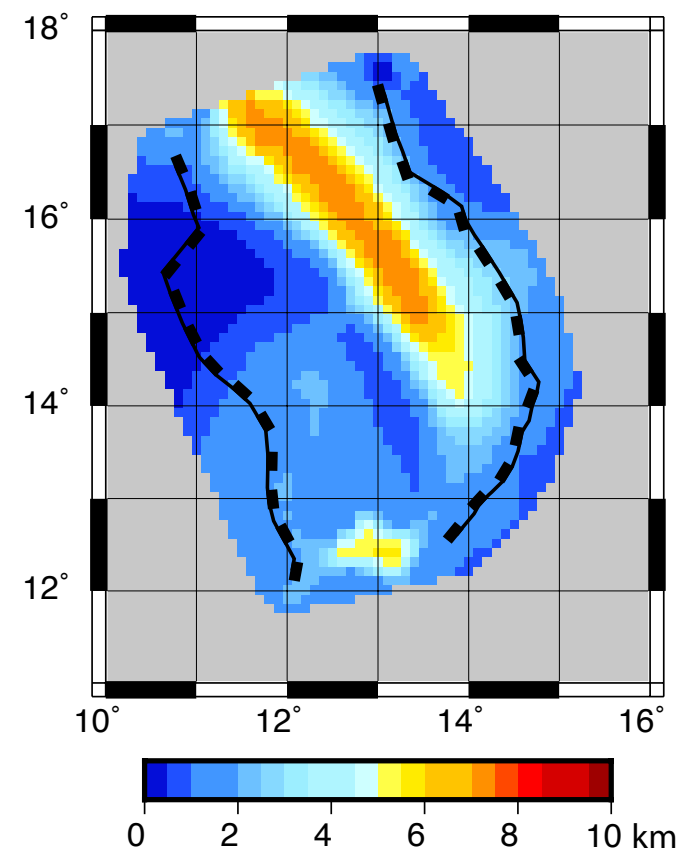

b)

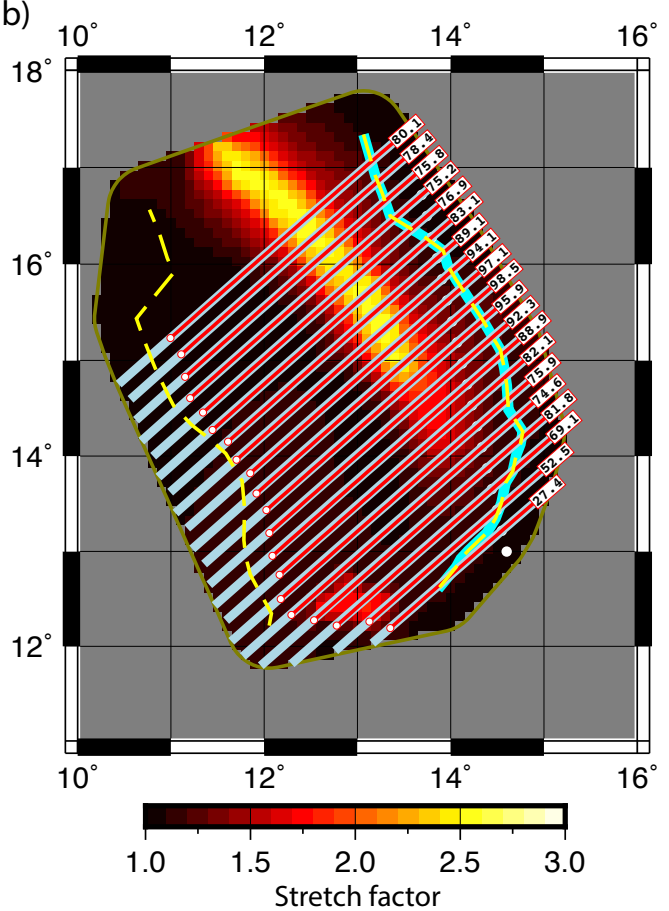

Fig. 3. Computed extension for the Termit Basin in Chad based on total sediment thickness. (a) sediment thickness based on Exxon Production Research Company (1985); (b) stretching factor grid and computed amount of extension using the method of Le Pichon and Sibuet (1981) - see text for details. Estimates of horizontal extension for the Termit Basin. Cyan-coloured lines are main rift bounding faults, light-blue lines are profile lines with original length, red lines are restored length based on extension estimates from sediment thickness. Numbers indicate individual amount of computed extension along each line in kilometres. for a slight overlap in the fit reconstruction. We have also carried out an extensive regional interpretation of Moho, top basement and base salt reflectors on ION GXT CongoSPAN seismic data to verify results from areal balancing of the published data.

The conjugate South Atlantic passive margins are predominantly non-volcanic in the northern and central part and volcanic south of the conjugate Santos/Benguela segment (e.g Blaich et al., 2011; Moulin et al., 2009). In the volcanic margin segments, the delineation of the extent of stretched continental crust is hampered by thick SDRs and volcanic buildups. Previous workers have associated the landward termination of the SDRs along the South American and southwestern African continental margins with the "G" magnetic anomaly and a prominent positive "large magnetic anomaly (LMA)" delineating the boundary between a transitional crust domain of mixed extended and heavily intruded continental crust (e.g. Blaich et al., 2011; Moulin et al., 2009; Gladczenko et al., 1997; Rabinowitz and LaBrecque, 1979). We follow previous workers in magmatically dominated margin segments by using the seaward edge of SDRs and transition to normal oceanic spreading for the location of our LaLOC.

Published stratigraphic data from the margins is integrated to constrain the onset and dynamics of rifting along with possible extensional phases (e.g. Karner and Gambôa, 2007). Little publicly available data from distal and deeper parts of the margins exist which could further constrain the spatiotemporal patterns of the late syn-rift subsidence.

To quantify oceanic spreading and relative plate motions between the South American and southern African plates before the Cretaceous Normal Polarity Superchron (CNPS, 83.5-120.6 Ma) we use a pick database compiled by the EarthByte Group at the University of Sydney, forming the base for the digital ocean floor age grid (Seton et al., 2012).

We combine these data with the interpretations of Max et al. (1999) and Moulin et al. (2009) and the WDMAM gridded magnetic data (Maus et al., 2007) to create a set of isochrons for anomaly chrons M7n young (127.23 Ma), M4 old (126.57 Ma), M2 old (124.05 Ma), and M0r young (120.6 Ma) using the magnetic polarity timescale of Gee and Kent (2007). M sequence anomalies from M11 to M8 are only reported for the African side (Rabinowitz and LaBrecque, 1979), whereas M7 has been identified on both conjugate abyssal plains close to the LaLOC (Moulin et al., 2009; Rabinowitz and LaBrecque, 1979). Oceanic spreading and relative plate velocities during the CNPS are linearly interpolated, with plate motion paths only adjusted to follow prominent fracture zones in the equatorial and South Atlantic.

\subsection{Reconstruction methodology}

Deforming tectonic elements and their tectono-stratigraphic evolution from the South Atlantic, equatorial Atlantic, and intraplate rift systems in Africa and South America such 




Fig. 4. Margin cross sections and area balancing based on Blaich et al. (2009, 2011), and our synthesised data based on depth-migrated and gridded CongoSPAN data along various segments of the conjugate South Atlantic margins. $\mathrm{T}_{\mathrm{r}}$ : restored thickness. Extent of continental crust used for area balancing: L - LaLOC (maximum estimate, landward limit oceanic crust); M - minimum estimate (conservative); B - COB based on Blaich et al. (2009, 2011). Note that our interpretation of the CongoSPAN data (CS Grid north and south sections) includes a zone where no Moho could be identified on seismic data, which is here tentatively interpreted as exhumed mantle. Further note the difference in length of the Colorado Basin section. The profile data are available as plain text files at http://datahub.io/en/dataset/southatlanticrift.

as intraplate basins, fault zones or passive-margin segments are synthesised using available published and non-published data to constructed a hierarchical tectonic model (Fig. 9). Starting with the African intraplate rifts, we iteratively refine the individual stage poles and fit reconstructions based on published estimates and our own computations, ensuring that the implied kinematic histories for a plate pair do not violate geological and kinematic constraints in adjacent deforming domains. For example, the choice of a rotation pole and rigid plate geometries which describe the deformation between our southern African and NE African plates to explain the opening of the Muglad Basin is also required to match 
deformation along the western end of the Central African shear zone in the Doba and Bongor basins (e.g. Fig. 6).

After restoring the intra-African plate deformation, we iteratively refine the tight-fit reconstruction of the South American Plate against the NW African and southern African plates by reconstructing our restored profiles (Fig. 4), Chang et al. (1992)'s restored COB, and key structural elements.

Subsequently, remaining basin elements and rigid blocks of the Patagonian extensional domain (Salado, North Patagonian Massif, Deseado, Rawson, San Julian and Falkland blocks) are restored to pre-rift/deformation stage and integrated to achieve a full-fit reconstruction for the latest Jurassic/Early Cretaceous time in the southern South Atlantic (cf. Fig. 13).

\section{Tectonic elements: rigid blocks and deforming domains}

Burke and Dewey (1974) pointed out that Africa did not behave as a single rigid plate during Cretaceous rifting of the South Atlantic. They divided Africa into two plates separated along the Benue Trough-Termit Graben (WARS in Fig. 1). Subsequent work identified another rift system trending to the east from the Benue area (Genik, 1992; Fairhead, 1988, CARS in Fig. 1).

There is less evidence of Late Jurassic/Early Cretaceous deformation in South America, although several continentscale strike-slip zones have been postulated (see Moulin et al., 2009, and references therein). We define four major plate boundary zones and extensional domains: the Central African (CARS), West African (WARS), South Atlantic (SARS), and Equatorial Atlantic (EqRS) Rift Systems. We include a "Patagonian extensional domain", composed of Late Jurassic/Early Cretaceous-aged basins and rigid blocks in southern South America in our definition of the SARS (Fig. 1). From these four extensional domains, only the SARS and EqRS transitioned from rifting to breaking up, creating the equatorial and South Atlantic Ocean basins. In the next sections we review timing, kinematics, type and amount of deformation for each of these domains.

\subsection{Africa}

The West African and Central African Rift Systems (Figs. 1 and 5; WARS \& CARS) and associated depocentres document extensional deformation between the following continental lithospheric sub-plates in Africa, starting in the latest Jurassic/Early Cretaceous:

1. Northwest Africa (NWA), bound to the east by the WARS/east Niger rift and delimited by the central and equatorial Atlantic continental margins to the west and south, respectively (e.g. Guiraud et al., 2005; Burke et al., 2003; Genik, 1992; Fairhead, 1988).
2. Nubian/northeast Africa (NEA), bound by the WARS to the west, and the CARS/central African shear zone to the south (e.g. Bosworth, 1992; Genik, 1992; Popoff, 1988; Schull, 1988), (e.g. Browne et al., 1985; Browne and Fairhead, 1983). To the east, northeast and north this block is delimited by the east African rift, the Red Sea and the Mediterranean margin, respectively.

3. Southern Africa (SAf) is separated from NEA through the CARS and bound by the East African Rift System to the east and southeast. Its southern and western margins are defined by the South Atlantic continental passive margins (e.g. Nürnberg and Müller, 1991; Unternehr et al., 1988).

4. The Jos Sub-plate, named after the Jos Plateau in Nigeria, is situated between NWA, NEA and the Benue Trough region. We define this plate along its western margin by a graben system of Early Cretaceous age in the Gao Trough/Graben area in Mali and the Bida/Nupe basins in NW Nigeria (Guiraud et al., 2005; Guiraud and Maurin, 1992; Genik, 1992; Adeniyi, 1984; Cratchley et al., 1984; Wright, 1968). The Benue Trough and WARS delimit the the Jos Sub-plate to the south and east. As the northern boundary we chose a diffuse zone through the Iullemmeden/Sokoto Basin and Airr Massif, linking the WARS with the Gao Trough area (e.g. Guiraud et al., 2005; Genik, 1992; Cratchley et al., 1984).

5. The Adamaoua (Benue), Bongor and Oban Highlands microplates (Fig. 1) are situated south of the Benue Trough and north of the sinistral Borogop fault zone. This fault zone defines the western end of the CARS as it enters the Adamaoua region of Cameroon (Genik, 1992; Benkhelil, 1982; Burke and Dewey, 1974). Together with the Benue Trough in the north, the Atlantic margin in the west and the Doba, Bongor, BormuMassenya basins, it encompasses a relatively small cratonic region in Nigeria/Cameroon which has been termed "Benue Sub-plate" by previous workers (e.g. Moulin et al., 2009; Torsvik et al., 2009). The Yola rift branch (YB in Fig. 1) of the Benue Trough as well as the Mamfe Basin (Mf) indicate significant crustal thinning (Fairhead et al., 1991; Stuart et al., 1985) justifying a subdivision of this region into the two blocks.

The CARS and WARS are distinct from earlier Karooaged rift systems which mainly affected the eastern and southern parts of Africa (Bumby and Guiraud, 2005; Catuneanu et al., 2005) but have presumably formed along pre-existing older tectonic lineaments of pan-African age (Daly et al., 1989). 


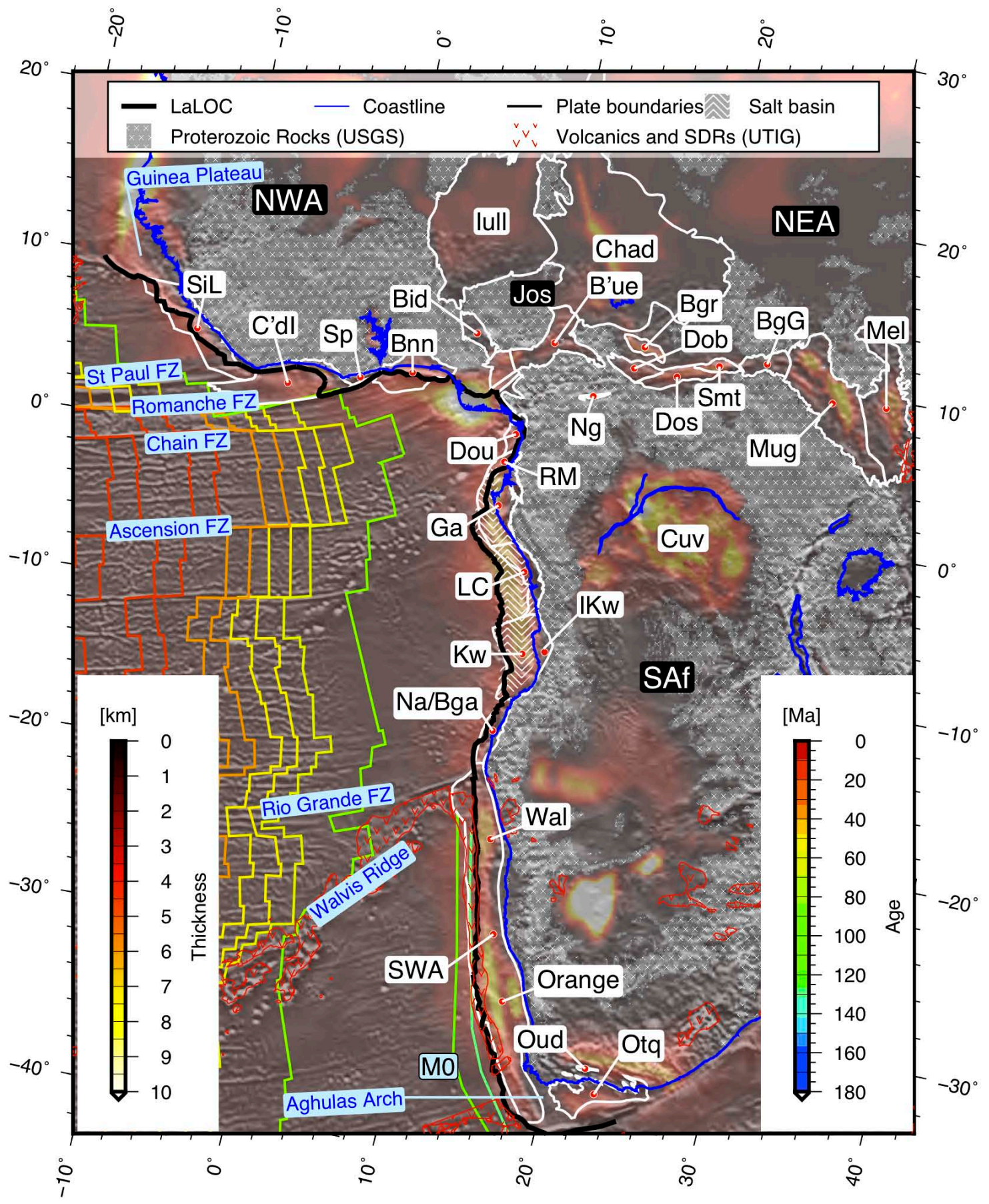

Fig. 5. Oblique Mercator map of present-day Africa, with onshore topography (ETOPO1; Amante and Eakins, 2009), offshore free-air gravity (Sandwell and Smith, 2009), both greyscale, and gridded sediment thickness (Exxon Production Research Company, 1985) superimposed. Map legend: LaLOC - landward limit of oceanic crust, Proterozoic rocks and Mesozoic extrusive rocks based on United States Geological Survey (2012). Seaward-dipping reflectors (SDRs) based on UTIG PLATES open data (https://www.ig.utexas.edu/research/projects/plates/ data.htm). White polygons indicate sedimentary basins (N to S): SiL - Sierra Leone marginal; C'dI - Côte d'Ivorie marginal; Sp - Saltpond; Bnn - Benin; Bid - Bida; Iull - Iullememmden; Chad - Chad Basin; B'ue - Benue Trough; Bgr - Bongor Trough; Dob - Doba; Dos - Doseo; BgG - Banggara Graben; Mel - Melut; Mug - Muglad; Smt - Salamat; Ng - Ngaoundere; Dou - Douala; RM - Rio Muni; Ga - Gabon coastal; Cuv - Cuvette central; LC - lower Congo; Kw - Kwanza/Cuanza; IKw - inner Kwanza; Na/Bga - Namibe/Benguela; Wal - Walvis; SWA - southwest African marginal; Orange - Orange; Oud - Oudtshoorn; Otq - Outeniqua. Fz: oceanic fracture zone. Coloured lines are oceanic isochrons from Müller et al. (2008); M0 - M0 magnetic anomaly (120.6 ma). Plates and sub-plates: NWA - northwest Africa; NUB - Nubia/northeast Africa; JOS - Jos Plateau sub-plate; and SAf - austral Africa. Origin of map projection at $10^{\circ} \mathrm{S}, 5^{\circ} \mathrm{W}$; azimuth of oblique equator $80^{\circ}$. 


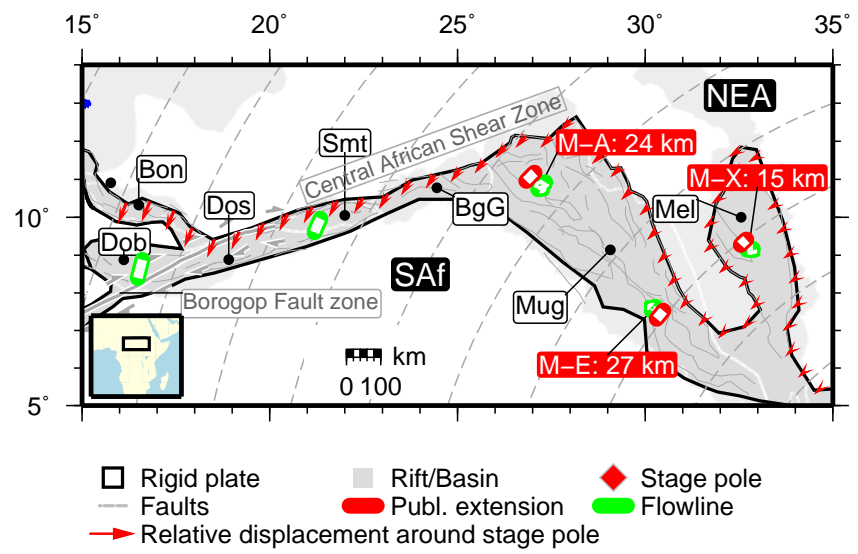

Fig. 6. Stage pole rotation and associated small circles (dashed grey lines) at $2^{\circ}$ spacing for $145-110 \mathrm{Ma}$ interval for the Central African Rift System (CARS) and associated relative plate motions at $110 \mathrm{Ma}$. Main rigid plates: SAf - southern Africa; NEA - northeastern Africa. Main basins and rifts: Bgr - Bongor Basin; Dob - Doba; Dos - Doseo; Smt - Salamat; BgG - Bangara Graben; Mug - Muglad; Mel - Melut; Anza - Anza rift. Red boxes and text indicate published profiles for Melut and Muglad basins and estimated extension values based on McHargue et al. (1992): M-A - profile A-A'; M-E - profile E-E'; M-X - profile X-X'. Vectors shown on map only show relative motions, white core of published profiles and of green flowlines indicates actual amount of extension in $\mathrm{km}$. These are $\approx 24 \mathrm{~km}$ for profile $\mathrm{M}-\mathrm{A}, \approx 27 \mathrm{~km}$ for profile $\mathrm{M}-\mathrm{E}$ and $\approx 15 \mathrm{~km}$ for profile $\mathrm{M}-\mathrm{X}$ during the intial basin-forming phase F1(red; McHargue et al., 1992), with modelled extension of $\approx 30 \mathrm{~km}, \approx 17 \mathrm{~km}$, and $\approx 17 \mathrm{~km}$ (green), respectively. Red vectors indicate angular displacement of rigid block around stage pole back to fit reconstruction position.

\subsubsection{Central African Rift System (CARS)}

The eastern part of the CARS, consisting of the Sudanese Melut, Muglad and Bagarra basins, forms a zone a few hundred kilometres wide with localised NW-SE-striking sedimentary basins which are sharply delimited to the north by the so-called Central African shear zone (Bosworth, 1992; McHargue et al., 1992; Schull, 1988; Exxon Production Research Company, 1985; Browne and Fairhead, 1983). Subsurface structures indicate NNW/NW-trending main basinbounding lineaments and crustal thinning with up to $13 \mathrm{~km}$ of Late Jurassic/Early Cretaceous-Tertiary sediments (Fig. 5; Mohamed et al., 2001; McHargue et al., 1992; Schull, 1988; Browne et al., 1985; Browne and Fairhead, 1983). Published values for crustal extension in the Muglad and Melut basins in Sudan range between 22-48 km (Browne and Fairhead, 1983), 15-27 km (McHargue et al., 1992) in the SW-NE direction and $\beta=1.61$ for an initial crustal thickness of $35 \mathrm{~km}$, resulting in $56 \mathrm{~km}$ of extension (Mohamed et al., 2001) with a first post-rift phase commencing in the Albian $(\approx 110 \mathrm{Ma}$; McHargue et al., 1992).
Dextral transtensional motions along the western part of the CARS during the Early Cretaceous created the Salamat, Doseo and Doba basins (Fig. 5; Bosworth, 1992; McHargue et al., 1992; Schull, 1988). These depocentres locally contain more than $8 \mathrm{~km}$ of Early Cretaceous to Tertiary sediments and are bound by steeply dipping faults, indicative of pull-apart/transtensional kinematics for the basin opening (Fig. 5; Genik, 1993; Maurin and Guiraud, 1993; Binks and Fairhead, 1992; Genik, 1992; Guiraud et al., 1992; Exxon Production Research Company, 1985; Browne and Fairhead, 1983). The structural inventory of these basins largely follows old pan-African-aged lineaments and has been reactivated during the Santonian compressive event (Guiraud et al., 2005; Janssen et al., 1995; Maurin and Guiraud, 1993; Genik, 1992; Daly et al., 1989).

The Borogop Fault (Figs. 1 and 6) defines the western part of the Central African shear zone and enters the cratonic area of the Adamaoua uplift in Cameroon, where smaller, Early Cretaceous-aged basins such as the Ngaoundere rift are located (Fig. 5; Maurin and Guiraud, 1993; Plomerová et al., 1993; Guiraud et al., 1992; Fairhead and Binks, 1991). The reported total dextral displacement is estimated to be 40 $50 \mathrm{~km}$ based on basement outcrops and around $35 \mathrm{~km}$ in the Doseo Basin (Genik, 1992; Daly et al., 1989).

We have implemented a compounded total extension between 20 and $45 \mathrm{~km}$, between 140 and $110 \mathrm{Ma}$ (early Albian) in the Muglad and Melut basins, generated through rotation of the SAf Block counterclockwise relative to NEA (Fig. 6, Table 1). The stage pole is located in the Somali Basin, south of the Anza rift/Lamu Embayment, resulting in moderate extension $(\approx 10 \mathrm{~km})$ in the northern Anza rift in Kenya, which is supported by observations of faulting of Early Cretaceous age (Morley et al., 1999; Reeves et al., 1987). The chosen stage rotation results in estimates of distributed oblique extension/sinistral transtension along the western end of the CARS in the Bongor, Doba and Doseo basins. Based on our choice of rigid plates, this stage pole accounts for the opening of the Sudanese, Central African rifts as well as the Bongor Basin.

Transtensional dextral displacement along the Borogop fault zone in our model amounts to $40-45 \mathrm{~km}$ in the Doseo Basin, which is in agreement with the $25-56 \mathrm{~km}$ extension reported from the Sudanese basins (Mohamed et al., 2001; McHargue et al., 1992).

Stage poles and associated small circles for the NEA-SAf rotation are oriented orthogonally to mapped Early Cretaceous extensional fault trends for the Doba and Doseo basins (Genik, 1992), and graben-bounding normal faults in the Sudanese basins (Fig. 6). Other authors have used $70 \mathrm{~km}$ of strike-slip/extension for the CASZ and Sudanese basins, respectively (Moulin et al., 2009), which is about double the amount reported (Genik, 1992; McHargue et al., 1992). Torsvik et al. (2009) model the CARS but do not specify an exact amount of displacement between their southern African and the NE African sub-plates. 


\subsubsection{West African Rift System (WARS)}

The West African/east Niger rift (WARS) extends northward from the eastern Benue Trough region through Chad and Niger towards southern Algeria and Lybia (Fig. 1). The recent Chad Basin is underlain by a series of N-S-trending rift basins, encompassing the Termit Trough, N'Dgel Edgi, Tefidet, Ténéré, and Grein-Kafra basins containing up to $12 \mathrm{~km}$ of Early Cretaceous to Tertiary sediments (Figs. 5 and 3; Guiraud et al., 2005; Guiraud and Maurin, 1992; Genik, 1992; Exxon Production Research Company, 1985). These basins are extensional, asymmetric rifts, initiated through block faulting in the Early Cretaceous, with a dextral strikeslip component reported from the Tefidet region ("Tef" in Fig. 1; Guiraud and Maurin, 1992; Genik, 1992). The infill is minor Palaeozoic to Jurassic pre-rift, non-marine sediments and a succession of non-marine to marine Cretaceous clastics of up to $6 \mathrm{~km}$ thickness with reactivation of the structures during the Santonian (Bumby and Guiraud, 2005; Guiraud et al., 2005; Genik, 1992). Towards the north of the WARS, $\mathrm{N}-\mathrm{S}$-striking fault zones of the El Biod-Gassi Touil High in the Algerian Sahara and associated sediments indicate sinistral transpression during the Early Cretaceous (Guiraud and Maurin, 1992). The main rift development occurred during Phase 3 of Genik (1992) from the Early Cretaceous to top Albian (130-98 Ma) with full rift development by $108 \mathrm{Ma}$ (Genik, 1992, using the EXXON timescale).

Early Cretaceous sedimentation and normal faulting in the Iullemmeden/Sokoto and Bida basins in NW Nigeria and the Gao Trough in Mali indicates that lithospheric extension also affected an area NW of the Jos Sub-plate and further west of the WARS sensu stricto (Guiraud et al., 2005; Obaje et al., 2004; Genik, 1993, 1992; Guiraud and Maurin, 1992; Adeniyi, 1984; Cratchley et al., 1984; Petters, 1981; Wright, 1968). Reported sediment thicknesses here range between 3 and $3.5 \mathrm{~km}$ for the Bida Basin (Obaje et al., 2004, Fig. 5). Our definition of the WARS hence encompasses this area of diffuse lithospheric extension.

Palinspastic restoration of 2-D seismic profiles across the Termit Basin part of the WARS yields extension estimates between 40 and $80 \mathrm{~km}$ (using Moho depths of $26 \mathrm{~km}$; Genik, 1992). Our computed maximum extension estimates for the WARS rift basins using total tectonic subsidences results in a maximum cumulative extension of 90-100 km (Fig. 3, Table 1). We use $70 \mathrm{~km}$ of extension in the Termit Basin region and $60 \mathrm{~km}$ in the Grein-Kafra Basin to accommodate relative motions between the Jos Sub-plate and NEA between base Cretaceous and $110 \mathrm{Ma}$. Fault and sediment isopach trends indicate an E-W to slightly oblique rifting, trending NNW-SSE for the main branch of the WARS. Our stage rotation between NWA and NEA results in oblique, NNE-SSWdirected opening of the WARS (Fig. 7). Other workers have used $130 \mathrm{~km}$ of E-W-directed extension in the south (Termit Basin) and $75 \mathrm{~km}$ for northern parts (Grein/Kafra basins; Torsvik et al., 2009) between $132-84$ Ma or $80 \mathrm{~km}$ of SW-

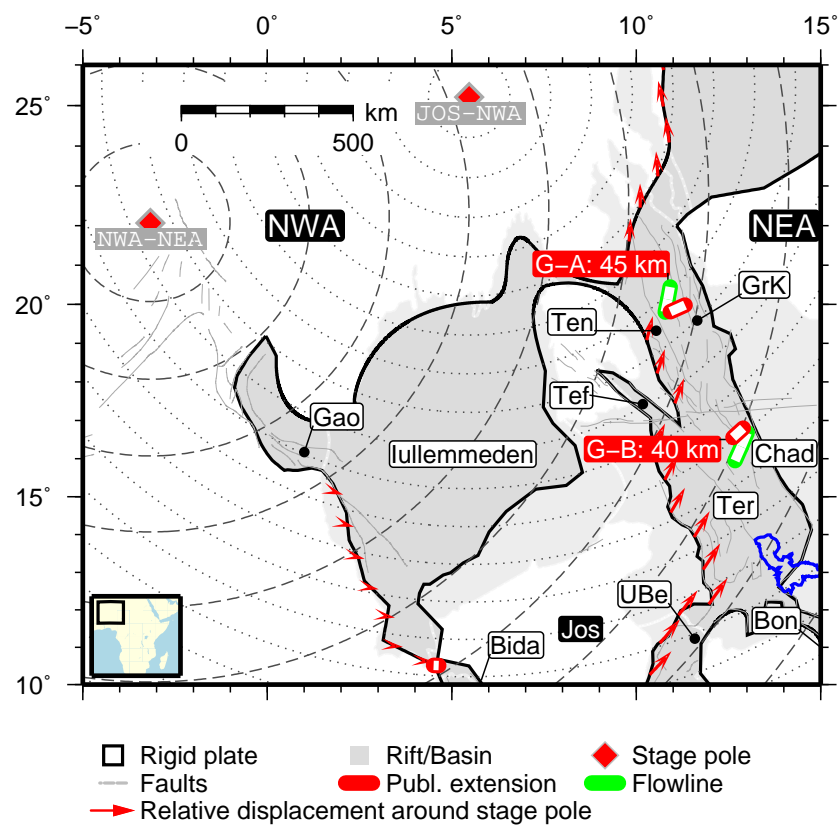

Fig. 7. Stage pole rotation and associated small circles (dashed and stippled grey lines) at $2^{\circ}$ spacing for $145-110 \mathrm{Ma}$ interval for the West African Rift system (WARS) and associated relative plate motions at 110 ma. Main plates: NEA - northeast Africa; NWA - nortwest Africa; Jos - Jos Sub-plate. Main rifts: Gao - Gao Trough; UBe - upper Benue; Ter - Termit; Bgr - Bongor; Tef Tefidet; Ten - Ténéré; GrK - Grein-Kafra. Basins: Chad - Chad Basin; Iullemmeden - Iullemmeden Basin; Bida - Bida Basin. Red boxes and text indicate published profiles for Grein-Kafra and Termit rifts and estimated extension values based on Genik (1992): G-A - profile A-A'; G-B - profile B-B'. Vectors shown on map only show relative motions, white core of published profiles and of green flowlines indicates actual amount of extension in $\mathrm{km}$. These are $\approx 45 \mathrm{~km}$ for profile G-A and $40-80 \mathrm{~km}$ for profile G-B, (red; Genik, 1992), with modelled extension of $\approx 28 \mathrm{~km}$ and $\approx 43 \mathrm{~km}$ (green), respectively. Red vectors indicate angular displacement of rigid block around stage poles back to fit reconstruction position. Vectors northeast of the Grein-Kafra rift indicate possible Early Cretaceous basin-and-swell topography related to strike-slip reactivation of basement structures in southern Lybia based on Guiraud et al. (2005).

NE-directed oblique extension (Moulin et al., 2009). For the Bida (Nupe) Basin/Gao Trough, we estimate that approximately $15 \mathrm{~km}$ of extension occurred between the Jos Subplate and NWA, resulting in a cumulative extension between NWA and NEA of 85-75 km between $143 \mathrm{Ma}$ and $110 \mathrm{Ma}$.

\subsubsection{Benue Trough}

The Benue Trough and associated basins, like the Gongola Trough and the Bornu and Yola basins, are located in the convergence of the WARS and CARS in the junction between the northwest, northeast and southern African plates. The tectonic position makes the Benue Trough susceptible 
to changes in the regional stress field, reflected by a complex structural inventory (Benkhelil, 1989; Popoff, 1988). Sediment thicknesses reach locally more than $10 \mathrm{~km}$, with the oldest outcropping sediments reported as Albian age from anticlines in the upper Benue Trough (Fairhead and Okereke, 1990; Benkhelil, 1989). Subsidence in the Benue Trough commences during Late Jurassic to Barremian as documented by the Bima-1 formation in the upper Benue Trough (Guiraud et al., 2005; Guiraud and Maurin, 1992).

The observed sinistral transtension in the Benue Trough is linked to the opening of the South Atlantic basin and extension in the WARS and CARS (Guiraud et al., 2005; Genik, 1993, 1992; Fairhead and Binks, 1991; Fairhead and Okereke, 1990; Benkhelil, 1989; Popoff, 1988; Benkhelil, 1982; Burke, 1976; Burke and Dewey, 1974). It follows that the onset of rifting and amount of extension in the Benue Trough is largely controlled by the relative motions along the WARS and CARS. Maximum crustal extension estimates based in gravity inversion are $95 \mathrm{~km}, 65 \mathrm{~km}$, and $55 \mathrm{~km}$ in the Benue and Gongola troughs and Yola rift with about $60 \mathrm{~km}$ of sinistral strike-slip (Fairhead and Okereke, 1990; Benkhelil, 1989). Rift activity is reported from the "Aptian (or earlier)" to the Santonian (Fairhead and Okereke, 1990), synchronous with the evolution of the CARS and WARS (Guiraud et al., 2005; Genik, 1992).

We here regard the Benue Trough as the product of differential motions between NWA, NEA and the Adamaoua Microplate which is separated from southern Africa by the Borogop fault zone. Deformation implemented in our model for the WARS and CARS results in $\approx 20 \mathrm{~km}$ of N-S-directed relative extension and about $50 \mathrm{~km}$ of sinistral strike-slip in the Benue Trough between the Early Cretaceous and early Albian.

The Mamfe Basin at the SW end of the Benue Trough separates the Oban Highlands block from the Adamaoua Microplate in the east (Fig. 1). It is conjugate to NE Brazil. Twenty $\mathrm{km}$ of extension are reported for this region which we have restored in our plate model.

\subsection{South America}

The present-day South American continent is composed of a set of Archean and Proterozoic cores which were assembled until the early Palaeozoic, with its southernmost extent defined by the Rio de la Plata Craton (Fig. 8; Pángaro and Ramos, 2012; Almeida et al., 2000). Large parts of South America, in contrast to Africa, show little evidence of significant and well-preserved, large offset (10's of km) intraplate crustal deformation during the Late Jurassic to midCretaceous. In the region extending from the Guyana shield region in the north, through Amazonia and São Francisco down to the Rio de la Plata Craton there are no clearly identifiable sedimentary basins or compressional structures with significant deformation reported in the literature which initiated or became reactivated during this time interval.
The Amazon Basin and the Transbrasiliano lineament have been used as the two major structural elements by various authors to accommodate intraplate deformation of the main South American Plate. Eagles (2007) suggests the Solimões, Amazon and Marajó basins as the location of a temporary, transpressional plate boundary during South and equatorial Atlantic rifting, where a southern South American block is dextrally displaced by $\approx 200 \mathrm{~km}$ against a northern block. The basin is underlain by old lithosphere of the Amazonia Craton ( $\mathrm{Li}$ et al., 2008; Almeida et al., 2000) which experienced one main rifting phase in early Palaeozoic times and subsequent, predominately Palaeozoic sedimentary infill (Fig. 8; da Cruz Cunha et al., 2007; Gonzaga et al., 2000; Matos and Brown, 1992; Nunn and Aires, 1988). It is covered by a thin blanket of Mesozoic and Cenozoic sediments which show mild reactivation with NE-trending reverse faults and minor dextral wrenching along its eastern margin/Foz do Amazon/Marajó Basin during the Late Jurassic to Early Cretaceous (da Cruz Cunha et al., 2007; Costa et al., 2001; Gonzaga et al., 2000). Reactivation affecting the whole Amazon Basin is reported only from the Cenozoic (Azevedo, 1991; Costa et al., 2001). We do not regard this tectonic element as a temporary plate boundary during formation of the South Atlantic.

The continental-scale Transbrasiliano lineament (TBL; Almeida et al., 2000) formed during the PanAfrican/Brasiliano orogenic cycle. It is a potential candidate for a major accommodation zone for intraplate deformation in South America (Feng et al., 2007; Pérez-Gussinyé et al., 2007), however, the amount of accommodated deformation and the exact timing remain elusive (Almeida et al., 2000). Some authors suggest strike-slip motion during the opening of the South Atlantic between 60 and $100 \mathrm{~km}$ along this $3000 \mathrm{~km}$-long, continent-wide shear zone, reaching from NE Brazil down into northern Argentina (Aslanian and Moulin, 2010; Moulin et al., 2009; Fairhead et al., 2007). Along undulating lineaments such as the TBL, any strike-slip motion would have resulted in a succession of restraining and releasing bends (Mann, 2007), creating either compressional or extensional structures in the geological record. For comparison, the reported offset along the Borogop Shear Zone in the Central African Rift System ranges around $40 \mathrm{~km}$ during the Late Jurassic-Early Cretaceous and created a series of deep ( $>6 \mathrm{~km}$ ) intracontinental basins (Doba, Doseo, Salamat - Fig. 5; Genik, 1992; McHargue et al., 1992). While we do not refute evidence of reactivation of the TBL during the opening of the South Atlantic, published geological and geophysical data do not provide convincing support for the existence of a plate boundary separating the South American platform along the Transbrasiliano lineament during the opening of the South Atlantic.

In southern Brazil, previous authors have argued for the Carboniferous Paraná Basin being the location for a large NW-SE-striking intracontinental shear zone to close the "underfit" problems in the southern part of the South Atlantic 


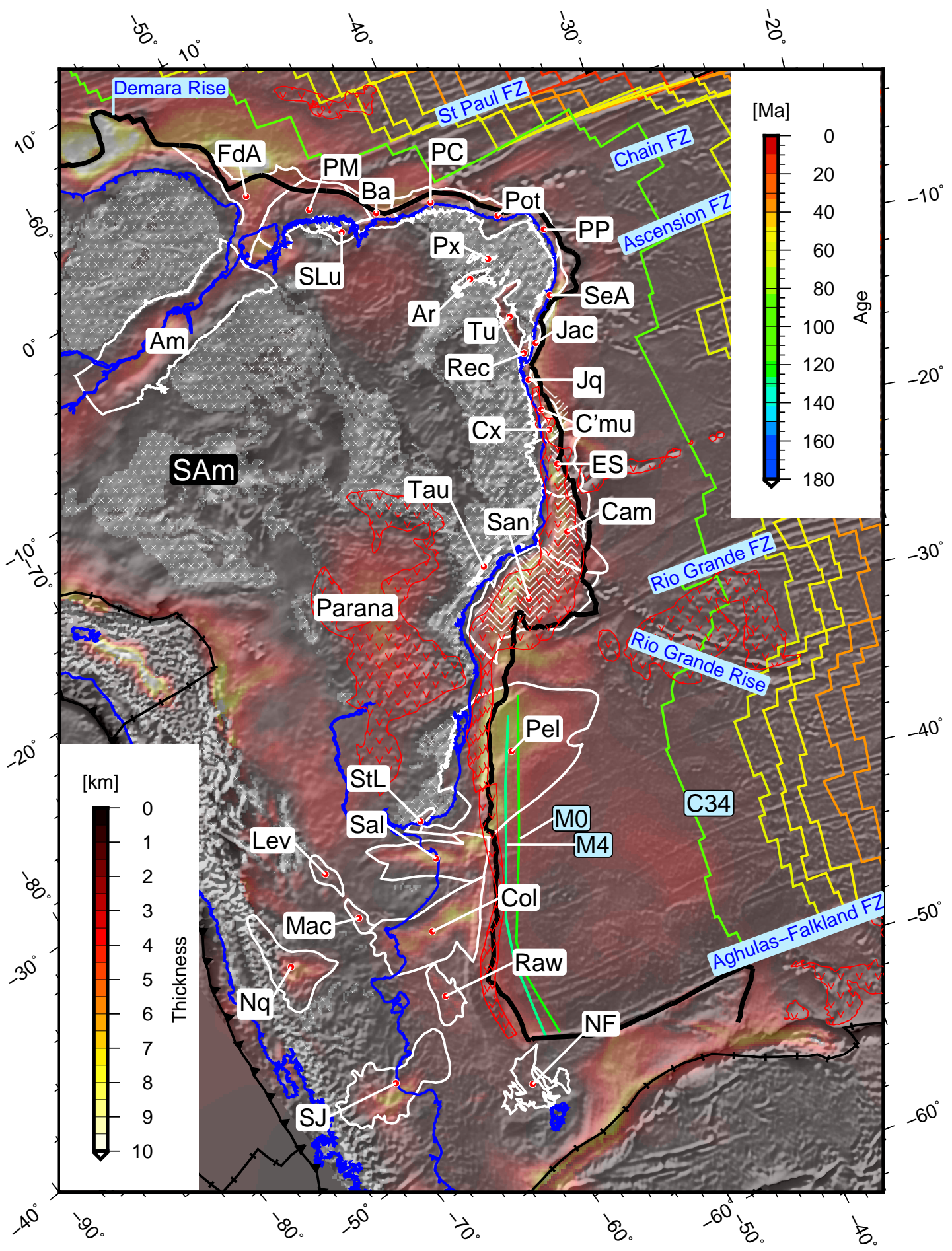

Fig. 8. Oblique Mercator map of present-day South America (SAm), with onshore topography (ETOPO1; Amante and Eakins, 2009), offshore free-air gravity (Sandwell and Smith, 2009), both greyscale, and gridded sediment thickness (Exxon Production Research Company, 1985) superimposed. Map legend as in Fig. 5. White polygons denote sedimentary basins (N to S): FdA - Foz do Amazon; PM - ParaMaranhao; Ba - Barreirinhas; PC - Piaui-Ceara; SLu - São Luis Graben; Px - Rio do Peixe; Pot - Potiguar; PP - Pernambuco-Paraiba; Ar Araripe; SeA - Sergipe-Alagoas; Tu - Tucano; Re - Recôncavo; Jac - Jacuipe; Am - Amazonas; C'mu - Camamu; Cx - Cumuruxatiba; ES - Espirito Santo; Cam - Campos; San - Santos; Tau - Taubaté; Parana - Parana Basin; Pel - Pelotas; StL - Santa Lucia; Sal - Salado; Lev General Levalle; Col - Colorado; Mac - Maccachin; Nq - Neuqén; Raw - Rawson; NF - North Falklands; SJ - San Jorge. Coloured lines are oceanic crust ages from Müller et al. (2008). Plate boundaries (thin black decorated lines) after Bird (2003). Origin of map projection at $50^{\circ} \mathrm{S}, 20^{\circ} \mathrm{W}$; azimuth of oblique equator $-65^{\circ}$. 
(Moulin et al., 2012, 2009; Torsvik et al., 2009; Eagles, 2007; Nürnberg and Müller, 1991; Unternehr et al., 1988; Sibuet et al., 1984). This zone, obscured by one of the largest continental flood basalt provinces in the world (Peate, 1997; White and McKenzie, 1989), has been characterised as a RR-R triple junction with $100 \mathrm{~km} \mathrm{~N}-\mathrm{S}$ extension (Sibuet et al., 1984); as Paraná-Coehabamba shear zone ( $150 \mathrm{~km}$ dextral offset; Unternehr et al., 1988); as Parana-Chacos deformation zone $(60-70 \mathrm{~km}$ extension and $20-30 \mathrm{~km}$ of strike-slip; Nürnberg and Müller, 1991); as Paraná-Etendeka fracture zone (transtensional boundary, $175 \mathrm{~km}$ lateral offset Torsvik et al., 2009), or, finally, as a dextral strike-slip zone with $150 \mathrm{~km}$ of strike-slip and $70 \mathrm{~km}$ extension (Moulin et al., 2009). Peate (1997) ruled out the possibility of a R-R-R triple junction due to timing of magma emplacement and orientation of the associated dike swarm. The minimum amount of deformation proposed by previous authors is $20-30 \mathrm{~km}$ strike-slip and 60-70 km extension (Nürnberg and Müller, 1991). In analogy to the well documented CARS and the discussion of the TBL above, such significant displacement should have resulted in a set of prominent basins extending well beyond the cover of the Paraná flood basalt province and manifested itself as a major break along the South American continental margin, similar to the Colorado and Salado basins further south. Although sub-basalt basin structures have been reported (Eyles and Eyles, 1993; Exxon Production Research Company, 1985), there is no evidence of a large-scale continental shear zone obscured by the Paraná large igneous province (LIP).

In our model we have subdivided the present-day South American continent into the following tectonic blocks, partly following previous authors (Fig. 1; e.g. Moulin et al., 2009; Torsvik et al., 2009; Macdonald et al., 2003; Nürnberg and Müller, 1991; Unternehr et al., 1988s ):

1. The main South American Platform (SAm), extending from the Guyana Craton in the north to the Rio de la Plata Craton in the south, with the exception of the NE Brazilian Borborema Province.

2. The NE Brazilian Borborema Province block (BPB).

3. The Salado Sub-plate, located between the Salado and Colorado basins.

4. The Patagonian extensional domain south of the Colorado Basin, composed of the rigid Pampean Terrane, North Patagonian Massif, Rawson block, San Julian block, the Deseado block, and Malvinas/Falkland block, and the Maurice Ewing Bank extended continental crust.

\subsubsection{Northeast Brazil}

The Borborema Province block (BPB; Figs. 1 and 8) is located in NE Brazil and separated from the South American Plate along a N-S-trending zone extending from the Po- tiguar Basin on the eastern Brazilian equatorial Atlantic margin southwards to the Recôncavo-Tucano-Jatobá rift (RTJ, Fig. 8). Here, a set of isolated Early Cretaceous rift basins (e.g. Araripe and Rio do Peixe basins) as well as abundant evidence of reactivated Proterozoic-aged basement structures and shear zones indicate distributed, but highly localised, lithospheric deformation during the opening of the South Atlantic rift (de Oliveira and Mohriak, 2003; Matos, 2000; Mohriak et al., 2000; Chang et al., 1992; Matos, 1992; Milani and Davison, 1988; Castro, 1987). Rifting commenced in the latest Jurassic/Berriasian and lasted until the mid-Barremian, well documented through extensive hydrocarbon exploration (Matos, 2000, 1999; Szatmari and Milani, 1999; Magnavita et al., 1994; Chang et al., 1992; Milani and Davison, 1988).

Similar to the smaller tectonic blocks in the Benue Trough region, we regard the lithospheric deformation affecting this block caused by the motions of the larger surrounding tectonic plates. The Borborema Province is "crushed" during the early translation of South America relative to Africa with extension in the west Congo cratonic lithosphere localised along existing and reactivated basement structures, leading to small, spatially confined basins such as the Araripe, Rio do Peixe, Iguatu and Lima Campos.

We model the rifting in the Recôncavo-Tucano-Jatobá and Potiguar basins by allowing for $\approx 40$ and $30 \mathrm{~km}$ extension, respectively, through relative motions between South America and the Borborema Province block between $143 \mathrm{Ma}$ and $124 \mathrm{Ma}$ (mid-Barremian).

\subsubsection{Southern South America}

The WNW-ESE-striking Punta del Este Basin, the genetically related Salado Basin adjacent to the south and the ENE-WSW-trending Santa Lucia Basin/Canelones Graben system delimit our South American Block towards the south (Fig. 8; Soto et al., 2011; Jacques, 2003; Kirstein et al., 2000; Stoakes et al., 1991; Zambrano and Urien, 1970). Data support the onset of syn-rift subsidence around the latest Jurassic/Early Cretaceous and post-rift commencing at base Aptian (Stoakes et al., 1991). The rift-related structural trend is predominantly parallel to the basin axis, indicating a NNESSW-directed extension. Sediment thicknesses reach $6 \mathrm{~km}$ with crustal thicknesses around $20-23 \mathrm{~km}$ (Croveto et al., 2007) yielding stretching factors of around 1.4. We have implemented $40 \mathrm{~km}$ of NE-SW transtension between $145 \mathrm{Ma}$ and base Aptian for the eastern part of the basin, which is assumed to have been linked towards the west by a zone of diffuse deformation with the General Levalle Basin. We have split the southern Rio de la Plata Craton along the syntaxis of the Salado/Punta del Este Basin between the South American Block and the Salado Sub-plate.

The rigid Salado Block contains the Precambrian core of the Tandilia region and the Palaeozoic Ventania fold belt (Pángaro and Ramos, 2012; Ramos, 2008) and is delimited by the Late Jurassic/Early Cretaceous-aged Colorado, 
Macachín, Laboulaye/General Levalle and San Luis basins in the south, southwest and west, respectively (Fig. 8; Pángaro and Ramos, 2012; Franke et al., 2006; Webster et al., 2004; Urien et al., 1995; Zambrano and Urien, 1970). Basement trends deduced from seismic and potential field data indicate, similar to the Salado Basin, E-W-trending rift structures orthogonal to the SARS and point to N-Sdirected extension/transtension (Pángaro and Ramos, 2012; Franke et al., 2006, J. Autin personal communication, 2012). Pángaro and Ramos (2012) estimate around $45 \mathrm{~km} \mathrm{(20 \% )}$ $\mathrm{N}-\mathrm{S}$-directed extension for the Colorado Basin. Our model assumes $\approx 50 \mathrm{~km}$ of NE-SW-directed transtension for the basin from $150 \mathrm{Ma}$ to base Aptian when relative motions between Patagonian plates and South America cease (Somoza and Zaffarana, 2008).

The Colorado Basin marks the transition between the blocks related to the South American Platform and the Patagonian part of South America (Pángaro and Ramos, 2012), which we here summarise as Patagonian extensional domain. The Patagonian lithosphere south of the Colorado Basin is composed of a series of amalgamated magmatic arcs and terranes with interspersed Mesozoic sedimentary basins (Ramos, 2008; Macdonald et al., 2003; Ramos, 1988; Forsythe, 1982). For the purpose of this paper, the North Patagonian Massif, Rawson Block, Deseado Block and Malvinas/Falkland Island Block are not separately discussed as deformation in the Colorado and Salado basins largely accounts for clockwise rotation of Patagonian South America during the Late Jurassic to Aptian.

\subsubsection{The Gastre shear zone}

The Gastre shear zone has been used in previous plate tectonic models as a major intracontinental shear zone, separating Patagonian blocks from the main South American Plate (Torsvik et al., 2009; Macdonald et al., 2003). However, no substantial transtensional or transpressional features along this proposed fault zone are recognised in this part of Patagonia, nor does the geodynamic framework of southern South America favour the proposed kinematics. A detailed geological study of the Gastre fault zone area lead von Gosen and Loske (2004) to conclude that there is no evidence of a Late Jurassic-Early Cretaceous shear zone in the Gastre area. Our model does not utilise a Gastre Shear Zone to accommodate motions between the South American and Patagonian blocks.

\section{Plate reconstructions}

The plate kinematic evolution of the South Atlantic rift and associated intracontinental rifts preserved in the African and South American plates, is presented as self-consistent kinematic model with a set of finite rotation poles (Table 2). In the subsequent description of key timeslices we refer to southern Africa (SAf) fixed in present-day position. We will focus on the evolution of the conjugate South Atlantic margins. For palaeo-tectonic maps in $1 \mathrm{Myr}$ time intervals please refer to the Supplement.

\subsection{Kinematic scenarios}

Plate motions are expressed in the form of plate circuits or rotation trees in which relative rotations compound in a timedependent, non-commutative way. The core of our plate tectonic model is the quantified intraplate deformation which allows us to indirectly model the time-dependent velocities and extension direction in the evolving South Atlantic rift. Between initiation and onset of seafloor spreading, the plate circuit for the South American Plate is expressed by relative motions between the African sub-plates (Fig. 9). The kinematics of rifting are well constrained through structural elements and sedimentation patterns, however, the timing of extension carries significant uncertainties due to predominately continental and lacustrine sediment infill. Limited direct information from drilling into the deepest parts of these rifts is publicly available. The regional evolution allows for a relatively robust dating of the onset of deformation at the base Cretaceous in all major rift basins (e.g. Janssen et al., 1995), whereas the onset of post-rift subsidence in the CARS and WARS, is not as well constrained and further complicated through which have experienced subsequent phases of significant reactivation (e.g. Guiraud et al., 2005).

The design of our plate circuit (Fig. 9) implies that the timing of rift and post-rift phases significantly affect the resulting relative plate motions between South America and southern Africa. We have tested five alternative kinematic scenarios by varying the duration of the syn-rift phase in the African intracontinental rifts, and along the equatorial Atlantic margins to evaluate the temporal sensitivity of our plate model (Table 3). The onset of syn-rift was changed between $140 \mathrm{Ma}$ and $135 \mathrm{Ma}$ in the CARS and WARS, along with the end of the syn-rift phase ranging between $110 \mathrm{Ma}$ and $100 \mathrm{Ma}$. For the equatorial Atlantic rift, we evaluated syn-rift phase onset times between $140 \mathrm{Ma}$ and $132 \mathrm{Ma}$ (top Valanginian). Additionally, we included the plate model of Nürnberg and Müller (1991) with forced break-up at $112 \mathrm{Ma}$ ("NT91"; Torsvik et al., 2009) in our comparison. Flowlines for each alternative scenario were plotted and evaluated against observed lineations and fracture zone patterns of filtered free-air gravity. The implied extension history for the conjugate South Atlantic passive margins was used as a primary criterion to eliminate possible alternative scenarios. In the preferred model PM1, rifting along SARS, CARS, WARS, and EqRS starts simultaneously around the early Berriasian (here: $140 \mathrm{Ma}$ ). It satisfies geological (timing and sequence of events) and geophysical observations (alignment of flowlines with lineaments identified in the gravity data) for all marginal basins. Alternatively tested models introduced kinematics such as transpression in certain parts of the margins for which are not supported by the geological record. All 
Table 2. Finite rotation parameters for main rigid plates for preferred South Atlantic rift model M1. Abbreviations are Abs - absolute reference frame; SAf - southern Africa; NEA - northeast Africa; NWA - northwest Africa; Sal - Salado Sub-plate; NPM - North Patagonian Massif block; CM - Mesozoic magnetic anomaly chron; y - young; o - old. Magnetic anomaly timescale after Gee and Kent (2007). For microplate rotation parameters please see electronic Supplement.

\begin{tabular}{lllllll}
\hline $\begin{array}{l}\text { Moving } \\
\text { plate }\end{array}$ & Age & Lon & Lat & Angle & Fixed & plate \\
\hline SAf & 100.00 & 14.40 & -29.63 & -20.08 & Abs & O’Neill et al. (2005) \\
SAf & 110.00 & 6.61 & -29.50 & -26.77 & Abs & Steinberger and Torsvik (2008) \\
SAf & 120.00 & 6.11 & -25.08 & -30.45 & Abs & Steinberger and Torsvik (2008) \\
SAf & 130.00 & 5.89 & -25.36 & -33.75 & Abs & Steinberger and Torsvik (2008) \\
SAf & 140.00 & 7.58 & -25.91 & -38.53 & Abs & Steinberger and Torsvik (2008) \\
SAf & 150.00 & 10.31 & -27.71 & -37.25 & Abs & Steinberger and Torsvik (2008) \\
\hline NEA & 110.0 & 0.0 & 0.0 & 0.0 & SAf & \\
NEA & 140.0 & -0.13 & 39.91 & 1.35 & SAf & Fit \\
\hline NWA & 110.0 & 0.0 & 0.0 & 0.0 & NEA & \\
NWA & 140.0 & 25.21 & 5.47 & 2.87 & NEA & Fit \\
\hline SAm & 83.5 & 61.88 & -34.26 & 33.51 & SAf & Nürnberg and Müller (1991), CAn34 \\
SAm & 96.0 & 57.46 & -34.02 & 39.79 & SAf & Linear interpolation \\
SAm & 120.6 & 51.28 & -33.67 & 52.35 & SAf & Anomaly CM0ry \\
SAm & 120.6 & 52.26 & -34.83 & 51.48 & NWA & Crossover CMOry \\
SAm & 126.57 & 50.91 & -34.59 & 52.92 & NWA & Anomaly CM4no \\
SAm & 127.23 & 50.78 & -34.54 & 53.04 & NWA & Anomaly CM7ny \\
SAm & 140.0 & 50.44 & -34.38 & 53.40 & NWA & Fit \\
\hline NPM & 124.05 & 0.0 & 0.0 & 0.0 & Sal & \\
NPM & 150.00 & -35.94 & -63.06 & 4.10 & Sal & Fit - Extension based on Pángaro and Ramos (2012) \\
\hline Sal & 124.05 & 0.0 & 0.0 & 0.0 & SAm & \\
Sal & 145.00 & -33.02 & -60.52 & 4.40 & SAm & Fit \\
\hline
\end{tabular}

tested scenarios (PM1-PM5), however, show a good general agreement, confirming the robustness of our methodology of constructing indirect plate motion paths for the evolution of the SARS through accounting for intraplate deformation.

The largest difference between our model preferred model PM1 and model NT91 are the start of rifting and the implied kinematic history for the initial phase of extension. Relative motions between SAm and the African plates commences at $131 \mathrm{Ma}$ in NT91. This results in higher extensional velocites and strain rates in NT91 for all extensional domains due to a shorter duration ( $\Delta t=12 \mathrm{Myrs})$ between the onset of plate motions and key tie point at chron M0 (the same across all models).

In the northern Gabon region, the flowlines for model NT91 indicate a rapid initial NNE-SSW translation of South America relative to Africa by about $100 \mathrm{~km}$ for the time from 131-126 Ma (Fig. 10). The resulting transpression along the northern Gabon/Rio Muni margin during this time interval, is not evidenced from the geological record (e.g. Brownfield and Charpentier, 2006; Turner et al., 2003). This initial extension phase is followed by a sudden E-W kink in plate motions from $126 \mathrm{Ma}$ to $118 \mathrm{Ma}$ before the flowlines turn SWNE, parallel to our model(s) for the time of the CNPS. Our modelled extension history for the Gabon margin implies an initial 40-60 km E-W-directed rifting between South America and Africa until $127 \mathrm{Ma}$, followed by a $40^{\circ}$ rotation of the extension direction and subsequent increase in plate velocities.

Along the Nambian margin, predicted initial extension directions for the relative motions between South AmericaAfrica and Patagonian terranes-Africa diverge in the central Orange Basin, conjugate to the Colorado and Salado basins (Fig. 11). Northward from here, relative motions for South America-Africa are directed WNW-ESE, while the Patagonian terranes-Africa motions south of the central Orange Basin imply opening of the southernmost SARS in ENEWSW direction. This is a result of the relative clockwise rotation of the Patagonian terranes away from South America due to the rifting in the Salado/Punta del Este and Colorado basins and accordance with structural observations from the southern Orange Basin (H. Koopmann, personal communication, 2012). These model predictions are supported by the trend of the main gravity lineaments in contrast to the plate motions paths of model NT91 which are not reconcilable with gravity signatures (Fig. 11). 


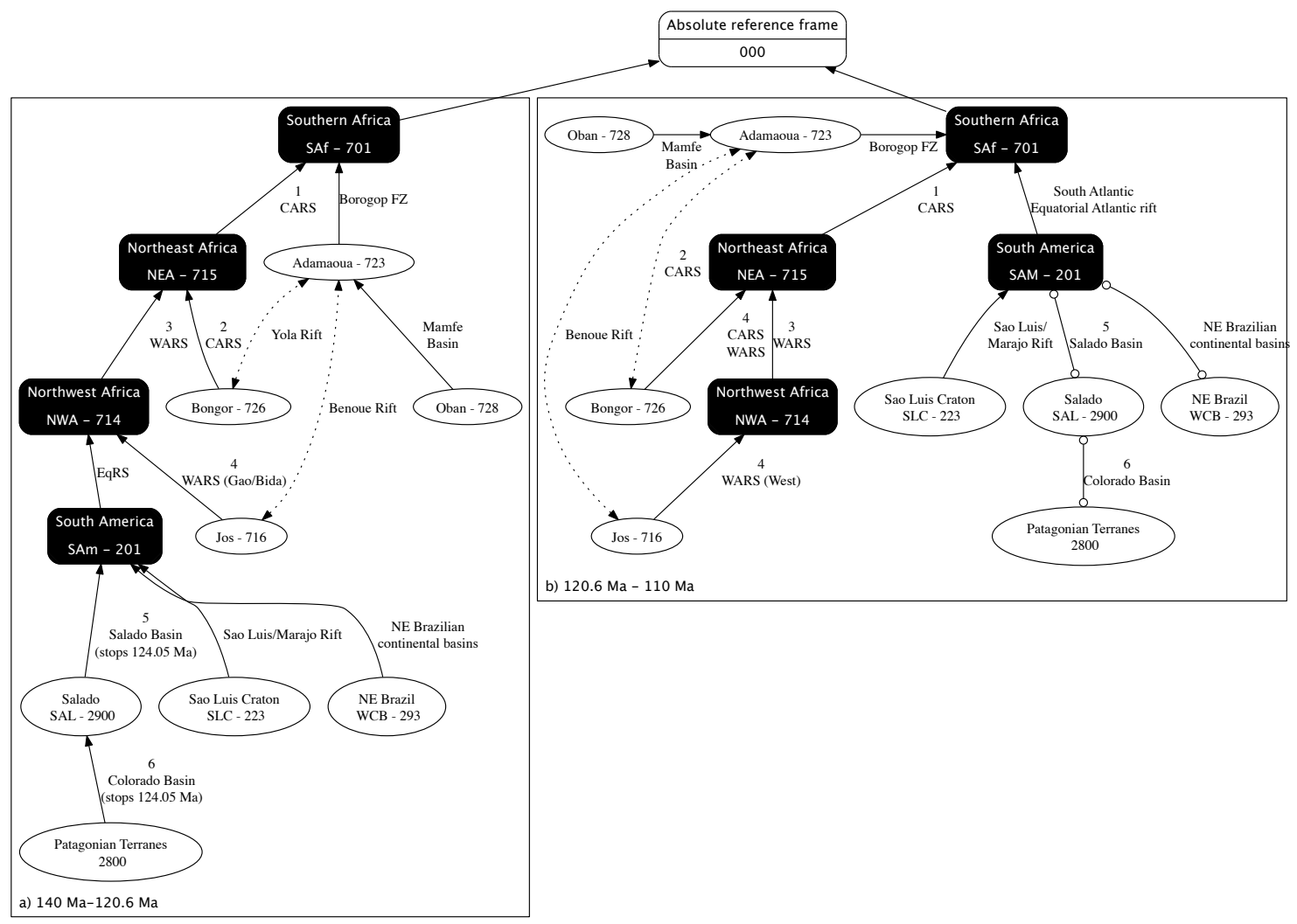

Fig. 9. Visual representation of rotation parameters (Tab.2) as plate circuits used for the plate model for two main stages: (a) 140-120.6 Ma and (b) 120.6-110 Ma for the main lithospheric plates. Integers indicate the Plate-ID number. Integers on connection lines refer to deforming zones (Table 1). Dashed lines indicate areas where extension is indirectly constrained by plate circuit; connections with dots indicate no relative motion. Plate abbreviations.

Table 3. Alternative kinematic scenarios tested for onset and cessation of syn-rift phases in main rift zones.

\begin{tabular}{lll}
\hline Model & Syn-rift onset & Syn-rift cessation in WARS and CARS \\
\hline PM1 & $\begin{array}{l}\text { SARS, CARS, WARS, and EqRS simultaneously: around base } \\
\text { Cretaceous (140 Ma). }\end{array}$ & 110 Ma (early Albian) \\
PM2 & $\begin{array}{l}\text { SARS, CARS, WARS, and EqRS simultaneously: around base } \\
\text { Cretaceous (140 Ma). }\end{array}$ & 100 Ma (late Albian) \\
PM3 & $\begin{array}{l}\text { SARS, CARS and WARS simultaneously: around base Creta- } \\
\text { ceous (140 Ma); EqRS: top Valangian (132 Ma) }\end{array}$ & 110 Ma (early Albian) \\
PM4 & $\begin{array}{l}\text { SARS, EqRS, and CARS simultaneously: around base Creta- } \\
\text { ceous (140 Ma); WARS: base Valangian (135 Ma) }\end{array}$ & 110 Ma (early Albian) \\
PM5 & $\begin{array}{l}\text { SARS and EqRS simultaneously: around base Cretaceous } \\
\text { (140 Ma); WARS and CARS: } 135 \text { Ma }\end{array}$ & 110 Ma (early Albian) \\
NT91 & Model parameters of Nürnberg and Müller (1991) with forced break-up at 112 Ma after Torsvik et al. (2009) \\
\hline
\end{tabular}

In the Santos Basin our preferred model PM1 predicts an initial NW-SE-directed extension in the proximal part, oriented orthogonally to the main gravity gradients, Moho topography and proximal structural elements (Fig. 12; e.g. Stanton et al., 2010; Chang, 2004; Meisling et al., 2001). In the western Santos Basin we model the initial extension phase to be focussed between the São Paulo High/Africa and South America, until the onset of the third extensional phase around the Barremian/Aptian boundary, a time when the inferred oceanic Abimael spreading becomes extinct (Figs. 9 and 12; Scotchman et al., 2010) and the São Paulo High is translated from the African to the South American Plate. 

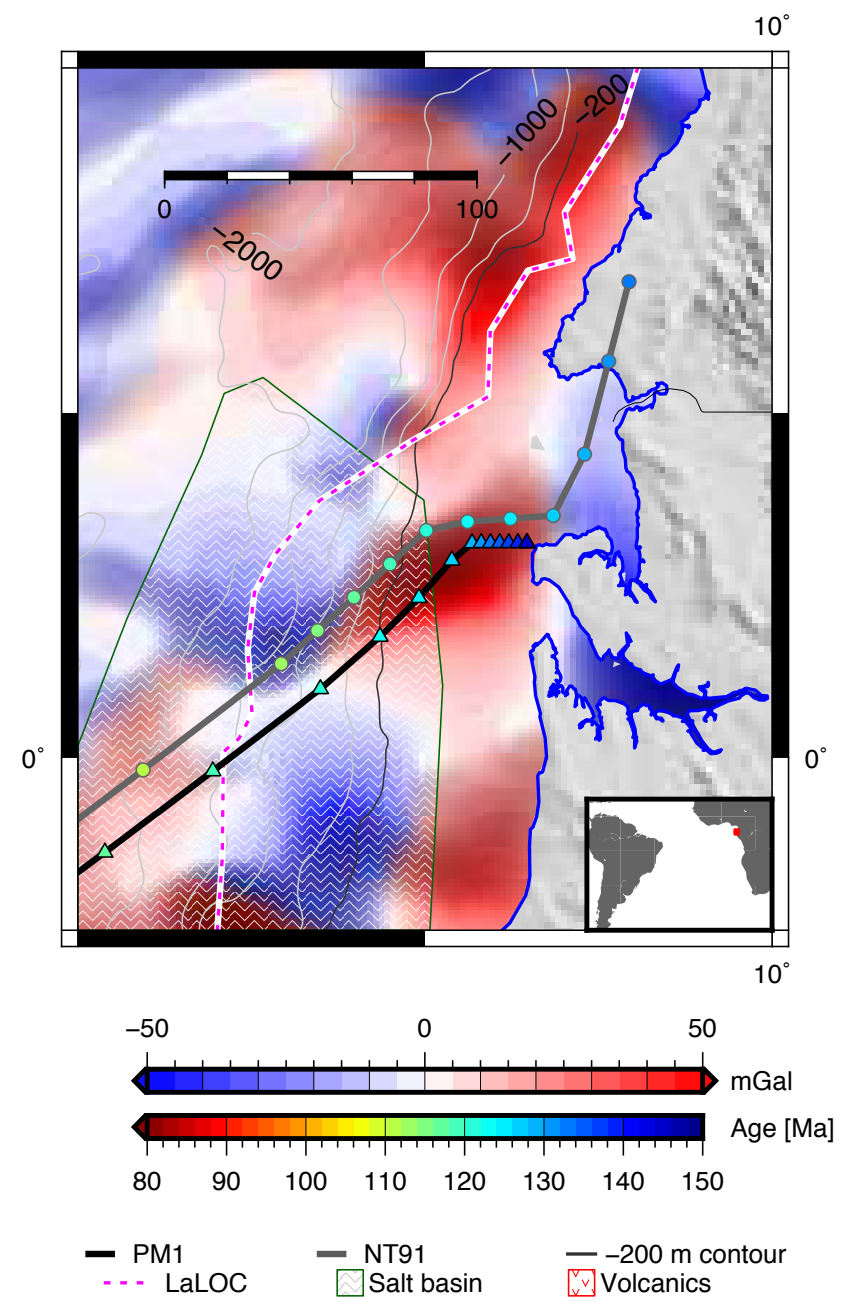

Fig. 10. Age-coded flowlines plotted on filtered free-air gravity basemap (offshore) for the north Gabon/Rio Muni segment of the African margin. Initial-phase flowline direction of our preferred model (PM1, thin black line with circles) is perpendicular to the trend of the present-day coastline, striking NW-SE, and only turns parallel to oceanic transform zones (trending SW-NE) after $\approx 126$ ma. Note that models PM4 \& PM 5 induce a significant amount of compression for the initial phase of relative plate motions and do not agree with geological observations from the area. Relative motions between SAf and SAm in model NT91 commence at $131 \mathrm{ma}$. Circles are plotted in $2 \mathrm{Myr}$ time intervals starting at $144 \mathrm{Ma}$ and from $132 \mathrm{Ma}$ for NT91 (Nürnberg and Müller, 1991; Torsvik et al., 2009). Legend abbreviations: LaLOC - Landward limit of oceanic crust; C. - Contour. Free-air gravity anomalies (Sandwell and Smith, 2009) filtered with 5th-order Butterworth low-pass filter with $35 \mathrm{~km}$ wavelength.

\subsection{Fit reconstruction and the influence of Antarctic plate motions}

The fit reconstruction (Fig. 13) is generated by restoring the pre-rift stage along the intraplate WARS and CARS for the African sub-plates, and in the Recôncavo-Tucano-Jatobá,

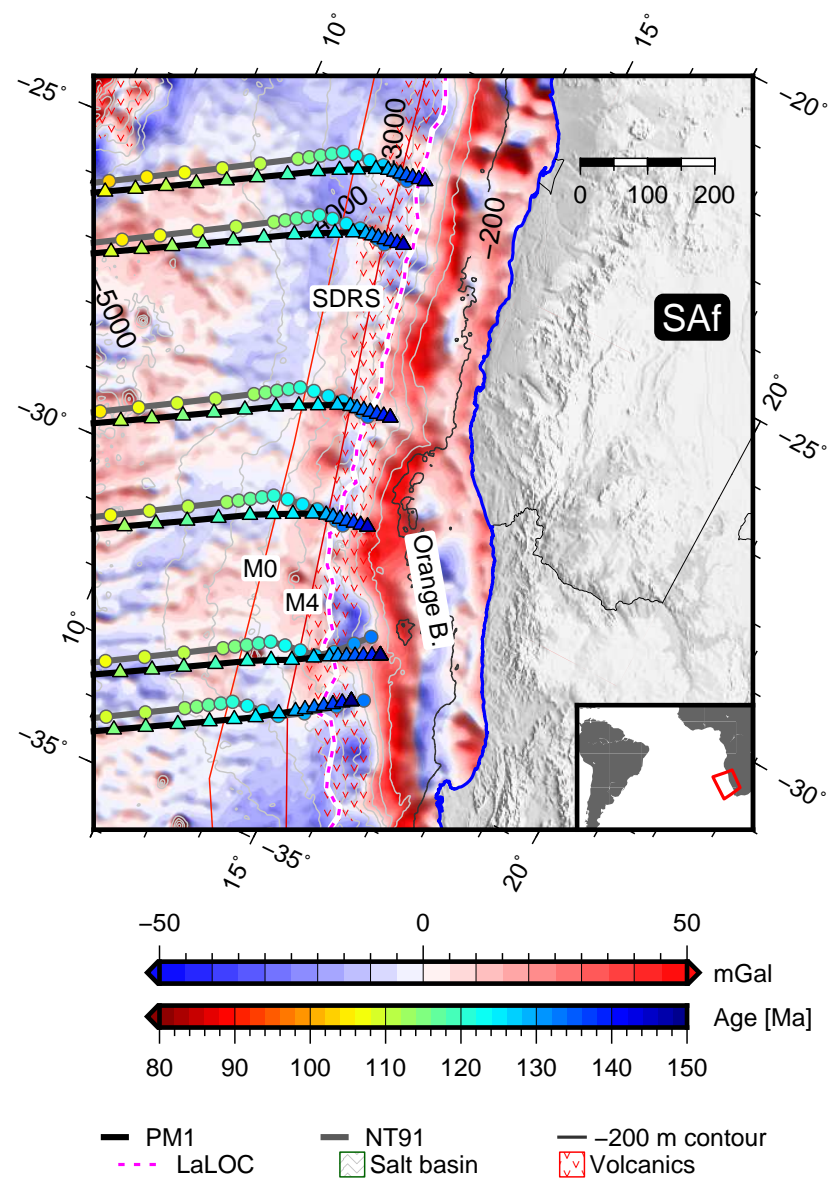

Fig. 11. Age-coded flowlines plotted on filtered free-air gravity basemap (offshore) for the Orange Basin segment along the west African margin. Early phase opening is oblique to present-day margin, with oblique initial extension of SAm relative to SAf (4 northern flowlines) in WNW-ESE direction and initial extension between Patagonian South American blocks and SAf in SW-NE direction (southern 2 flowlines). Note that the Orange Basin is located between the two divergent flowline populations and that a positive gravity anomaly is contemporaneous with the inflection point at 126.57 Ma (M4) and associated velocity increase and extension direction change (cf. Fig. 15) along the margin. Legend/symbology and filter as in Fig. 10.

Colorado and Salado basins for the South American subplates using estimates of continental extension (see Sect. 3). We then use area-balanced crustal-scale cross sections along the South Atlantic continental margins (Sect. 2.3, Fig. 4) in combination with the restored margin geometry published by Chang et al. (1992) to construct pre-rift continental outlines. Margins along the equatorial Atlantic are generally narrow (Azevedo, 1991) and associated with complex transform fault tectonics and few available published crustal-scale seismic data; the location of the LaLOC here is only based on potential field data, with the exception of the Demerara Rise-French Guiana-Foz do Amazon segment where we 


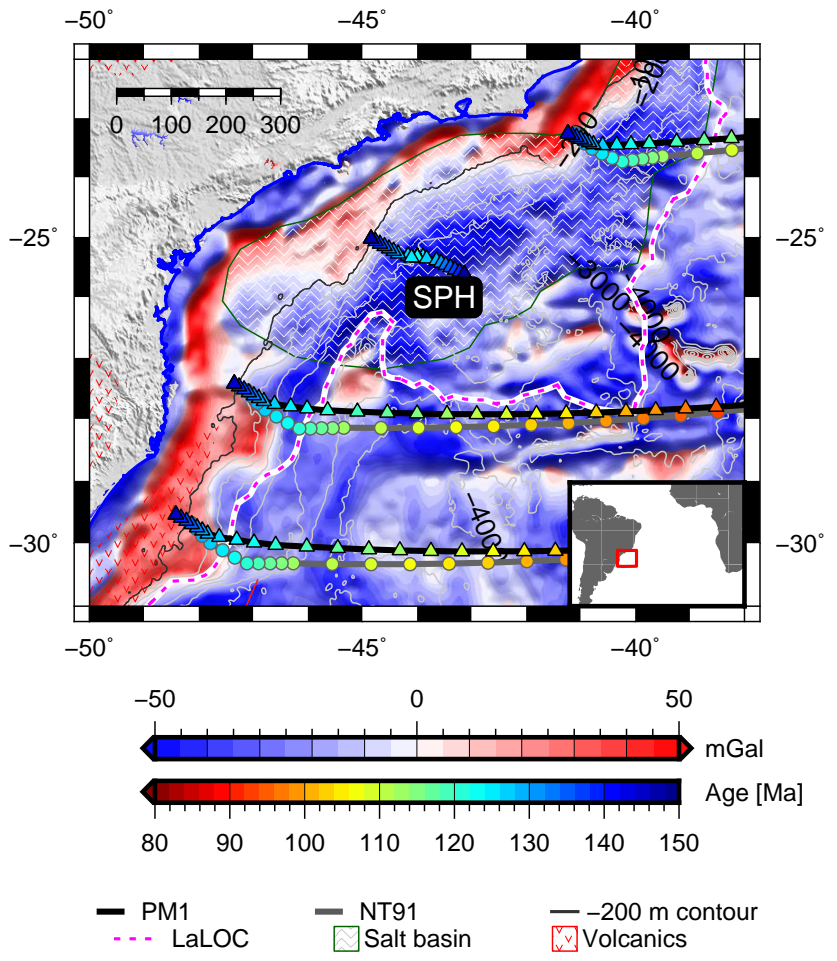

Fig. 12. Age-coded flowlines plotted on filtered free-air gravity basemap (offshore) for the Santos Basin segment on South American margin. SPH: São Paulo High in the outer Santos Basin. Note that initial NW-SE relative extensional direction as predicted by the plate model is perpendicular to the Santos margin hingeline (cf. Meisling et al., 2001, for details on the crustal structure in along the inner Santos Basin margin) and does conform to observed structural patterns in the extended continental crust of the SPH (cf. Chang, 2004). Legend/symbology and filter as in Fig. 10

have utilised Greenroyd et al. (2008, 2007). We allow on average $100 \mathrm{~km}$ of overlap between the present-day continental margins in the EqRS (Fig. 14), compared to a few hundred $\mathrm{km}$ in the central part of the SARS. Total stretching estimates for profiles across the margins for the central and southern South Atlantic segment range between 2.3 and 3.8 for the 10 profiles shown in Fig. 4. South America is subsequently visually fitted against the west African and African equatorial Atlantic margins using key tectonic lineaments such as fracture zone end points and margin offsets (Fig. 13). Transpressional deformation has affected the conjugate Demerara Rise/Guinea Plateau submerged promontories, resulting in shortening of both conjugate continental margins during the opening of the SARS (Basile et al., 2013, 2005; Benkhelil et al., 1995). Our reconstructions hence show a gap of $\approx 50 \mathrm{~km}$ between the Demerara Rise and the Guinea Plateau at the western EqRS as we have not restored this shortening (Fig. 13).

The dispersal of Gondwana into a western and eastern part was initiated with continental rifting and break-up along the incipient Somali-Mozambique-Wedell Sea rift (e.g. König and Jokat, 2006; Norton and Sclater, 1979). NE-SW-directed displacement of Antarctica as part of eastern Gondwana southwards relative to South America and Africa creates an extensional stress field which affects southernmost Africa and the present-day South American continental promontory comprised of the Ewing Bank and Malvinas/Falkland Islands and the proto-Weddell Sea from the mid-Jurassic onwards (König and Jokat, 2006; Macdonald et al., 2003).

Our pre-rift reconstruction for the Patagonian extensional domain takes into account possible earlier phases of extension which have affected, for example, the San Jorge, Deseado or San Julían basins (Jones et al., 2004; Homovc and Constantini, 2001) and hence should represent a snapshot at $140 \mathrm{Ma}$, rather than a complete fit reconstruction which restores all cumulative extension affecting the area in Mesozoic times. Initial rifting of this region preceding relative motions between South America and Africa is recorded by Oxfordian-aged syn-rift sediments in the Outeniqua Basin in southern Africa as well as subsidence and crustal stretching in the North Falkland Basin and the Maurice Ewing Bank region (Fig. 8; Jones et al., 2004; Paton and Underhill, 2004; Macdonald et al., 2003; Bransden et al., 1999). The overall NE-SW extension causes a clockwise rotation of the Patagonian blocks away from SAf and SAm, commencing at $\approx 150 \mathrm{Ma}$ in our model, with a fit reconstruction position of the Falkland Islands just south of Aghulas Arch/Outeniqua Basin. This early motion results in the onset of crustal stretching in the North Falkland (150 Ma), Colorado (150 Ma) and Salado (145 Ma) basins which preceeds relative motions between the main African and South American plates (Fig. 13). The resulting relative motion in the southern part of the SARS is NE-SWdirected transtension (Fig. 11), and E-W extension between the Malvinas/Ewing Bank promontory and Patagonia. Our fit reconstruction for the southernmost South Atlantic places the Malvinas/Falkland Islands immediately south of the Aghulas Arch/Outeniqua Basin. Based on published extension estimates for relevant basins in southern Patagonia/offshore $\mathrm{Ar}$ gentina (e.g. Jones et al., 2004), alternative pre-rift reconstructions placing the Falkland Islands further east and excessive microplate rotation (Mitchell et al., 1986) cannot be reconciled with the currently available data.

\subsection{Phase I: Initial opening - Berriasian to late Hauterivian (140-126.57 Ma)}

Extensional deformation along the WARS, CARS and SARS is documented as starting in the Early Cretaceous (Berriasian) by the formation of intracontinental rift basins and deposition of lacustrine sediments along the conjugate South Atlantic margins (Chaboureau et al., in press; Poropat and Colin, 2012; Dupré et al., 2007; Brownfield and Charpentier, 2006; Bate, 1999; Cainelli and Mohriak, 1999; Coward et al., 1999; Karner et al., 1997; Chang et al., 1992; Guiraud et al., 1992). Here, we use $140 \mathrm{Ma}$ as the absolute 


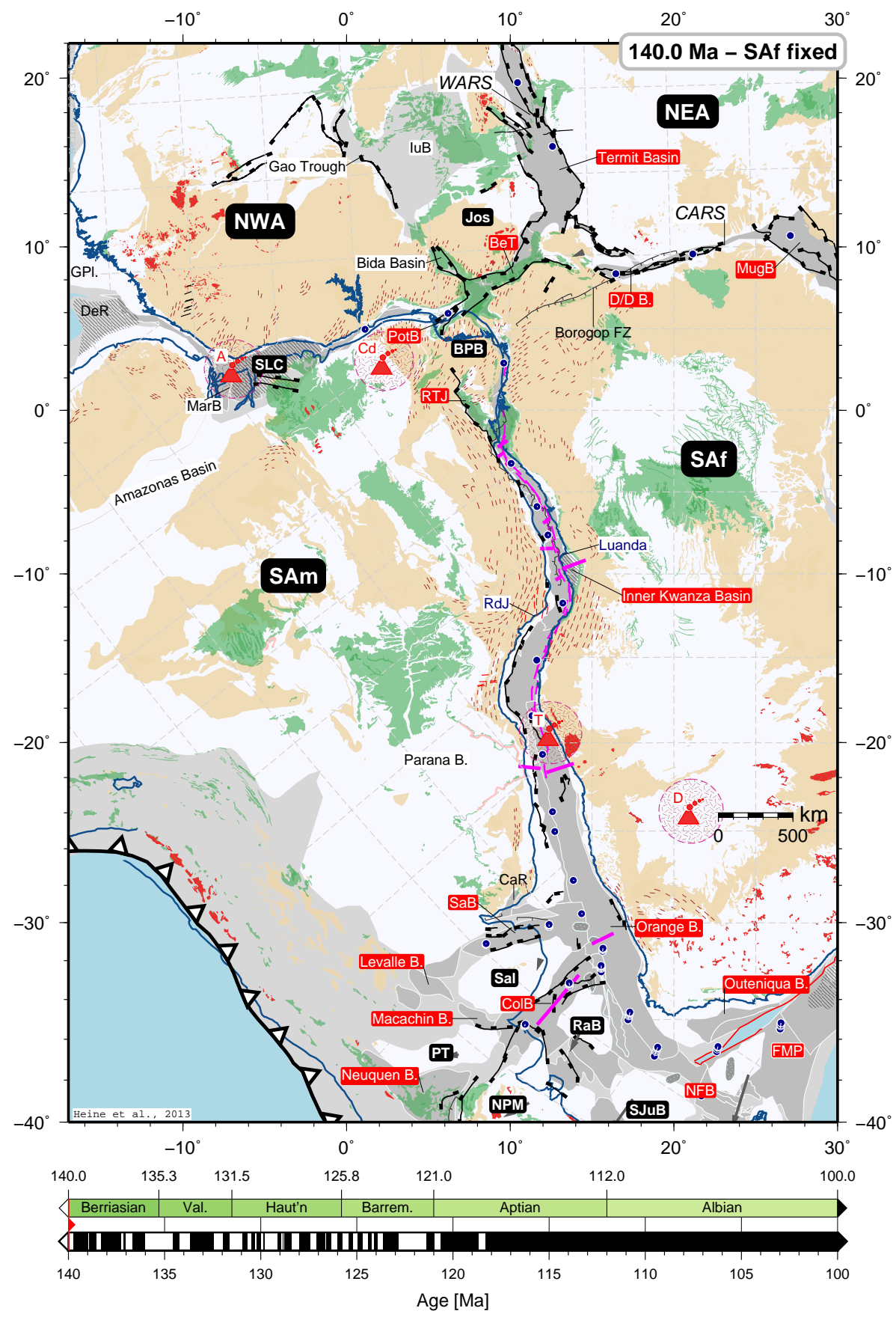

Fig. 13. Plate tectonic reconstruction at $140 \mathrm{Ma}$, Africa fixed in present-day coordinates. For map legend see Fig. 22; bottom colour scales indicate geological stages and magnetic reversals with red diamond indicating time of reconstruction; abbreviations here: $\mathrm{T}-\mathrm{Tithonian}$; Val. - Valaginian; Haut'n - Hauterivian; Barrem. - Barremian. Restored continental margin is indicated by dashed magenta-coloured line, restored profiles (Fig. 4) by solid magenta lines. Rigid lithospheric blocks denoted by black labels: SAf - austral African Plate, BoP - NE Brazilian Borborema Province plate; Jos - Jos Plateau sub-plate; NEA - NE African Plate; NPM - North Patagonian Massif; PT - Pampean Terrane; RaB - Rawson Block; Sal - Salado Sub-plate; SAm - main South American Plate; SJuB - San Julian Block; SLC - São Luis Craton block. Actively extending basins are indicated by red background in label; post-rift basins are indicated by light grey background in label; abbreviations: BeT - Benue Trough; CaR - Canelones rift; D/D B. - Doba and Doseo basins; ColB - Colorado Basin; IuB - Iullemmeden Basin; marB - Marajó Basin; MugB - Muglad Basin; NFB - North Falkland Basin; PotB - Potiguar Basin; TRJ - Reconavo, Jatoba and Tucano basins; SaB - Salado Basin. Other abbreviations: RdJ - Rio de Janeiro; B. - basin; GPl. - Guyana Plateau; DeR - Demerara Rise. Present-day hotspots are shown as volcano symbol and plotted with $400 \mathrm{~km}$ diameter (dashed magenta-coloured circle with hachured fill), assuming that they are stationary over time: A - Ascension; B - Bouvet; Ch - Chad/Tibesti; Ca - Mount Cameroon; Cd - Cardno Seamount; D - Discovery; T - Tristan da Cuñha. 


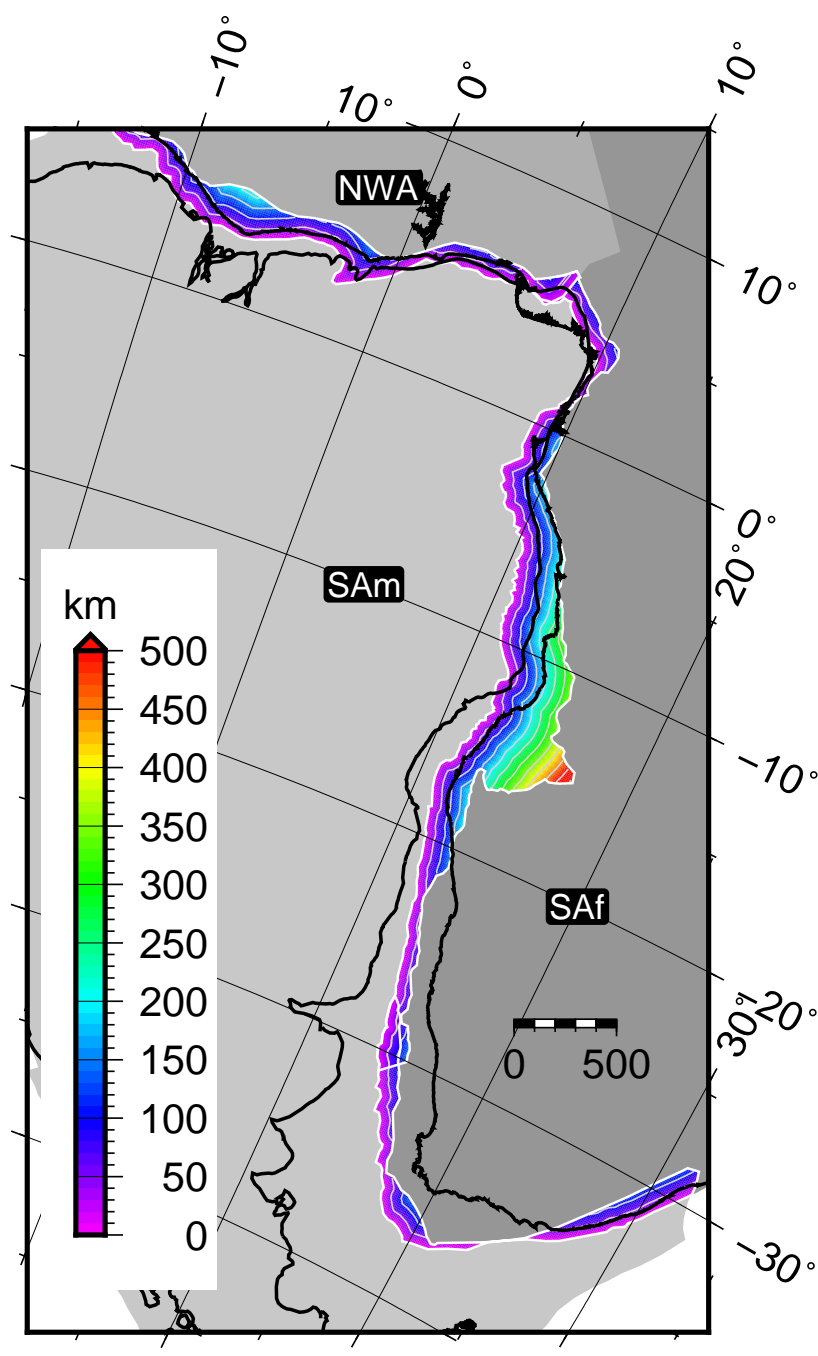

Fig. 14. Overlap between the conjugate present-day landward limits of the oceanic crust (LaLOC) for South America (SAm), southern Africa (SAf) and northwest Africa (NWA). Shown is the fit reconstruction at 143 with SAf fixed in present-day position. Spacing between contour lines is $50 \mathrm{~km}$, present-day coastlines as thick black lines. Note that the position of the LaLOC along the volcanic margins in southern part of the South Atlantic rift is not well constrained. Largest overlap is created between the Campos/Santos Basin margin and the southern Kwanza/Benguela margin, implying up to $500 \mathrm{~km}$ extension for the SE'most Santos Basin.

starting age of the onset of deformation in the South Atlantic, Central and West African Rift Systems (lower Berriasian in our Geek07/GTS04 hybrid timescale, Fig. 2). In the southern part of the SARS, SW-directed extension has already commenced in the latest Jurassic with syn-rift subsidence in the Colorado, Salado, Orange and North Falkland basins (Séranne and Anka, 2005; Jones et al., 2004; Clemson et al., 1999; Maslanyj et al., 1992; Stoakes et al., 1991). Evidence of deformation and rifting along the EqRS during the Early Cretaceous is sparse; however, indications of magmatism

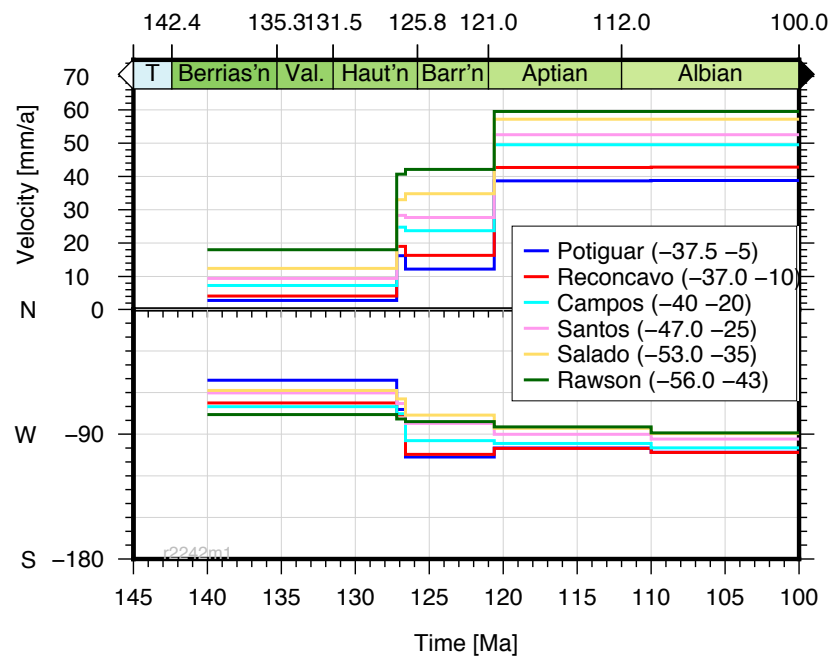

Fig. 15. Relative separation velocities and directions between 6 South American and Patagonian points relative to a fixed southern African plate using preferred plate kinematic model. Upper portion of figure shows extensional velocities over time, lower portion shows extension direction relative to a fixed southern African plate.

and transpressional deformation are found in basins along the margin (e.g. Marajó Basin, São Luis rift; Soares Júnior et al., 2011; Costa et al., 2002; Azevedo, 1991). The FerrerUrbanos-Santos Arch is an E-W-trending basement high between the proximal parts of the Barrerinhas Basin and the onshore Parnaiba Basin which was generated by transpression during the Neocomian (Azevedo, 1991).

Extension in all major rift basins occurs at slow rates during the initial phase, with separation velocities between SAm and SAf around $2 \mathrm{~mm} \mathrm{a}^{-1}$ in the Potiguar/Rio Muni segment and up to ca. $20 \mathrm{~mm} \mathrm{a}^{-1}$ in the southernmost SARS segment, closer to the stage pole equator (Fig. 15). Extensional velocities in the magmatically dominated margin segments of the southern South Atlantic are well above $10 \mathrm{~mm} \mathrm{a}^{-1}$. The predominant extension direction changes from NW-SE in the northern SARS segment to WNW-ESE in the southern part, and SSW-NNE for the conjugate Patagonia-SAf segment (Figs. 15 and 13-16). Along the central SARS segment, this phase corresponds to "Rift Phase 1" of Karner et al. (1997) with broadly distributed rifting.

Flowlines derived from the plate model for the early extension phase correlate well with patterns observed in the freeair gravity field along the proximal parts of the margins, such as in the northern Orange and inner Santos basins (Figs. 11, 12). Along NE-SW-trending margin segments, such as Rio Muni/Sergipe-Alagoas and Santos/Benguela, the extension is orthogonal to the margin, whereas oblique rifting occurs in other segments. In this context we note that the strike of the Taubaté Basin in SE Brazil ("Tau" in Fig. 8) as well as observed onshore and offshore extensional structures and proximal Moho uplift in the Santos Basin (Stanton et al., 2010; 
Fetter, 2009; Meisling et al., 2001; Chang et al., 1992) are oriented orthogonal to our modelled initial opening direction of the South Atlantic rift. The RTJ rift opens as we model the BPB attached to the west African Congo Craton and Adamaoua Sub-plate, with SAm being relatively displaced northwestward. Here, the Pernambuco shear zone acts as a continuation of the Borogop fault zone into NE Brazil (Matos, 1999). Potiguar Basin and Benue Trough make up one depositional axis, while the RTJ and inner/northern Gabon belong to the central South Atlantic segment.

Around $138 \mathrm{Ma}$ (mid-Berriasian), break-up and seafloor spreading start in isolated compartments between the Rawson Block and the continental margin south of the Orange Basin. The Tristan da Cuñha hotspot has been located beneath the Pelotas-Walvis segment of the SARS since $145 \mathrm{Ma}$ (Figs. 13-16, and palaeo-tectonic maps in the electronic Supplement) and likely caused significant alteration of the lithosphere during the early phase rifting, with the eruption of the Paraná-Etendeka continental flood basalt province occurring between 138 and 129 Ma (Peate, 1997; Stewart et al., 1996; Turner et al., 1994). While we have not included a temporary plate boundary in the Paraná Basin in our model, evidence from the Punta Grossa and Paraguay dike swarms (Peate, 1997; Oliveira, 1989) points to a NE-SW-directed extension, similar to the "Colorado Basin-style" lithospheric extension orthogonal to the main SARS (Turner et al., 1994). Emplacement of massive seaward-dipping reflector sequences dominate the early evolution of the southern SARS segment and are well documented by seismic and potential field data (e.g. Blaich et al., 2011; Moulin et al., 2009; Bauer et al., 2000; Gladczenko et al., 1997). While the delineation of the extent of continental crust along volcanic margins remains contentious, we model a near-synchronous transition to seafloor spreading south of the Walvis Ridge/Florianopolis High around $127 \mathrm{Ma}$ (Figs. 16-17 and the Supplement).

Between 136 and $132 \mathrm{Ma}$, the plume centre is located beneath the present-day South American coastline in the northern Pelotas Basin. Our reconstructions indicate that the westernmost position of a Tristan plume (assumed to be fixed) with a diameter of $400 \mathrm{~km}$ is more than $500 \mathrm{~km}$ east of the oldest Paraná flood basalts, at the northern and western extremities of the outcrop (Turner et al., 1994). Oceanic magnetic anomalies off the Pelotas/northern Namibe margins indicate asymmetric spreading with a predominant accretion of oceanic crust along the African side (Moulin et al., 2009; Rabinowitz and LaBrecque, 1979), which in our reconstructions can be explained through plume-ridge interactions of high magma volume fluxes and relatively low spreading rates (Fig. 15; Mittelstaedt et al., 2008). The São Paulo-Río de Janeiro coastal dike swarms, emplaced between 133 and $129 \mathrm{Ma}$, have any extrusive equivalents in the Paraná LIP (Peate, 1997). The dikes are oriented orthogonal to our modelled initial extension direction, both along the Brazilian as well as along the African margin in southern Angola. Along with a predominant NE-SW-striking metamorphic basement grain presenting inherited weaknesses (Almeida et al., 2000), these dikes are probably related to lithospheric extension along the conjugate southern Campos/Santos-Benguela margin segment of the SARS.

In the southern segment, the Falkland-Aghulas fracture zone is established when the Maurice Ewing Block starts moving with the Patagonian Plate around $134 \mathrm{Ma}$. Strain rate estimates from the Orange Basin support the onset of rifting around 150-145 Ma (Jones et al., 2004).

Towards the late Hauterivian (127 Ma), the width of the enigmatic pre-salt sag basin width has been created by slow, relative extension between SAm and SAf, with extension velocities ranging between 7 and $9 \mathrm{~mm} \mathrm{a}^{-1}$ (Campos/Jatobá, Fig. 15).

\subsection{Phase II: Equatorial Atlantic rupture (126.57-120.6 Ma)}

Following the initial rifting phase which is characterised by low strain rates, deformation along the EqRS between NWA and northern SAm intensifies due to strain localisation and lithospheric weakening (Heine and Brune, 2011). Marginal basins of the EqRS record increasing rates of subsidence/transpression (Azevedo, 1991), and in the southern South Atlantic seafloor-spreading anomalies M4 and M0 indicate a 3-fold increase in relative plate velocities between SAm and African Plates (Figs. 17 and 15). Velocity increases of similar magnitude, albeit with a different timing, are reported by Torsvik et al. (2009) and Nürnberg and Müller (1991). Along the EqRs, Azevedo (1991) describes a set of transpressional structures in the Barreirinhas Basin which caused folding of Albian and older strata and reports 50$120 \mathrm{~km}$ of dextral strike-slip along the Sobradinho Fault in the proximal Barrerinhas basin, pointing towards an early dextral displacement. With the changed kinematics, SAm now rotates clockwise around NWA, causing transtensional opening of basins in the eastern part of the EqRS and about $20 \mathrm{~km}$ of transpression along the Demerara Rise and Guinea Plateau at the western end of the EqRS. This is in accordance with observed compressional structures along the southern margin of the Guinea Plateau and the northeastern margin of the Demerara Rise (Basile et al., 2013; Benkhelil et al., 1995).

The increase in extensional velocities jointly occurs with a sudden change in extension direction from NWSE to more E-W (Fig. 15). Depending on the distance from the stage pole for this time interval, the directional change is between $75^{\circ}$ in the northern SARS (Rio MuniGabon/Potiguar-Sergipe-Alagoas segment) and $30^{\circ}$ in the southern Pelotas/Walvis segment. The directional change visible in the flowlines agrees very well with a pronounced outer gravity high along the Namibian margin (Fig. 11) and lineaments in the Santos Basin (Fig. 12). This change in the plate motions had severe effects on the patterns and distribution of extension in the SARS. Karner et al. (1997) 


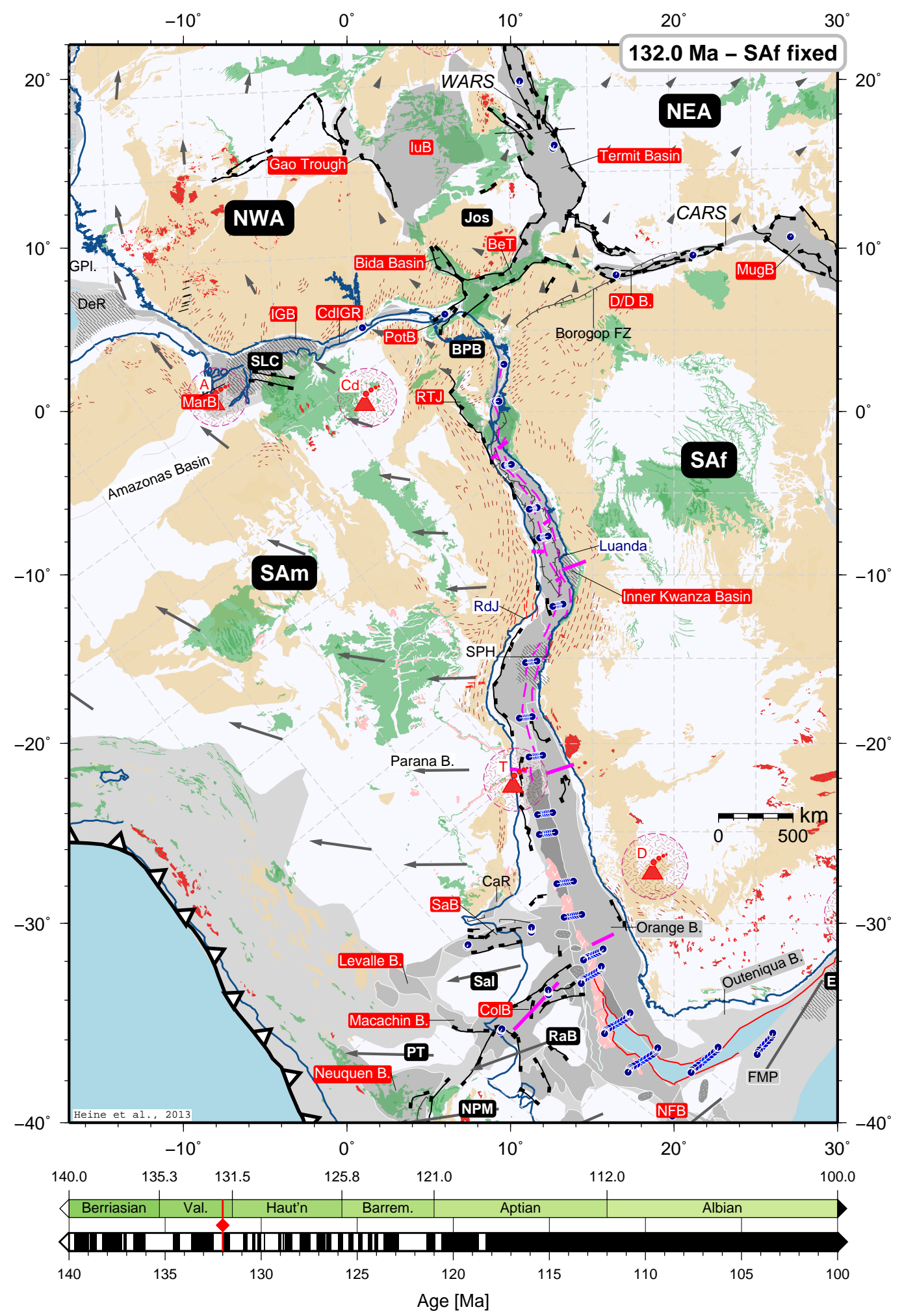

Fig. 16. Plate tectonic reconstruction at $132 \mathrm{Ma}$, with Africa fixed in present-day coordinates. For map legend see Fig. 22, abbreviations as in Fig. 13. Note initial extension directions along the margin rotate from NW-SE in Gabon/Sergipe-Alagoas segment to W-E in Pelotas/Walvis Basin segment with increasing distance from stage pole location. Flowlines between Patagonian blocks in southern South America and southern austral Africa indicate and initial SW-NE directed motions between these plates (cf. Fig 11). In west Africa, the Iullemmeden and Bida basins as well as the Gao Trough are undergoing active extension. Tectonism along the equatorial Atlantic rift increases. Additional abbreviations: DGB - Deep Ghanaian Basin; CdIGR - Côte d'Ivoire/Ghana Ridge and associated marginal basins. 
report a $100 \mathrm{~km}$ westward step of the main axis of lithospheric extension in the Gabon/Cabinda margin segment during their second rift phase (Hauterivian to late Barremian). Along the Rio Muni/north Gabon margin a mild inversion in the pre-break-up sediment is observed (Lawrence et al., 2002), which we relate to the change in plate kinematics, manifested in this margin segment as change from orthogonal/slightly oblique extension to transform/strike-slip. In the Santos Basin, the change in extensional direction results in transtensional motions, most likely responsible for the creation of the Cabo Frio fault zone and localised thinning in proximal parts of the SW Santos basin, now manifested as an "Axis of Basement Low" (Modica and Brush, 2004) north of the São Paulo High. By the time of change in plate motions $(\approx 127 \mathrm{Ma})$, the pre-salt sag basin width had been fully generated (Fig. 17). Increasing extensional velocities resulted in fast, highly asymmetric localisation of lithosphere deformation in the northern and central SARS segments, most likely additionally influenced by the inherited basement grain/structures. This has left large parts of the Phase I rift basin preserved along the Gabon-Kwanza margin, whereas south of the Benguela/Cabo Frio transform the Phase I rift is largely preserved on the Brazilian side.

Davison (2007) reports that from about $124 \mathrm{Ma}$ (early Aptian using Gradstein et al., 2004), extensive evaporite sequences are deposited in areas north of the Walvis Ridge, starting with the Paripuiera salt in the northern Gabon/Jequitinhonha segment and the slightly younger Loeme evaporites in the Kwanza basin. We note that in our reconstructions, the massive volcanic build-ups of the Walvis Ridge/Florianopolis Platform form a large barrier toward the Santos Basin in the north. North of the ridge, extension localised and propagated northwards into the southwestern part of the Santos Basin (the now-aborted Abimael ridge; Scotchman et al., 2010; Mohriak et al., 2010; Gomes et al., 2009) towards the end of this phase.

The São Paulo High remains part of the African lithosphere, which explains the "Cabo Frio counterregional fault trend" in the northern Santos Basin (Modica and Brush, 2004). Prior NW-SE extension, paired with additional thinning and transform motions along the Cabo Frio fault system (Stanton et al., 2010; Meisling et al., 2001), could have formed a shallow gateway through the inner parts of the Santos Basin, allowing the supply of seawater into the isolated central SARS. Dynamic, plume-induced topography (Rudge et al., 2008) from the extensive magmatic activity in the Paraná-Etendeka igneous province might have caused additional lithospheric buoyancy of the extending lithosphere in the Santos Basin.

Seafloor spreading is fully established in a protoSouth Atlantic Ocean basin (Pelotas-Walvis segment to Falkland/Aghulas fracture zone), while oceanic circulation in this segment was probably quite restricted as the Falkland/Malvinas-Maurice Ewing Bank continental promontory had not cleared the southern African margin (Fig. 18).

\subsection{Phase III: Break-up - Aptian to late Albian (120.6-100 Ma)}

Magnetic anomaly chron M0 (120.6 Ma) is clearly identified in large parts of the southern South Atlantic and provides, along with established fracture zones, one major tie point for our reconstruction. Further lithospheric weakening and strain localisation along the EqRS resulted in widespread transtensional motions and related complex basin formation in the marginal basins (Basile et al., 2005; Matos, 2000, 1999; Azevedo, 1991), causing a second increase in extensional velocities between the African and SAm plates and a minor change in separation direction from $120.6 \mathrm{Ma}$ onwards (Fig. 15). We here linearly interpolate the plate velocities during the CNPS (120.6-83.5 Ma) only adjusting plate motion paths along well-established fracture zones.

By $120 \mathrm{Ma}$ (early Aptian, Fig. 18) continental breakup has occurred in the northernmost SARS between the Potiguar/Benin and Pernambuco-Paraiba/Rio Muni margin segments and between the conjugate northern Gabon/Jequitinhonha-Camamu margins with incipient break-up in the remaining part of the central SARS (Espirito Santo/Cabinda-Campos/Kwanza). South of the Cabo Frio/Benguela transform, changes in plate motions resulted in deformation to jump from the Avedis and Abimael ridges in the southwestern Santos Basin (Scotchman et al., 2010; Mohriak et al., 2010; Gomes et al., 2009) towards the African side, rifting the São Paulo High away from the Namibian/Benguela margin. Extensive evaporite deposition continues in most parts of the deforming central SARS, peaking in mid-Aptian times (Karner et al., 2007; Davison, 2007).

By $115 \mathrm{Ma}$ (Middle Aptian, Fig. 19), large parts of the SARS and EqRS have broken up diachronously and entered post-rift thermal subsidence. Our model predicts break-up in the Campos/Kwanza segment by $119 \mathrm{Ma}$, in the westernmost part of the EqRS at $118 \mathrm{Ma}$, in line with deep water basin conditions reported between the Guinea and St. Paul fracture zones (Jones, 1987). In the EqRS our model predicts accretion of oceanic lithosphere in the Deep Ghanaian Basin from $117 \mathrm{Ma}$ onwards, and break-up along the southern Campos/Benguela margin segment in the SARS around $115 \mathrm{Ma}$. For the Gabon margins, Dupré et al. (2007) and Karner et al. (1997) assume the onset of rifting at around $118 \mathrm{Ma}$ and late Barremian-early Aptian, respectively, which is in agreement with our model. Subsidence data from nearly all margin segments in the SARS indicate cessation of fault activity and a change to post-rift thermal subsidence by this time, with the exception of the outer Santos Basin, where the final break-up between SAf and SAm occurs between 113-112 Ma. This timing is in agreement with the deposition of the youngest evaporites in the outer Santos Basin around $113 \mathrm{Ma}$ (Davison, 2007). We hypothesise that the early salt 


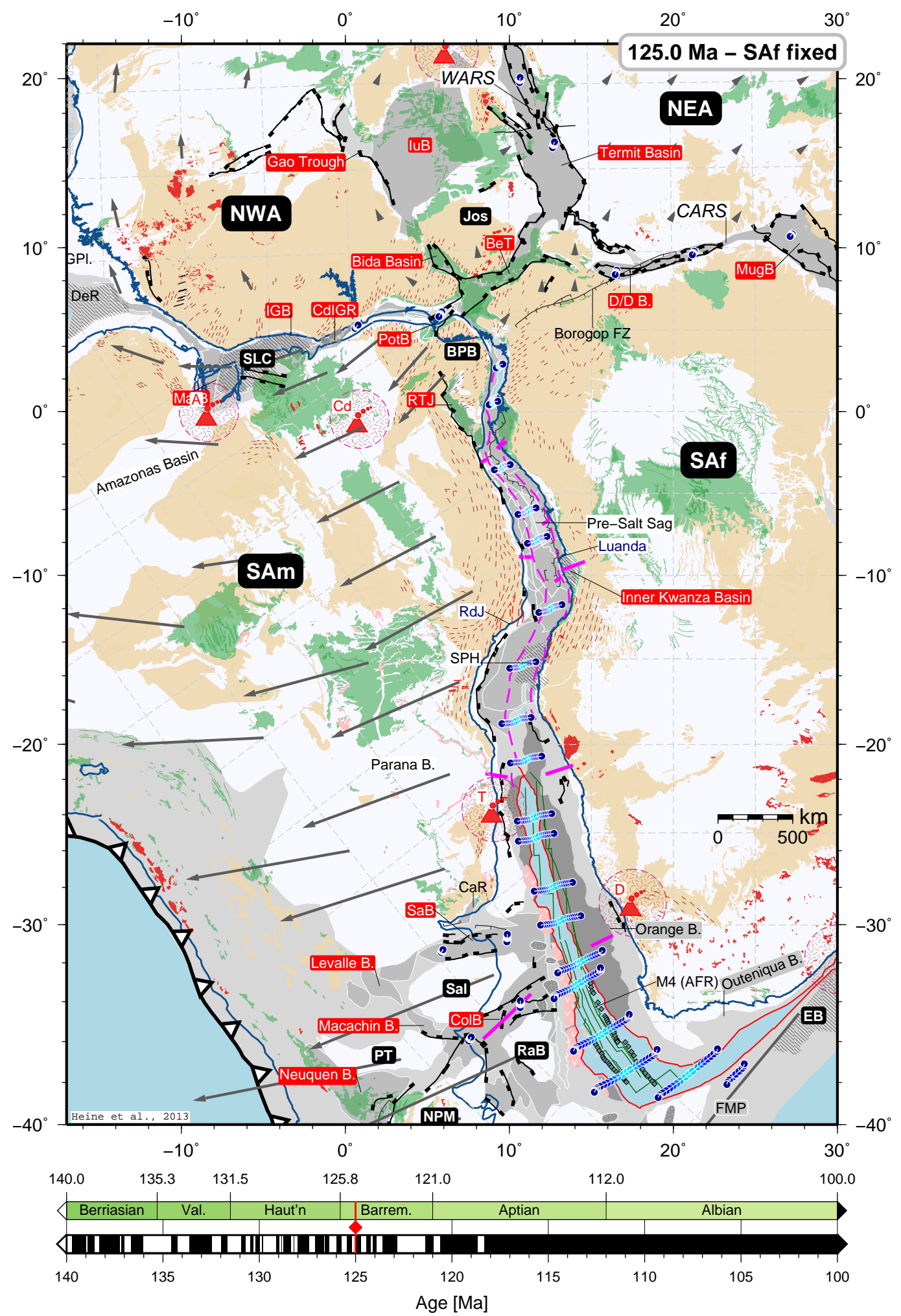

Fig. 17. Plate tectonic reconstruction at $125 \mathrm{Ma}$, with Africa fixed in present-day coordinates. For map legend see Fig. 22, abbreviations as in Fig. 13. Note that at this time, the west African pre-salt basin width is generated and seafloor spreading is abutting against the Walvis Ridge/Florianopolis Ridge at the southern margin of the Santos Basin, with extension and possible rifting along the Abimael Ridge in the inner SW part of the Santos Basin (cf. Scotchman et al., 2010). Relative rotation of SAm to NWA results in $\approx 20 \mathrm{~km}$ of transpression between the Guinea Plateau and the Demerara Rise. Rift basins along the equatorial Atlantic rift are all actively subsiding. Additional abbreviations: SPH - São Paulo High; EB - Maurice Ewing Bank. 


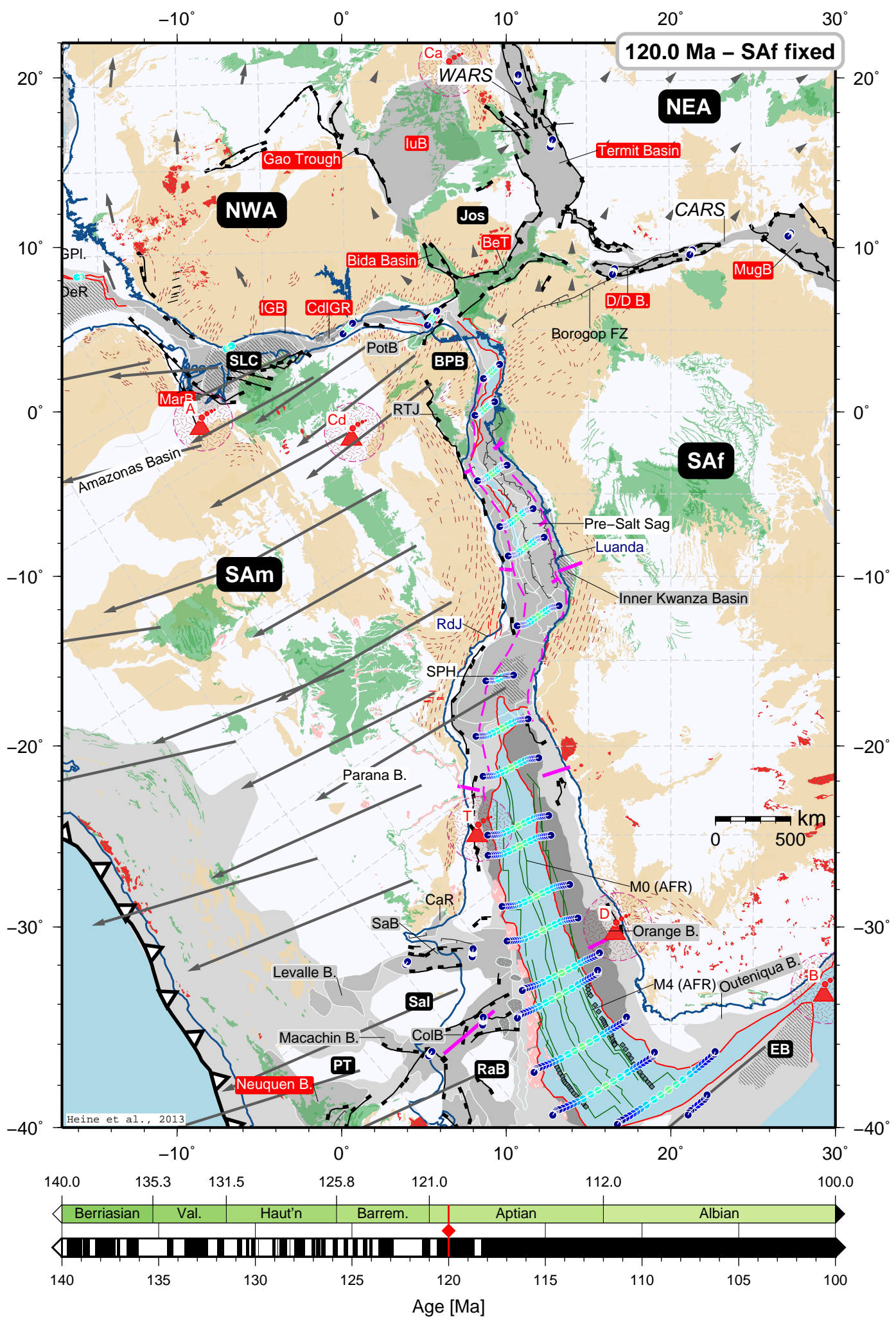

Fig. 18. Plate tectonic reconstruction at $120 \mathrm{Ma}$, with Africa fixed in present-day coordinates. For map legend see Fig. 22, abbreviations as in Fig. 13. Significant increase in extensional velocities causes break-up and subsequent seafloor spreading in the northernmost part of the South Atlantic rift extending down to the conjugate Cabinda/Espirito Santo segment. Due to changed kinematics, rifting and extension in the Santos/Benguela segment focusses on the African side, causing the transfer of the São Paulo High block onto the South American Plate. Break-up also occurs between Guinea Plateau and Demerara Rise in the westernmost part of the equatorial Atlantic. 
movement in the Gabon, Kwanza, Espirito Santo, Campos and Santos basins and the observed chaotic salt in the distal part of these basins is related to the fast localisation of lithospheric deformation, break-up and subsequent rapid subsidence during the early Aptian, introducing topographic gradients favouring gravitational sliding and downslope compression in the earliest post-rift (Fort et al., 2004).

Relative plate motions in the CARS and WARS cease around $110 \mathrm{Ma}$ in the early Albian, with most intracontinental rift basins entering a phase of thermal subsidence before subsequent minor reactivation occurred in post-Early Cretaceous times (Janssen et al., 1995; Genik, 1993; Maurin and Guiraud, 1993; Genik, 1992; Guiraud and Maurin, 1992; McHargue et al., 1992). The cessation of rifting in the WARS and CARS results in the onset of transpression along the Côte d'Ivoire-Ghanaian Ridge in the EqRS as the trailing edges of SAm continue to move westward, while NWA now remains stationary with respect to the other African plates. The NWA transform margins now provide a backstop to the westward-directed motions of SAm, causing compression associated with up to $2 \mathrm{~km}$ of uplift to occur along the Ghanaian transform margin between the middle to late Albian (Antobreh et al., 2009; Basile et al., 2005; Pletsch et al., 2001; Clift et al., 1997). Complete separation between African and South American continental lithospheres is achieved at $104 \mathrm{Ma}$ (Fig. 21), while the oceanic spreading ridge clears the Côte d'Ivoire/Ghana Ridge by 100-99 Ma.

\section{Conclusions}

We present a new plate kinematic model for the evolution of the South Atlantic rift. Our model integrates intraplate deformation from temporary plate boundary zones along the West African and Central African Rift Systems as well as from Late Jurassic/Early Cretaceous rift basins in South America to achieve a tight-fit reconstruction between the major plates. Our plate motion hierarchy describes the motions of South America to southern Africa through relative plate motions between African sub-plates, allowing the time-dependent pre-break-up extension history of the South Atlantic rift system to be modelled. Three main phases with distinct velocity and kinematics result through the extension along the Central African, West African and Equatorial Atlantic Rift Systems, exerting significant control on the dynamics of continental lithospheric extension in the evolving South Atlantic rift from the Early Cretaceous to final separation of Africa and South America in the late Albian (104Ma). An intial phase of slow E-W extension in the South Atlantic rift basin from $140 \mathrm{Ma}$ (base Cretaceous) to $127 \mathrm{Ma}$ (late Hauterivian) causes distributed extension in the W-E direction. The second phase from 126 to $121 \mathrm{Ma}$ (late Hauterivian to base Aptian) is characterised by rapid lithospheric weakening along the equatorial Atlantic rift resulting in increased extensional velocities and a change in extension direction to SW-NE.
The last phase commences at $120 \mathrm{Ma}$ and culminates in diachronous break-up along the South Atlantic rift and formation of the South Atlantic Ocean basin. It is characterised by a further increase in plate velocities with a minor change in extension direction.

We argue that our proposed three-stage kinematic history can account for most basin-forming events in the Early Cretaceous South Atlantic, Equatorial Atlantic, Central African and West African Rift Systems and provide a robust quantitative tectonic framework for the formation of the conjugate South Atlantic margins. In particular, our model addresses the following issues related to the South Atlantic basin formation:

- We achieve a tight-fit reconstruction based on structural restoration of the conjugate South Atlantic margins and intraplate rifts, without the need for complex intracontinental shear zones.

- The orientation of the Colorado and Salado basins, oriented perpendicular to the main South Atlantic rift, are explained through clockwise rotation of the Patagonian sub-plates. This also implies that the southernmost South Atlantic rift opened obliquely in a NE-SW direction.

- A rigid South American plate, spanning the Camamu to Pelotas basin margin segments, requires that rifting started contemporaneously in this segment of the South Atlantic rift (Gabon, Kwanza, Benguela and Camamu, Espirito Santo, Campos and Santos basins), although so far stratigraphic data (e.g. Chaboureau et al., in press) indicate differential onset of the syn-rift phase in the various marginal basins.

- The formation of the enigmatic pre-salt sag basin on top of hyperextended crust along the west African margin is explained through a multi-phase and multi-directional extension history in which the initial sag basin width was created through slow $\left(7-9 \mathrm{~mm} \mathrm{a}^{-1}\right)$ continental lithospheric extension until $126 \mathrm{Ma}$ (Late Hauterivian).

- Normal seafloor spreading in the southern segment of the South Atlantic rift commenced at around $127 \mathrm{Ma}$, after a prolonged phase of volcanism affecting the southern South Atlantic conjugate margins.

- Strain weakening along the equatorial Atlantic rift caused an at least 3-fold increase of plate velocities between South America and Africa between 126 and $121 \mathrm{Ma}$, resulting in rapid localisation of extension along the central South Atlantic rift.

- Linear interpolation of plate motions between $120.6 \mathrm{Ma}$ and 83.5 Ma yield break-up ages for the conjugate Brazilian and west African margins which are corroborated by the onset of post-rift subsidence in those basins. 


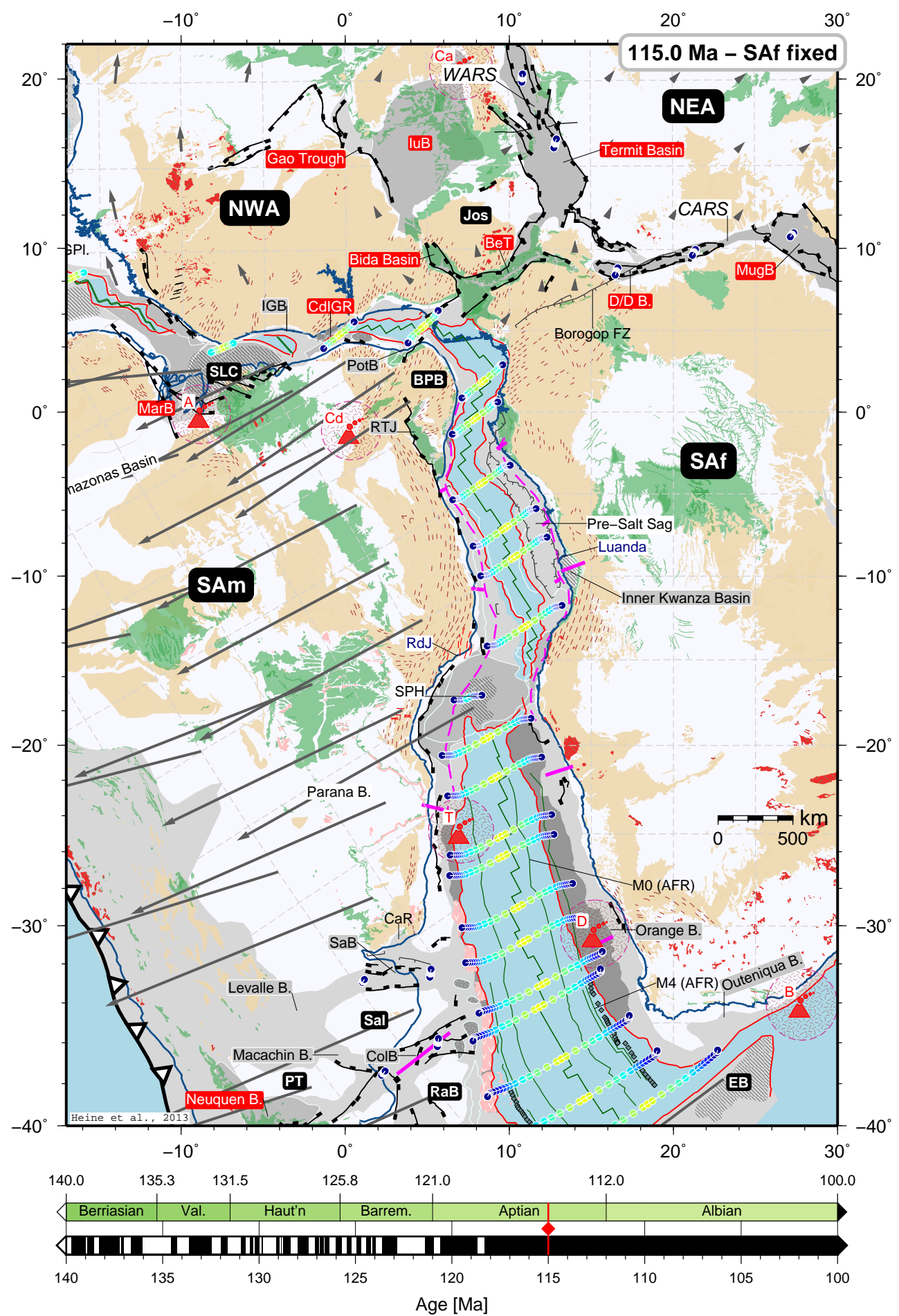

Fig. 19. Plate tectonic reconstruction at $115 \mathrm{Ma}$, with Africa fixed in present-day coordinates. For map legend see Fig. 22, abbreviations as in Fig. 13. Continental break-up has occurred along most parts of the conjugate South American/southern African and NW African margins apart from the "Amazon" and Côte d'Ivoire/Ghana transform segment of the equatorial Atlantic. Oceanic accretion has already commenced in the Deep Ghanaian Basin. In the SARS, only the Benguela-Walvis/Santos segment have not yet broken up. In this segment, extension is focussed asymmetrically close to the African margin, east of the São Paulo High. Basins in southern South America have entered the post-rift phase, and no significant relative motions between the rigid lithospheric blocks occur in post-Barremian times. Post-rift thermal subsidence and possible gravitationally induced flow of evaporite deposits towards the basin axis occurs in conjugate margin segments of the central SARS. 


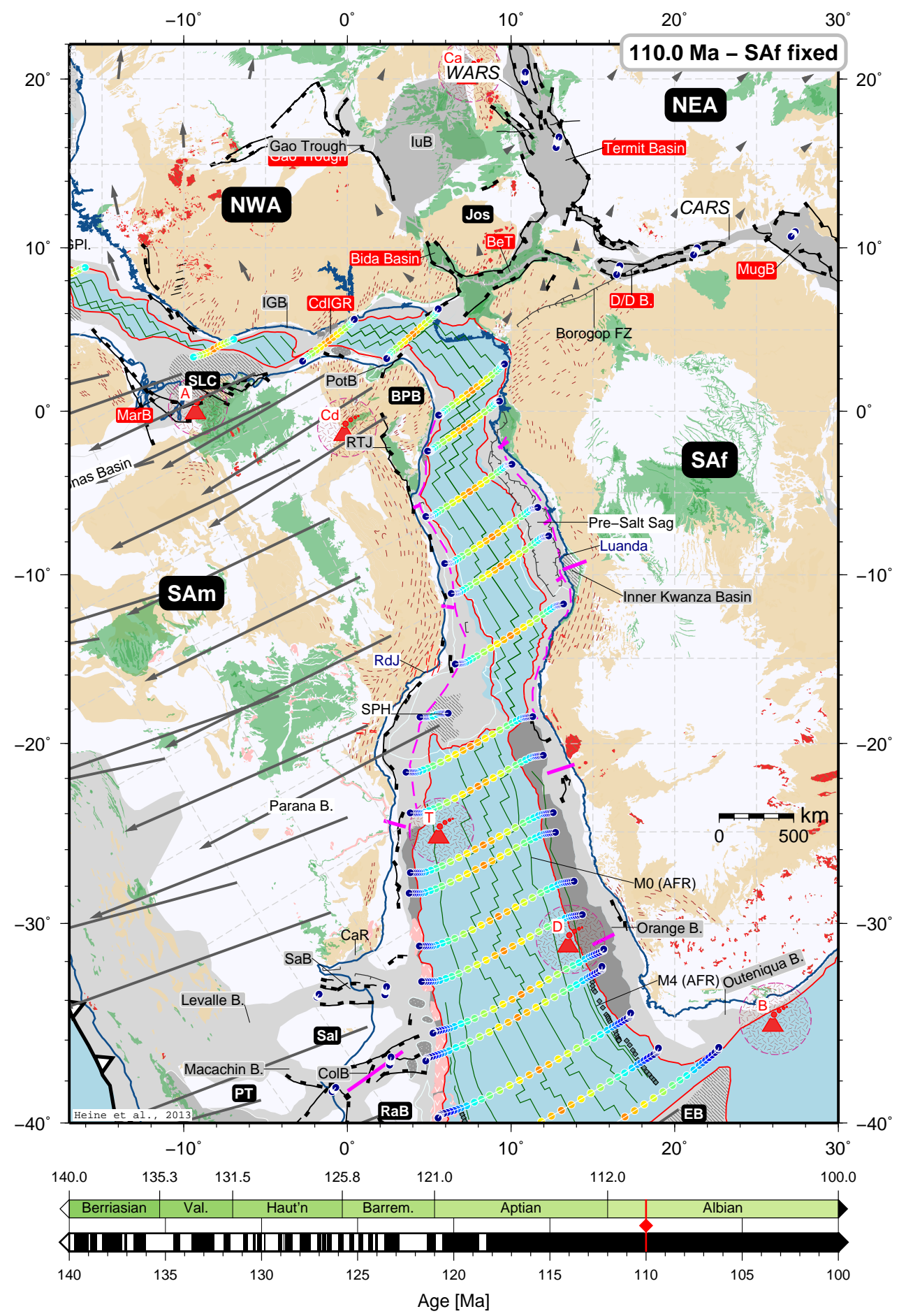

Fig. 20. Plate tectonic reconstruction at $110 \mathrm{Ma}$, with Africa fixed in present-day coordinates. For map legend see Fig. 22, abbreviations as in Fig. 13. Full continental separation is achieved at this time, with narrow oceanic gateways now opening between the Côte d'Ivoire/Ghana Ridge and the Piaui-Céara margin in the proto-equatorial Atlantic and between the Ewing Bank and Aghulas Arch in the southernmost South Atlantic. Deformation related to the break-up between Africa and South America in the African intracontinental rifts ceases in post-Aptian times. Towards the top Aptian, break-up between South America and Africa has largely been finalised. The only remaining connections are between major offset transfer faults in the equatorial Atlantic rift and between the outermost Santos Basin and the Benguela margin where a successively deepening oceanic gateway between the northern and southern proto-South Atlantic is proposed. Seafloor spreading is predicted for the conjugate passive-margin segments such as the Deep Ghanaian Basin (DGB). The stage pole rotation between SAm and NWA predicts compression along the CdIGR in accordance with observed uplift during this time (e.g. Pletsch et al., 2001; Clift et al., 1997). Abbreviations: CdIGR - Côte d'Ivoire/Ghana Ridge; EB - Maurice Ewing Bank. 


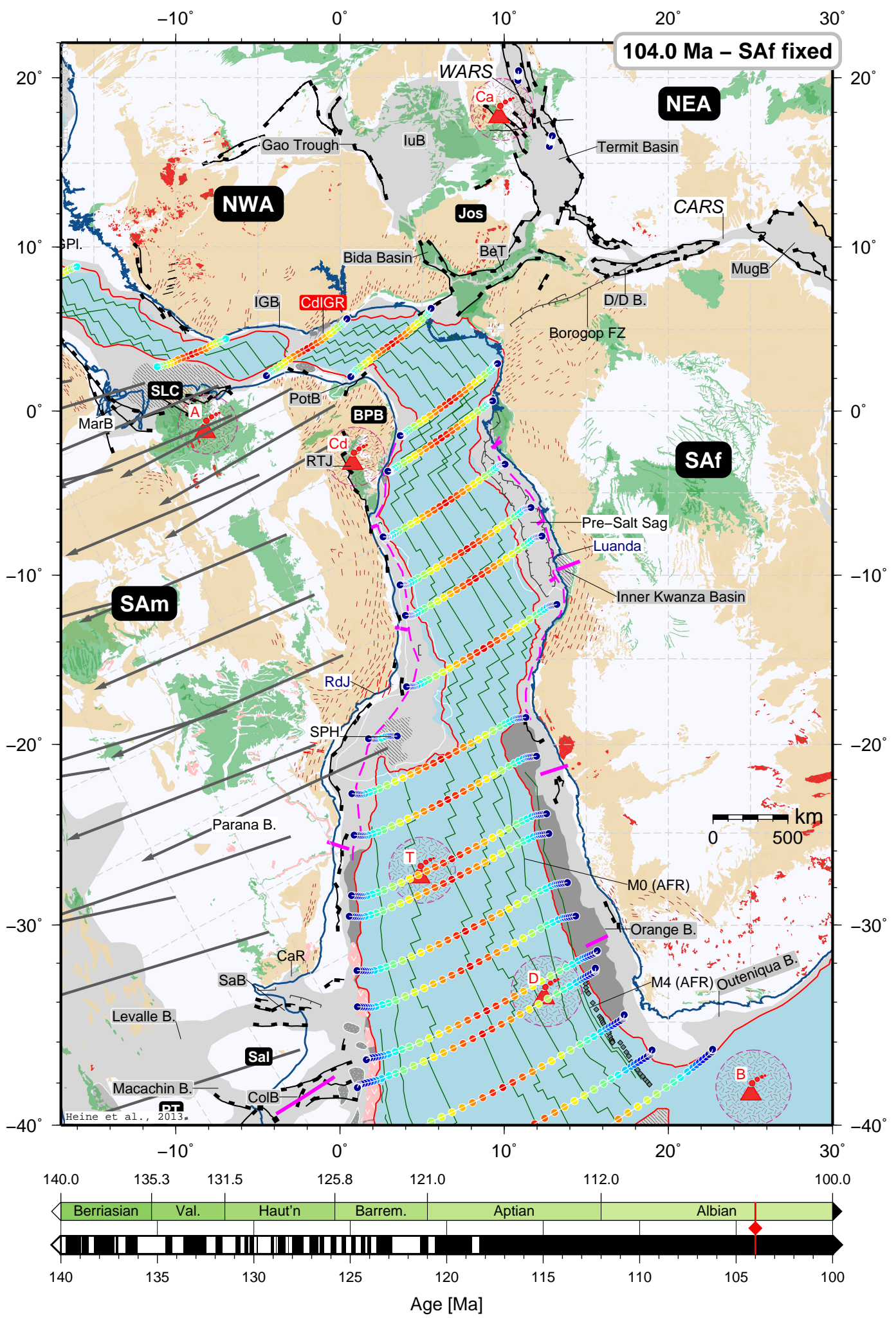

Fig. 21. Plate tectonic reconstruction at $104 \mathrm{Ma}$, with Africa fixed in present-day coordinates. For map legend see Fig. 22, abbreviations as in Fig. 13. Full continental separation is achieved at this time, with narrow oceanic gateways now opening between the Côte d'Ivoire/Ghana Ridge and the Piaui-Céara margin in the proto-equatorial Atlantic and between the Ewing Bank and Aghulas Arch in the southernmost South Atlantic. Deformation related to the break-up between Africa and South America in the African intracontinental rifts ceases in post-Aptian times. 


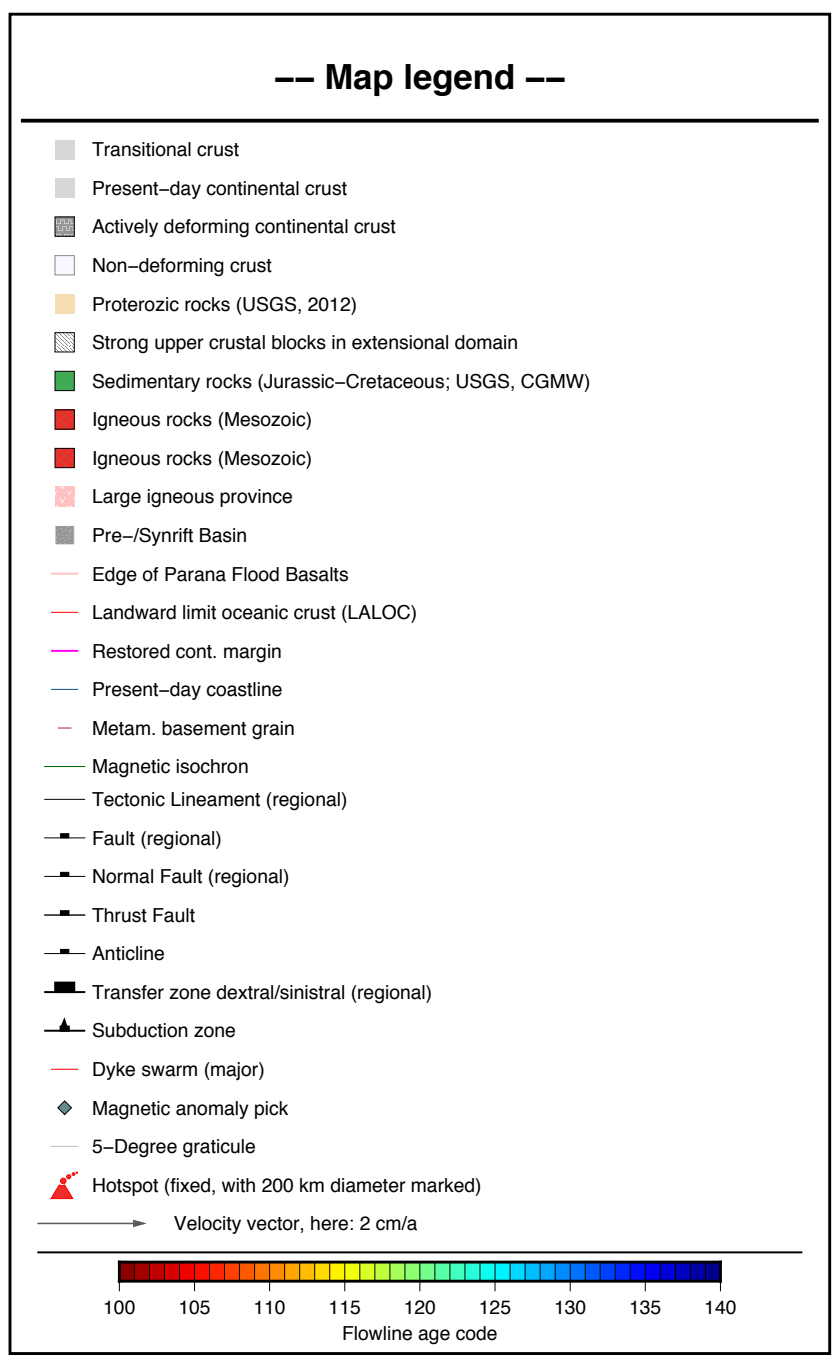

Fig. 22. Map legend for Figs. 13-21.

We conclude that our multi-direction, multi-velocity extension history can consistently explain the key events related to continental break-up in the South Atlantic rift realm, including the formation of the enigmatic pre-salt sag basin.

The plate kinematic framework presented in this paper is robust and comprehensive, shedding new light on the spatiotemporal evolution of the evolving South Atlantic rift system. However, problems remain with regard to the absolute timing of events in the evolution of the South Atlantic rift due to a lacking coherent stratigraphy for both conjugate margin systems, and limited access to crustal-scale seismic data. Relatively old and limited data for the African intraplate rifts result in large uncertainties in both absolute timing as well as structural constraints on the kinematics of rifting, which we have attempted to minimise in this comprehensive approach.

Strengthening the kinematic framework for the South Atlantic rift also offers an ideal laboratory to investigate the interaction between large-scale plate tectonics and lithosphere dynamics during rifting, and the relationship between plume activity, rift kinematics and the formation of volcanic/nonvolcanic margins.

Data and high-resolution images related to the publication are provided with the manuscript and can be freely accessed under a Creative Commons license at the Datahub under the following URL: http://datahub.io/en/ dataset/southatlanticrift.

\section{Supplementary material related to this article is available online at: http://www.solid-earth.net/4/215/ 2013/se-4-215-2013-supplement.zip.}

Acknowledgements. We would like to thank Statoil for permission to publish this work. C. Heine and J. Zoethout are indebted to many colleagues in Statoil's South Atlantic new venture teams, specialist groups, and R\&D who have contributed in various aspects to an inital version of the model. In particular we would like to thank Hans Christian Briseid, Leo Duerto, Rob Hunsdale, Rosie Fletcher, Eric Blanc, Tommy Mogensen Egebjerg, Erling Vågnes, Jakob Skogseid, and Ana Serrano-Oñate for discussions and valuable feedback. Feedback from Patrick Unternehr, Ritske Huismans, Julia Autin and Hannes Koopmann on various aspects of our work are kindly acknowledged. C. Heine thanks John Cannon and Paul Wessel for numerous fast software bug fixes. Editor Douwe J. J. v. Hinsbergen, an anonymous reviewer and Dieter Franke are thanked for constructive reviews and comments which improved the discussion version of the paper. Dieter Franke also kindly supplied digitised SDR outlines and structural data for the Argentine margin.

Plate reconstructions were made using the open-source software GPlates (http://www.gplates.org); all figures were generated using GMT (http://gmt.soest.hawaii.edu; Wessel and Smith, 1998). Structural restorations were partly done using Midland Valley's Move software with an academic software license to The University of Sydney.

C. Heine is funded by ARC Linkage Project L1759 supported by Shell International E\&P and TOTAL. J. Zoethout publishes with permission from Statoil ASA. R. D. Müller is supported by ARC Laureate Fellowship FL0992245.

Edited by: D. J. J. van Hinsbergen

\section{References}

Adeniyi, J.: Geophysical investigations of the central part of Niger State, Nigeria, Ph.D. thesis, University of WisconsinMadison, http://madcat.library.wisc.edu/cgi-bin/Pwebrecon.cgi? BBID=909335, 1984.

Almeida, F. F. M. d., Brito Neves, B. B. d., and Dal Ré Carneiro, C.: The origin and evolution of the South American Platform, EarthSci. Rev., 50, 77-111, doi:10.1016/S0012-8252(99)00072-0, 2000 . 
Amante, C. and Eakins, B. W.: ETOPO1 1 Arc-Minute Global Relief Model: Procedures, Data Sources and Analysis, Noaa technical memorandum, NESDIS NGDC-24, 2009.

Andersen, O. B., Knudsen, P., and Berry, P.: The DNSC08GRA global marine gravity field from double retracked satellite altimetry, J. Geodesy, 84, doi:10.1007/s00190-009-0355-9, 2010.

Antobreh, A. A., Faleide, J. I., Tsikalas, F., and Planke, S.: Rift-shear architecture and tectonic development of the Ghana margin deduced from multichannel seismic reflection and potential field data, Mar. Petrol. Geol., 26, 345-368, doi:10.1016/j.marpetgeo.2008.04.005, 2009.

Aslanian, D. and Moulin, M.: Comment on "A new scheme for the opening of the South Atlantic Ocean and the dissection of an Aptian salt basin" by Trond H. Torsvik, Sonia Rousse, Cinthia Labails and Mark A. Smethurst, Geophys. J. Int., doi:10.1111/j.1365-246X.2010.04727.x, 2010.

Azevedo, R. P. D.: Tectonic Evolution Of Brazilian Equatorial Continental Margin Basins, Ph.D. thesis, Department of Geology, Royal School of Mines, Imperial College, Prince Consort Road, London SW7 2BP, 1991.

Barr, D.: 3-D palinspastic restoration of normal faults in the Inner Moray Firth: implications for extensional basin development, Earth Planet. Sci. Lett., 75, 191-203, doi:10.1016/0012821X(85)90101-3, 1985.

Basile, C., Mascle, J., and Guiraud, R.: Phanerozoic geological evolution of the Equatorial Atlantic domain, J. African Earth Sci., 43, 275-282, doi:10.1016/j.jafrearsci.2005.07.011, 2005.

Basile, C., Maillard, A., Patriat, M., Gaullier, V., Loncke, L., Roest, W., Mercier de Lépinay, M., and Pattier, F.: Structure and evolution of the Demerara Plateau, offshore French Guiana: Rifting, tectonic inversion and post-rift tilting at transform-divergent margins intersection, Tectonophysics, doi:10.1016/j.tecto.2012.01.010, 2013.

Bassi, G.: Relative importance of strain rate and rheology for the mode of continental extension, 122, 195-210, doi:10.1111/j.1365-246X.1995.tb03547.x, 1995.

Bate, R. H.: Non-marine ostracod assemblages of the Pre-Salt rift basins of West Africa and their role in sequence stratigraphy, in: The Oil and Gas Habitats of the South Atlantic, edited by Cameron, N. R., Bate, R. H., and Clure, V. S., Vol. 153 of Special Publications, 283-292, Geol. Soc. Lond., doi:10.1144/GSL.SP.1999.153.01.17, 1999.

Bauer, K., Neben, S., Schreckenberger, B., Emmermann, R., Hinz, K., Fechner, N., Gohl, K., Schulze, A., Trumbull, R. B., and Weber, K.: Deep structure of the Namibia continental margin as derived from integrated geophysical studies, J. Geophys. Res., 105, 25829-25853, doi:10.1029/2000JB900227, 2000.

Benkhelil, J.: Benue Trough and Benue Chain, Geological Magazine, 119, 155-168, 1982.

Benkhelil, J.: The origin and evolution of the Cretaceous Benue Trough (Nigeria), Journal of African Earth Sciences (and the Middle East), 8, 251-282, doi:10.1016/S0899-5362(89)80028-4, 1989.

Benkhelil, J., Mascle, J., and Tricart, P.: The Guinea continental margin: an example of a structurally complex transform margin, Tectonophysics, 248, 117-137, doi:10.1016/00401951(94)00246-6, 1995.

Berggren, W. A., Kent, D. V., Swisher III, C. C., and Aubry, M. P.: A revised Cenozoic geochronology and chronostratigraphy, in:
Geochronology, Time Scales, and Global Stratigraphic Correlation, edited by: Berggren, W. A., Kent, D., Aubry, M.-P., and Hardenbol, J., Vol. 54 of Special Publication, 129-212, SEPM Soc. Sediment. Geol., 1995.

Binks, R. M. and Fairhead, J. D.: A plate tectonic setting for Mesozoic rifts of West and Central Africa, Tectonophysics, 213, 141151, doi:10.1016/0040-1951(92)90255-5, 1992.

Bird, P.: An updated digital model of plate boundaries, Geochem. Geophys. Geosyst., 4, 1027, doi:10.1029/2001GC000252, 2003.

Blaich, O. A., Faleide, J. I., Tsikalas, F., Franke, D., and León, E.: Crustal-scale architecture and segmentation of the Argentine margin and its conjugate off South Africa, Geophys. J. Int., 178, 85-105, doi:10.1111/j.1365-246X.2009.04171.x, 2009.

Blaich, O. A., Faleide, J. I., and Tsikalas, F.: Crustal breakup and continent-ocean transition at South Atlantic conjugate margins, J. Geophys. Res., 116, B01402, doi:10.1029/2010JB007686, 2011.

Bosworth, W.: Mesozoic and early Tertiary rift tectonics in East Africa, Tectonophysics, 209, 115-137, doi:10.1016/00401951(92)90014-W, 1992.

Bransden, P. J. E., Burges, P., Durham, M. J., and Hall, J. G.: Evidence for multi-phase rifting in the North Falklands Basin, in: Cameron et al. (1999), 425-443, doi:10.1144/GSL.SP.1999.153.01.26, 1999.

Browne, S. and Fairhead, J.: Gravity study of the Central African Rift system: A model of continental disruption 1. The Ngaoundere and Abu Gabra Rifts, Tectonophysics, 94, 187-203, doi:10.1016/0040-1951(83)90016-1, 1983.

Browne, S., Fairhead, J., and Mohamed, I.: Gravity study of the White Nile Rift, Sudan, and its regional tectonic setting, Tectonophysics, 113, 123-137, doi:10.1016/0040-1951(85)90113-1, 1985.

Brownfield, M. E. and Charpentier, R. R.: Geology and Total Petroleum Systems of the West-Central Coastal Province (7203), West Africa, Bulletin 2207-B, 52 p., U.S. Geological Survey, http://www.usgs.gov/bul/2207/B/, 2006.

Buck, W. R., Lavier, L. L., and Poliakov, A. N. B.: How to make a rift wide, Phil. Trans. R. Soc. Lond. A., 357, 671-693, 1999.

Bumby, A. J. and Guiraud, R.: The geodynamic setting of the Phanerozoic basins of Africa, J. African Earth Sci., 43, 1-12, doi:10.1016/j.jafrearsci.2005.07.016, 2005.

Burke, K.: The Chad basin: An active intra-continental basin, Tectonophysics, 36, 197-206, doi:10.1016/00401951(76)90016-0, 1976.

Burke, K. and Dewey, J. F.: Two plates in Africa during the Cretaceous?, Nature, 249, 313-316, doi:10.1038/249313a0, 1974.

Burke, K., MacGregor, D. S., and Cameron, N. R.: Africa's petroleum systems: four tectonic "aces" in the past 600 million years, in: Petroleum geology of Africa: New themes and developing techniques, edited by: Arthur, T., MacGregor, D. S., and Cameron, N. R., Vol. 207 of Special Publications, 21-60, Geol. Soc. Lond., doi:10.1144/GSL.SP.2003.207.01.03, 2003.

Cainelli, C. and Mohriak, W. U.: Some remarks on the evolution of sedimentary basins along the eastern Brazilian continental margin, Episodes, 22, 206-216, 1999.

Cameron, N. R., Bate, R. H., and Clure, V. S., eds.: The Oil and Gas Habitats of the South Atlantic, Vol. 153 of Special Publication, Geol. Soc. Lond., doi:10.1144/GSL.SP.1999.153.01.28, 1999.

Castro, A. C. M., J.: The northeastern Brazil and Gabon Basins: A double rifting system associated with multi- 
ple crustal detachment surfaces, Tectonics, 6, 727-738, doi:10.1029/TC006i006p00727, 1987.

Catuneanu, O., Wopfner, H., Eriksson, P. G., Cairncross, B., Rubidge, B. S., Smith, R. M. H., and Hancox, P. J.: The Karoo basins of south-central Africa, J. African Earth Sci., 43, 211253, doi:10.1016/j.jafrearsci.2005.07.007, 2005.

Chaboureau, A.-C., Guillocheau, F., Robin, C., Rohais, S., Moulin, M., and Aslanian, D.: Palaeogeographic evolution of the central segment of the South Atlantic during Early Cretaceous times: Palaeotopographic and geodynamic implications, Tectonophysics, doi:10.1016/j.tecto.2012.08.025, in press.

Chang, H. K.: Mapeamento e Interpretação dos Sistemas Petrolíferos da Sistemas Petrolíferos da Bacia de Santos, http://www.anp.gov.br/brnd/round5/round5/Apres_SemTec/ R5_Santos.pdf, 2004.

Chang, H. K., Kowsmann, R. O., Ferreira Figueiredo, A. M., and Bender, A. A.: Tectonics and stratigraphy of the East Brazil Rift system: an overview, Tectonophysics, 213, 97-138, doi:10.1016/0040-1951(92)90253-3, 1992.

Channell, J., Erba, E., Muttoni, G., and Tremolada, F.: Early Cretaceous magnetic stratigraphy in the APTICORE drill core and adjacent outcrop at Cismon (Southern Alps, Italy), and correlation to the proposed Barremian-Aptian boundary stratotype, Geol. Soc. Am. Bull., 112, 1430-1443, doi:10.1130/00167606(2000)112<1430:ECMSIT>2.0.CO;2, 2000.

Clemson, J., Cartwright, J., and Swart, R.: The Namib Rift: a rift system of possible Karoo age, offshore Namibia, in: Cameron et al. (1999), pp. 381-402, doi:10.1144/GSL.SP.1999.153.01.23, 1999.

Clift, P. D., Lorenzo, J. M., Carter, A., Hurford, A. J., and ODP Leg 159 Scientific Party: Transform tectonics and thermal rejuvenation on the Cote d'Ivoire-Ghana margin, west Africa, J. Geol. Soc. Lond., 154, 483-489, doi:10.1144/gsjgs.154.3.0483, 1997.

Cogné, J.-P. and Humler, E.: Trends and rhythms in global seafloor generation rate, Geochem. Geophys. Geosyst., 7, doi:10.1029/2005GC001148, 2006.

Contrucci, I., Matias, L., Moulin, M., Géli, L., Klingelhoefer, F., Nouzé, H., Aslanian, D., Olivet, J.-L., Réhault, J.-P., and Sibuet, J.-C.: Deep structure of the West African continental margin (Congo, Zaire, Angola), between $5^{\circ} \mathrm{S}$ and $8^{\circ} \mathrm{S}$, from reflection/refraction seismics and gravity data, Geophys. J. Int., 158, 529-553, doi:10.1111/j.1365-246X.2004.02303.x, 2004.

Costa, J. B. S., Léa Bemerguy, R., Hasui, Y., and da Silva Borges, M.: Tectonics and paleogeography along the Amazon river, J. South Am. Earth Sci., 14, 335-347, doi:10.1016/S08959811(01)00025-6, 2001

Costa, J. B. S., Hasui, Y., Bemerguy, R. L., Soares-Júnior, A. V., and Villegas, J. M. C.: Tectonics and paleogeography of the Marajó Basin, northern Brazil, Anais da Academia Brasileira de Ciências, 74, 519-531, doi:10.1590/S000137652002000300013, 2002.

Coward, M. P., Purdy, E. G., Ries, A. C., and Smith, D. G.: The distribution of petroleum reserves in basins of the South Atlantic margins, in: Cameron et al. (1999), 101-131, doi:10.1144/GSL.SP.1999.153.01.08, 1999.

Cratchley, C. R., Louis, P., and Ajakaiye, D. E.: Geophysical and geological evidence for the Benue-Chad Basin Cretaceous rift valley system and its tectonic implications, J. African Earth Sci., 2, 141-150, 1984.
Crosby, A., White, N., Edwards, G., and Shillington, D. J.: Evolution of the Newfoundland-Iberia Conjugate Rifted Margins, Earth Planet. Sci. Lett., 273, 214-226, doi:10.1016/j.eps1.2008.06.039, 2008.

Croveto, C. B., Novara, I. L., and Introcaso, A.: A stretching model to explain the Salado Basin (Argentina), Boletín del Instituto de Fisiografía y Geología, 77, 1-10, 2007.

da Cruz Cunha, P. R., Gonçalves de Melo, J. H., and da Silva, O. B.: Bacia do Amazonas, Boletim de Geociências da Petrobras, 15, 227-251, 2007.

Daly, M. C., Chorowicz, J., and Fairhead, J. D.: Rift basin evolution in Africa: the influence of reactivated steep basement shear zones, in: Inversion Tectonics, edited by: Cooper, M. A. and Williams, G. D., Vol. 44 of Special Publications, 309-334, Geol. Soc. Lond., doi:10.1144/GSL.SP.1989.044.01.17, 1989.

Davison, I.: Geology and tectonics of the South Atlantic Brazilian salt basins, in: Deformation of the Continental Crust: The Legacy of Mike Coward, edited by: Ries, A. C., Butler, R. W. H., and Graham, R. H., No. 272 in Special Publications,345-359, Geol. Soc. Lond., 2007.

de Oliveira, D. C. and Mohriak, W. U.: Jaibaras trough: an important element in the early tectonic evolution of the Parnaiba interior sag basin, Northern Brazil, Mar. Petrol. Geol., 20, 351-383, doi:10.1016/S0264-8172(03)00044-8, 2003.

Dunbar, J. A. and Sawyer, D. S.: Implications of continental crust extension for plate reconstruction: An example for the Gulf of Mexico, Tectonics, 6, 739-755, 1987.

Dupré, S., Bertotti, G., and Cloetingh, S. A. P. L.: Tectonic history along the South Gabon Basin: Anomalous early post-rift subsidence, Mar. Petrol. Geol., 24, 151-172, 2007.

Eagles, G.: New angles on South Atlantic opening, Geophys. J. Int., 168, 353-361, doi:10.1111/j.1365-246X.2006.03206.x, 2007.

Exxon Production Research Company: Tectonic Map of the World, American Association of Petroleum Geologists Foundation, Tulsa, OK, USA, 1985.

Eyles, N. and Eyles, C. H.: Glacial geologic confirmation of an intraplate boundary, in the Paraná basin of Brazil, Geology, 21, 459-462, doi:10.1130/00917613(1993)021<0459:GGCOAI > 2.3.CO;2, 1993.

Fairhead, J. D.: Mesozoic plate tectonic reconstructions of the central South Atlantic Ocean: The role of the West and Central African rift system, Tectonophysics, 155, 181-191, 1988.

Fairhead, J. D. and Binks, R. M.: Differential opening of the Central and South Atlantic Oceans and the opening of the West African rift system, Tectonophysics, 187, 191-203, doi:10.1016/00401951(91)90419-S, 1991.

Fairhead, J. D. and Okereke, C. S.: Crustal thinning and extension beneath the Benue Trough based on gravity studies, J. Afr. Earth Sci., 11, 329-335, doi:10.1016/0899-5362(90)90011-3, 1990.

Fairhead, J. D., Okereke, C. S., and Nnange, J. M.: Crustal structure of the Mamfe basin, West Africa, based on gravity data, Tectonophysics, 186, 351-358, doi:10.1016/00401951(91)90368-3, 1991.

Fairhead, J. D., Bournas, N., and Raddadi, M. C.: The Role of Gravity and Aeromagnetic Data in Mapping Mega Gondwana Crustal Lineaments: the Argentina - Brazil - Algeria (ABA) Lineament, in: International Exposition and 77th Annual Meeting, Society of Exploration Geophysicists, San Antonio TX, USA, 2007. 
Feng, M., van der Lee, S., and Assumpção, M.: Upper mantle structure of South America from joint inversion of waveforms and fundamental mode group velocities of Rayleigh waves, J. Geophys. Res., 112, doi:10.1029/2006JB004449, 2007.

Fetter, M.: The role of basement tectonic reactivation on the structural evolution of Campos Basin, offshore Brazil: Evidence from 3D seismic analysis and section restoration, Mar. Petrol. Geol., 26, 873-886, doi:10.1016/j.marpetgeo.2008.06.005, 2009.

Forsythe, R.: The late Palaeozoic to early Mesozoic evolution of southern South America: a plate tectonic interpretation, J. Geol. Soc., 139, 671-682, doi:10.1144/gsjgs.139.6.0671, 1982.

Fort, X., Brun, J.-P., and Chauvel, F.: Salt tectonics on the Angolan margin, synsedimentary deformation processes, AAPG Bulletin, 88, 1523-1544, doi:10.1306/06010403012, 2004.

Franke, D., Neben, S., Schreckenberger, B., Schulze, A., Stiller, M., and Krawczyk, C. M.: Crustal structure across the Colorado Basin, offshore Argentina, Geophys. J. Int., 165, 850-864, doi:10.1111/j.1365-246X.2006.02907.x, 2006.

Franke, D., Neben, S., Ladage, S., Schreckenberger, B., and Hinz, K.: Margin segmentation and volcano-tectonic architecture along the volcanic margin off Argentina/Uruguay, South Atlantic, Mar. Geol., 244, 46-67, doi:10.1016/j.margeo.2007.06.009, 2007.

Gee, J. S. and Kent, D. V.: Source of Oceanic Magnetic Anomalies and the Geomagnetic Polarity Timescale, in: Treatise on Geophysics, edited by: Kono, M., Vol. 5, Chap. 12, 455-507, Elsevier, Amsterdam, doi:10.1016/B978-044452748-6.00097-3, 2007.

Genik, G. J.: Regional framework, structural and petroleum aspects of rift basins in Niger, Chad and the Central African Republic (C.A.R.), Tectonophysics, 213, 169-185, doi:10.1016/00401951(92)90257-7, 1992.

Genik, G. J.: Petroleum Geology of Cretaceous-Tertiary Rift Basins in Niger, Chad, and Central African Republic, AAPG Bulletin, 77, 1405-1434, 1993.

Gibbs, A. D.: Structural evolution of extensional basin margins, J. Geol. Soc. Lond., 141, 609-620, 1984.

Gladczenko, T. P., Hinz, K., Eldholm, O., Meyer, H., Neben, S., and Skogseid, J.: South Atlantic volcanic margins, J. Geol. Soc., Lond., 154, 465-470, 1997.

Gomes, P. O., Kilsdonk, B., Minken, J., Grow, T., and Barragan, R.: The Outer High of the Santos Basin, Southern São Paulo Plateau, Brazil: Pre-Salt Exploration Outbreak, Paleogeographic Setting, and Evolution of the Syn-Rift Structures, in: AAPG International Conference and Exhibition, Search and Discovery Article \#10193, Cape Town, South Africa, October 26-29, 2008, 2009.

Gonzaga, F. G., Gonçalves, F. T. T., and Coutinho, L. F. C.: Petroleum geology of the Amazonas Basin, Brazil: modeling of hydrocarbon generation and migration, in: Petroleum systems of South Atlantic margins, edited by: Mello, M. R. and Katz, B. J., No. 73 in Memoir, Chap. 13, AAPG, 2000.

Gradstein, F., Ogg, J., Smith, A., Agterberg, F., Bleeker, W., Cooper, R., Davydov, V., Gibbard, P., Hinnov, L., House, M., Lourens, L., Luterbacher, H., McArthur, J., Melchin, M., Robb, L., Shergold, J., Villeneuve, M., Wardlaw, B., Ali, J., Brinkhuis, H., Hilgen, F., Hooker, J., Howarth, R., Knoll, A., Laskar, J., Monechi, S., Plumb, K., Powell, J., Raffi, I., Röhl, U., Sadler, P., Sanfilippo, A., Schmitz, B., Shackleton, N., Shields, G., Strauss, H., Van Dam, J., van Kolfschoten, T., Veizer, J., and Wilson, D.: A
Geologic Time Scale, Cambridge University Press, 2004.

Gradstein, F. M., Agterberg, F. P., Ogg, J. G., Hardenbol, J., van Veen, P., Thierry, J., and Huang, Z.: A Mesozoic time scale, J. Geophys. Res., 99, 24051-24074, doi:10.1029/94JB01889, 1994.

Greenroyd, C. J., Peirce, C., Rodger, M., Watts, A. B., and Hobbs, R. W.: Crustal structure of the French Guiana margin, West Equatorial Atlantic, Geophys. J. Int., 169, 964-987, 2007.

Greenroyd, C. J., Peirce, C., Rodger, M., Watts, A. B., and Hobbs, R. W.: Demerara Plateau the structure and evolution of a transform passive margin, Geophys. J. Int., 172, 549-564, doi:10.1111/j.1365-246X.2007.03662.x, 2008.

Guiraud, R. and Maurin, J.-C.: Early Cretaceous rifts of Western and Central Africa: an overview, Tectonophysics, 213, 153-168, doi:10.1016/0040-1951(92)90256-6, 1992.

Guiraud, R., Binks, R. M., Fairhead, J. D., and Wilson, M.: Chronology and geodynamic setting of Cretaceous-Cenozoic rifting in West and Central Africa, Tectonophysics, 213, 227234, doi:10.1016/0040-1951(92)90260-D, 1992.

Guiraud, R., Bosworth, W., Thierry, J., and Delplanque, A.: Phanerozoic geological evolution of Northern and Central Africa: An overview, J. African Earth Sci., 43, 83-143, doi:10.1016/j.jafrearsci.2005.07.017, 2005.

Haq, B. U., Hardenbol, J., and Vail, P. R.: Chronology of fluctuating sea levels since the Triassic, Science, 235, 1156-1167, 1987.

He, H., Pan, Y., Tauxe, L., Qin, H., and Zhu, R.: Toward age determination of the MOr (Barremian-Aptian boundary) of the Early Cretaceous, Phys. Earth Planet. Int., 169, 41-48, doi:10.1016/j.pepi.2008.07.014, 2008.

Heine, C. and Brune, S.: Breaking the Cratonic Equatoiral Atlantic Bridge: Why there is no Saharan Ocean, in: DGG/GV/GSA Conference "Fragile Earth", Munich, Germany, http://gsa.confex. com/gsa/2011FE/finalprogram/abstract_189822.htm, 2011.

Heine, C., Müller, R. D., Steinberger, B., and Torsvik, T. H.: Subsidence in intracontinental basins due to dynamic topography, Phys. Earth Planet. Int., 171, 252-264, doi:10.1016/j.pepi.2008.05.008, 2008.

Homovc, J. F. and Constantini, L.: Hydrocarbon Exploration Potential within Intraplate Shear-Related Depocenters: Deseado and San Julian Basins, Southern Argentina, AAPG Bulletin, 85, 1795-1816, doi:10.1306/8626D077-173B-11D78645000102C1865D, 2001.

Huismans, R. and Beaumont, C.: Depth-dependent extension, twostage breakup and cratonic underplating at rifted margins, Nature, 473, 74-78, doi:10.1038/nature09988, 2011.

Jacques, J. M.: A tectonostratigraphic synthesis of the Sub-Andean basins: inferences on the position of South American intraplate accommodation zones and their control on South Atlantic opening, J. Geol. Soc. Lond., 160, 703-717, 2003.

Janssen, M. E., Stephenson, R. A., and Cloetingh, S.: Temporal and spatial correlations between changes in plate motions and the evolution of rifted basins in Africa, Geol. Soc. Am. Bull., 107, 1317-1332, 1995.

Jones, E. J. W.: Fracture zones in the equatorial Atlantic and the breakup of western Pangea, Geology, 15, 533536, doi:10.1130/0091-7613(1987)15<533:FZITEA > 2.0.CO;2, 1987.

Jones, S. M., White, N. J., Faulkner, P., and Bellingham, P.: Animated models of extensional basins and pas- 
sive margins, Geochem. Geophys. Geosyst., 5, Q08009, doi:10.1029/2003GC000658, 2004.

Karner, G. D. and Gambôa, L. A. P.: Timing and origin of the South Atlantic pre-salt sag basins and their capping evaporites, in: Evaporites Through Space and Time, edited by: Schreiber, B., Lugli, S., and Babel, M., No. 285 in Special Publications, Geol. Soc. Lond., 2007.

Karner, G. D., Driscoll, N. W., McGinnis, J. P., Brumbaugh, W. D., and Cameron, N. R.: Tectonic significance of syn-rift sediment packages across the Gabon-Cabinda continental margin, Mar. Petrol. Geol., 14, 973-1000, 1997.

Karner, G. D., Manatschal, G., and Pinheiro, L.-M., eds.: Imaging, Mapping and Modelling Continental Lithosphere Extension and Breakup, No. 282 in Special Publication, Geol. Soc., 2007.

Kirstein, L. A., Peate, D. W., Hawkesworth, C. J., Turner, S. P., Harris, C., and Mantovani, M. S. M.: Early Cretaceous Basaltic and Rhyolitic Magmatism in Southern Uruguay Associated with the Opening of the South Atlantic, J. Petrol., 41, 1413-1438, doi:10.1093/petrology/41.9.1413, 2000.

König, M. and Jokat, W.: The Mesozoic breakup of the Weddell Sea, J. Geophys. Res., 111, B12102, doi:10.1029/2005JB004035, 2006.

Laske, G.: A New Global Crustal Model at $2 \times 2$ Degrees, http:// igppweb.ucsd.edu/ $\sim$ gabi/crust2.html, 2004.

Lavier, L. L. and Manatschal, G.: A mechanism to thin the continental lithosphere at magma-poor margins, Nature, 440, doi:10.1038/nature04608, 2006.

Lawrence, S. R., Munday, S., and Bray, R.: Regional geology and geophysics of the eastern Gulf of Guinea (Niger Delta to Rio Muni), The Leading Edge, 21, 1112-1117, 2002.

Le Pichon, X. and Sibuet, J. C.: Passive margins: A model of formation, J. Geophys. Res., 86, 3708-3720, 1981.

Li, Z. X., Bogdanova, S. V., Collins, A. S., Davidson, A., De Waele, B., Ernst, R. E., Fitzsimons, I. C. W., Fuck, R. A., Gladkochub, D. P., Jacobs, J., Karlstrom, K. E., Lu, S., Natapov, L. M., Pease, V., Pisarevsky, S. A., Thrane, K., and Vernikovsky, V.: Assembly, configuration, and break-up history of Rodinia: A synthesis, Precambrian Research, 160, 179-210, doi:10.1016/j.precamres.2007.04.021, 2008.

Macdonald, D., Gomez-Pereza, I., Franzese, J., Spalletti, L., Lawver, L., Gahagan, L., Dalziel, I., Thomas, C., Trewind, N., Holed, M., and Patona, D.: Mesozoic break-up of SW Gondwana: implications for regional hydrocarbon potential of the southern South Atlantic, Mar. Petrol. Geol., 20, 287-308, doi:10.1016/S0264-8172(03)00045-X, 2003.

Magnavita, L. P., Davison, I., and Kusznir, N. J.: Rifting, erosion, and uplift history of the Recòncavo-Tucano-Jatobà Rift, northeast Brazil, Tectonics, 13, 367-388, doi:10.1029/93TC02941, 1994.

Mann, P.: Global catalogue, classification and tectonic origins of restraining- and releasing bends on active and ancient strike-slip fault systems, 290, 13-142, doi:10.1144/SP290.2, 2007.

Maslanyj, M. P., Light, M. P. R., Greenwood, R. J., and Banks, N. L.: Extension tectonics offshore Namibia and evidence for passive rifting in the South Atlantic, Mar. Petrol. Geol., 9, 590601, doi:10.1016/0264-8172(92)90032-A, 1992.

Matos, R. M. D. d.: The Northeast Brazilian Rift System, Tectonics, 11, 766-791, doi:10.1029/91TC03092, 1992.
Matos, R. M. D. d.: History of the northeast Brazilian rift system: kinematic implications for the break-up between Brazil and West Africa, in: The Oil and Gas Habitats of the South Atlantic, edited by: Cameron, N. R., Bate, R. H., and Clure, V. S., Vol. 153 of Special Publications, 55-73, Geol. Soc. Lond., doi:10.1144/GSL.SP.1999.153.01.04, 1999.

Matos, R. M. D. d.: Tectonic evolution of the equatorial South Atlantic, in: Atlantic Rifts and Continental Margins, edited by: Mohriak, W. U. and Talwani, M., Vol. 115 of Geophys. Monogr. Ser., 331-354, American Geophysical Union, doi:10.1029/GM115p0331, 2000.

Matos, R. M. D. d. and Brown, L. D.: Deep seismic profile of the Amazonian Craton (northern Brazil), Tectonics, 11, 621-633, doi:10.1029/91TC03091, 1992.

Maurin, J.-C. and Guiraud, R.: Basement control in the development of the early cretaceous West and Central African rift system, Tectonophysics, 228, 81-95, doi:10.1016/0040-1951(93)902156, 1993.

Maus, S., Sazonova, T., Hemant, K., Fairhead, J. D., and Ravat, D.: National Geophysical Data Center candidate for the World Digital Magnetic Anomaly Map, Geochem. Geophys. Geosyst. Technical Brief, 8, Q06017, doi:10.1029/2007GC001643, 2007.

Max, M. D., Ghidella, M., Kovacs, L., Paterlini, M., and Valladares, J. A.: Geology of the Argentine continental shelf and margin from aeromagnetic survey, Mar. Petrol. Geol., 16, 41-64, doi:10.1016/S0264-8172(98)00063-4, http: //www.sciencedirect.com/science/article/B6V9Y-3VKSDC6-3/ 2/1e22d18befbb4a3bc9ca7939ea1fe5dd, 1999.

McHargue, T. R., Heidrick, T. L., and Livingston, J. E.: Tectonostratigraphic development of the Interior Sudan rifts, Central Africa, Tectonophysics, 213, 187-202, doi:10.1016/00401951(92)90258-8, 1992.

Meisling, K. E., Cobbold, P. R., and Mount, V. S.: Segmentation of an obliquely rifted margin, Campos and Santos basins, southeastern Brazil, AAPG Bull., 85, 1903-1924, 2001.

Milani, E. J. and Davison, I.: Basement control and transfer tectonics in the Recòncavo-Tucano-Jatobà rift, Northeast Brazil, Tectonophysics, 154, 41-50, 53-70, doi:10.1016/00401951(88)90227-2, 1988.

Mitchell, C., Taylor, G. K., Cox, K. G., and Shaw, J.: Are the Falkland Islands a rotated microplate?, Nature, 319, 131-134, doi:10.1038/319131a0, 1986.

Mittelstaedt, E., Ito, G., and Behn, M. D.: Mid-ocean ridge jumps associated with hotspot magmatism, Earth Planet. Sci. Lett., 266, 256-270, doi:10.1016/j.epsl.2007.10.055, 2008.

Modica, C. J. and Brush, E. R.: Postrift sequence stratigraphy, paleogeography, and fill history of the deep-water Santos Basin, offshore southeast Brazil, AAPG Bulletin, 88, 923-945, doi:10.1306/01220403043, 2004.

Mohamed, A. Y., Ashcroft, W. A., and Whiteman, A. J.: Structural development and crustal stretching in the Muglad Basin, southern Sudan, J. African Earth Sci., 32, 179-191, doi:10.1016/S0899-5362(01)90003-X, 2001.

Mohriak, W. U. and Rosendahl, B. R.: Transform zones in the South Atlantic rifted continental margins, in: Intraplate Strike-Slip Deformation Belts, edited by: Storti, F., Holdsworth, R. E., and Salvini, F., Vol. 210 of Special Publications, 211-228, Geol. Soc. Lond., 2003. 
Mohriak, W. U., Bassetto, M., and Vieira, I. S.: Tectonic Evolution of the Rift Basins in the Northeastern Brazilian Region, in: Atlantic Rifts and Continental Margins, edited by: Mohriak, W. U. and Talwani, M., Vol. 115 of Geophys. Monogr. Ser., 293-315, AGU, Washington, DC, doi:10.1029/GM115p0293, 2000.

Mohriak, W. U., Nobrega, M., Odegard, M. E., Gomes, B. S., and Dickson, W. G.: Geological and geophysical interpretation of the Rio Grande Rise, south-eastern Brazilian margin: extensional tectonics and rifting of continental and oceanic crusts, Petrol. Geosci., 16, 231-245, doi:10.1144/1354-079309-910, 2010.

Morley, C. K., Bosworth, W., Day, R., Lauck, R., Bosher, R., Stone, D., Wigger, S., Wescott, W., Haun, D., and Bassett, N.: Geology and Geophysics of the Anza Graben, in: Geoscience of Rift Systems-Evolution of East Africa, edited by Morley, C. K., No. 44 in AAPG Studies in Geology, Chap. 4, 67-90, Amer. Assoc. Petr. Geol., Tulsa, OK, United States, http://archives. datapages.com/data/specpubs/study44/st44ch04/ch4.htm, 1999.

Moulin, M., Aslanian, D., and Unternehr, P.: A new starting point for the South and Equatorial Atlantic Ocean, Earth-Science Rev., 97, 59-95, doi:10.1016/j.earscirev.2009.08.001, 2009.

Moulin, M., Aslanian, D., Rabineau, M., Patriat, M., and Matias, L.: Kinematic keys of the Santos-Namibe basins, in: Conjugate Divergent Margins, edited by: Mohriak, W. U., Danforth, A., Post, P. J., Brown, D. E. abd Tari, G. C., Nemčok, M., and Sinha, S. T., Vol. 369 of Special Publications, Geol. Soc. Lond., doi:10.1144/SP369.3, 2012.

Müller, R. D., Sdrolias, M., Gaina, C., and Roest, W. R.: Age, spreading rates, and spreading asymmetry of the world's ocean crust, Geochem. Geophys. Geosyst., 9, Q04006, doi:10.1029/2007GC001743, 2008.

Norton, I. O. and Sclater, J. G.: A model for the evolution of the Indian Ocean and the breakup of Gondwanaland, J. Geophys. Res., 84, 6803-6830, doi:10.1029/JB084iB12p06803, 1979.

Nunn, J. A. and Aires, J. R.: Gravity Anomalies and Flexure of the Lithosphere at the Middle Amazon Basin, Brazil, J. Geophys. Res., 93, 415-428, doi:10.1029/JB093iB01p00415, 1988.

Nürnberg, D. and Müller, R. D.: The tectonic evolution of the South Atlantic from Late Jurassic to present, Tectonophysics, 191, 2753, doi:10.1016/0040-1951(91)90231-G, 1991.

Obaje, N. G., Wehner, H., Scheeder, G., Abubakar, M. B., and Jauro, A.: Hydrocarbon prospectivity of Nigeria's inland basins: From the viewpoint of organic geochemistry and organic petrology, AAPG Bulletin, 88, 325-353, doi:10.1306/10210303022, 2004.

Ogg, J. G.: Geomagnetic Polarity Time Scale, in: The Geologic Time Scale 2012, edited by: Gradstein, F. M., Ogg, J. G., Schmitz, M., and Ogg, G., Chap. 5, Elsevier, doi:10.1016/B9780-444-59425-9.00005-6, 2012.

Ogg, J. G. and Hinnov, L.: Cretaceous, in: The Geologic Time Scale 2012, edited by: Gradstein, F. M., Ogg, J. G., Schmitz, M., and Ogg, G., Chap. 27, 793-853, Elsevier, doi:10.1016/B978-0-44459425-9.00027-5, 2012.

Oliveira, L. O. A.: Aspectos da evolucao termomecanica da Bacia do Parana no Brasil, Revista Brasileira de Geociências, 19, 330 $-342,1989$.

O'Neill, C., Müller, D., and Steinberger, B.: On the uncertainties in hot spot reconstructions and the significance of moving hot spot reference frames, Geochem. Geophys. Geosyst., 6, Q04003, doi:10.1029/2004GC000784, 2005.
Pángaro, F. and Ramos, V. A.: Paleozoic crustal blocks of onshore and offshore central Argentina: New pieces of the southwestern Gondwana collage and their role in the accretion of Patagonia and the evolution of Mesozoic south Atlantic sedimentary basins, Mar. Petrol. Geol., 37, 162-183, doi:10.1016/j.marpetgeo.2012.05.010, 2012.

Paton, D. A. and Underhill, J. R.: Role of crustal anisotropy in modifying the structural and sedimentological evolution of extensional basins: the Gamtoos Basin, South Africa, Basin Res., 16, 339-359, doi:10.1111/j.1365-2117.2004.00237.x, 2004.

Peate, D. W.: The Paraná-Etendeka Province, in: Large Igneous Provinces: Continental, Oceanic, and Planetary Flood Volcanism, edited by: Mahoney, J. J. and Coffin, M. F., Vol. 100 of Geophysical Monograph, 217-245, American Geophysical Union, doi:10.1029/GM100p0217, 1997.

Pérez-Gussinyé, M., Lowry, A. R., and Watts, A. B.: Effective elastic thickness of South America and its implications for intracontinental deformation, Geochem. Geophys. Geosyst., 8, Q05009, doi:10.1029/2006GC001511, 2007.

Péron-Pinvidic, G. and Manatschal, G.: The final rifting evolution at deep magma-poor passive margins from Iberia-Newfoundland: a new point of view, Int. J. Earth Sci. (Geol. Rundschau), 98, 15811597, doi:10.1007/s00531-008-0337-9, 2009.

Petters, S. W.: Stratigraphy of Chad and Iullemmeden basins (West Africa), Eclogae Geologicae Helvetiae, 74, 139-159, doi:10.5169/seals-165095, 1981.

Pletsch, T., Erbacher, J., Holbourn, A., Kuhnt, W., Moullade, M., Oboh-Ikuenobede, F., Söding, E., and Wagner, T.: Cretaceous separation of Africa and South America: the view from the West African margin (ODP Leg 159), J. South Am. Earth Sci., 14, 147-174, doi:10.1016/S0895-9811(01)00020-7, 2001.

Plomerová, J., Babuška, V., Dorbath, C., Dorbath, L., and Lillie, R. J.: Deep lithospheric structure across the Central African Shear Zone in Cameroon, Geophys. J. Int., 115, 381-390, 1993.

Popoff, M.: Du Gondwana à l'atlantique sud: les connexions du fossé de la Bénoué avec les bassins du Nord-Est brésilien jusqu'à l'ouverture du golfe de Guinée au crétacé inférieur, Journal of African Earth Sciences (and the Middle East), 7, 409-431, doi:10.1016/0899-5362(88)90086-3, 1988.

Poropat, S. F. and Colin, J.-P.: Early Cretaceous ostracod biostratigraphy of eastern Brazil and western Africa: An overview, Gondwana Research, 22, 772-798, doi:10.1016/j.gr.2012.06.002, 2012.

Rabinowitz, P. D. and LaBrecque, J.: The Mesozoic south Atlantic Ocean and evolution of its continental margins, J. Geophys. Res., 84, 5973-6002, 1979.

Ramos, V. A.: Late Proterozoic-early Paleozoic of South America; a Collisional History, Episodes, 11, 168-174, 1988.

Ramos, V. A.: Patagonia: A paleozoic continent adrift?, J. South Am. Earth Sci., 26, 235-251, 2008.

Reeves, C. V., Karanja, F. M., and MacLeod, I. N.: Geophysical evidence for a failed Jurassic rift and triple junction in Kenya, Earth Planet. Sci. Lett., 81, 299-311, doi:10.1016/0012821X(87)90166-X, 1987.

Reston, T. J.: The opening of the central segment of the South Atlantic: symmetry and the extension discrepancy, Petrol. Geosci., 16, 199-206, doi:10.1144/1354-079309-907, 2010.

Rosendahl, B. R. and Groschel-Becker, H.: Deep seismic structure of the continental margin in the Gulf of Guinea: 
a summary report, in: Cameron et al. (1999), 75-83, doi:10.1144/GSL.SP.1999.153.01.05, 1999.

Ross, M. I. and Scotese, C. R.: A hierarchical tectonic model of the Gulf of Mexico and Caribbean region, Tectonophysics, 155, 139-168, doi:10.1016/0040-1951(88)90263-6, 1988.

Rudge, J. F., Shaw Champion, M. E., White, N., McKenzie, D., and Lovell, B.: A plume model of transient diachronous uplift at the Earth's surface, Earth Planet. Sci. Lett., 267, 146-160, doi:10.1016/j.epsl.2007.11.040, 2008.

Rüpke, L. H., Schmalholz, S. M., Schmid, D., and Podladchikov, Y. Y.: Automated thermotectonostratigraphic basin reconstruction: Viking Graben case study, AAPG Bulletin, 92, 1-18, doi:10.1306/11140707009, 2008.

Sandwell, D. T. and Smith, W. H. F.: Global marine gravity from retracked Geosat and ERS-1 altimetry: Ridge segmentation versus spreading rate, J. Geophys. Res., 114, B01411, doi:10.1029/2008JB006008, 2009.

Sawyer, D. S.: Total Tectonic Subsidence: A Parameter for Distinguishing Crust Type at the U.S. Atlantic Continental Margin, J. Geophys. Res., 90, 7751-7769, doi:10.1029/JB090iB09p07751, 1985.

Schull, T. J.: Rift Basins of Interior Sudan: Petroleum Exploration and Discovery, AAPG Bulletin, 72, 1128-1142, doi:10.1306/703C9965-1707-11D7-8645000102C1865D, 1988.

Scotchman, I. C., Gilchrist, G., Kusznir, N. J., Roberts, A. M., and Fletcher, R.: The breakup of the South Atlantic Ocean: formation of failed spreading axes and blocks of thinned continental crust in the Santos Basin, Brazil and its consequences for petroleum system development, in: Petroleum Geology: From Mature Basins to New Frontiers-Proceedings of the 7th Petroleum Geology Conference, edited by: Vining, B. A. and Pickering, S. C., Vol. 7 of Petroleum Geology Conference series, 855-866, Geol. Soc. Lond., doi:10.1144/0070855, 2010.

Séranne, M. and Anka, Z.: South Atlantic continental margins of Africa: A comparison of the tectonic vs climate interplay on the evolution of equatorial west Africa and SW Africa margins, J. Afr. Earth Sci., 43, 283-300, doi:10.1016/j.jafrearsci.2005.07.010, 2005.

Seton, M., Müller, R. D., Gaina, C., and Heine, C.: Mid-Cretaceous seafloor spreading pulse: Fact or fiction?, Geology, 37, 687-690, doi:10.1130/G25624A.1, 2009.

Seton, M., Müller, R. D., Zahirovic, S., Gaina, C., Torsvik, T. H., Shephard, G. E., Talsma, A., Gurnis, M., Turner, M., Maus, S., and Chandler, M.: Global continental and ocean basin reconstructions since 200 Ma, Earth-Sci. Rev., 113, 212-270, doi:10.1016/j.earscirev.2012.03.002, 2012.

Sibuet, J.-C., Hay, W. W., Prunier, A., Montadert, L., Hinz, K., and Fritsch, J.: Early Evolution of the South Atlantic Ocean: Role of the Rifting Episode, in: Initial reports of the Deep Sea Drilling Project covering Leg 75 of the cruises of the drilling vessel Glomar Challenger, Walvis Bay, South Africa to Recife, Brazil, JulySeptember, 1980, edited by: Hay, W. W., Sibuet, J.-C., , Barron, E. J., Brassell, S. C., Dean, W. E., Huc, A. Y., Keating, B. H., McNulty, C. L., Meyers, P. A., Nohara, M., Schallreuter, R. E. L., Steinmetz, J. C., Stow, D. A. V., Stradner, H., Boyce, R. E., and Amidei, R., Vol. 75, 469-481, Texas A \& M University, Ocean Drilling Program, College Station, TX, United States, doi:10.2973/dsdp.proc.75.107.1984, 1984.
Soares Júnior, A. V., Hasui, Y., Costa, J. B. S., and Machado, F. B.: Evolução do rifteamento e Paleogeografia da Margem Atlântica Equatorial do Brasil: Triássico ao Holoceno, Revista Geociências, 30, 669-692, http://geociencias.no-ip.org/30 4/Art_13_Soares_Jr_et_al.pdf, 2011.

Somoza, R. and Zaffarana, C. B.: Mid-Cretaceous polar standstill of South America, motion of the Atlantic hotspots and the birth of the Andean cordillera, Earth Planet. Sci. Lett., 271, 267-277, doi:10.1016/j.eps1.2008.04.004, 2008.

Soto, M., Morales, E., Veroslavsky, G., de Santa Ana, H., Ucha, N., and Rodríguez, P.: The continental margin of Uruguay: Crustal architecture and segmentation, Mar. Petrol. Geol., 28, 16761689, doi:10.1016/j.marpetgeo.2011.07.001, 2011.

Stanton, N., Schmitt, R., Galdeano, A., Maia, M., and Mane, M.: Crustal structure of the southeastern Brazilian margin, Campos Basin, from aeromagnetic data: New kinematic constraints, Tectonophysics, 490, 15-27, doi:10.1016/j.tecto.2010.04.008, 2010.

Steinberger, B. and Torsvik, T. H.: Absolute plate motions and true polar wander in the absence of hotspot tracks, Nature, 452, 620623, doi:10.1038/nature06824, 2008.

Stewart, K., Turner, S., Kelley, S., Hawkesworth, C., Kirstein, L., and Mantovani, M.: 3-D, 40Ar/39Ar geochronology in the Paraná continental flood basalt province, Earth Planet. Sci. Lett., 143, 95-109, doi:10.1016/0012-821X(96)00132-X, 1996.

Stoakes, F. A., Campbell, C. V., Cass, R., and Ucha, N.: Seismic Stratigraphic Analysis of the Punta Del Este Basin, Offshore Uruguay, South America, AAPG Bulletin, 75, 219-240, 1991.

Stone, P., Richards, P., Kimbell, G., Esser, R., and Reeves, D.: Cretaceous dykes discovered in the Falkland Islands: implications for regional tectonics in the South Atlantic, J. Geol. Soc., 165, 1-4, doi:10.1144/0016-76492007-072, 2008.

Stuart, G. W., Fairhead, J. D., Dorbath, L., and Dorbath, C.: A seismic refraction study of the crustal structure associated with the Adamawa Plateau and Garoua Rift, Cameroon, West Africa, Geophys. J. Roy. Astro. Soc., 81, 1-12, doi:10.1111/j.1365246X.1985.tb01346.x, 1985.

Sykes, T. J. S.: A correction for sediment load upon the ocean floor: Uniform versus varying sediment density estimationsimplications isostatic correction, Mar. Geol., 133, 35-49, 1996.

Szatmari, P. and Milani, E. J.: Microplate rotation in northeast Brazil during South Atlantic rifting: Analogies with the Sinai microplate, Geology, 27, 1115-1118, doi:10.1130/00917613(1999)027<1115:MRINBD>2.3.CO;2, 1999.

Torsvik, T. H., Müller, R. D., Van der Voo, R., Steinberger, B., and Gaina, C.: Global Plate Motions Frames: Toward a unified model, Rev. Geophys., 46, RG3004, doi:10.1029/2007RG000227, 2008.

Torsvik, T. H., Rousse, S., Labails, C., and Smethurst, M. A.: A new scheme for the opening of the South Atlantic Ocean and the dissection of an Aptian salt basin, Geophys. J. Int., 177, 13151333, doi:10.1111/j.1365-246X.2009.04137.x, 2009.

Turner, J. P., Rosendahl, B. R., and Wilson, P. G.: Structure and evolution of an obliquely sheared continental margin: Rio Muni, West Africa, Tectonophysics, 374, 41-55, doi:10.1016/S00401951(03)00325-1, 2003.

Turner, S., Regelous, M., Kelley, S., Hawkesworth, C., and Mantovani, M.: Magmatism and continental break-up in the South Atlantic: high precision 40Ar-39Ar geochronology, Earth Planet. 
Sci. Lett., 121, 333-348, doi:10.1016/0012-821X(94)90076-0, 1994.

United States Geological Survey: Energy Resources Program: World Geologic Maps, http://energy.usgs.gov/ OilGas/AssessmentsData/WorldPetroleumAssessment/ WorldGeologicMaps.aspx, 2012.

Unternehr, P., Curie, D., Olivet, J. L., Goslin, J., and Beuzart, P.: South Atlantic fits and intraplate boundaries in Africa and South America, Tectonophysics, 155, 169-179, doi:10.1016/00401951(88)90264-8, 1988.

Unternehr, P., Peron-Pinvidic, G., Manatschal, G., and Sutra, E.: Hyper-extended crust in the South Atlantic: in search of a model, Petrol. Geosci., 16, 207-215, doi:10.1144/1354-079309904, 2010.

Urien, C. M., Zambrano, J. J., and Yrigoyen, M. R.: Petroleum Basins of Southern South America: An Overview, Vol. 62 of AAPG Memoir, AAPG, 1995.

von Gosen, W. and Loske, W.: Tectonic history of the Calcatapul Formation, Chubut province, Argentina, and the "Gastre fault system", J. South Am. Earth Sci., 18, 73-88, doi:10.1016/j.jsames.2004.08.007, 2004.

Webster, R. E., Chebli, G. A., and Fischer, J. F.: General Levalle basin, Argentina: A frontier Lower Cretaceous rift basin, AAPG Bulletin, 88, 627-652, doi:10.1306/01070403014, 2004.
Wessel, P. and Smith, W. H. F.: New, improved version of Generic Mapping Tools released, EOS Trans. Am. Geophys. Union, 79, 579, 1998.

White, N.: Nature of lithospheric extension in the North Sea, Geology, 17, 111-114, 1989.

White, R. S. and McKenzie, D.: Magmatism at rift zones: the generation of volcanic continental margins and flood basalts, J. Geophys. Res., 94, 7685-7729, doi:10.1029/JB094iB06p07685, 1989.

Wright, J. B.: South Atlantic continental drift and the Benue Trough, Tectonophysics, 6, 301-310, doi:10.1016/00401951(68)90046-2, 1968.

Zalán, P. V., do Carmo G. Severino, M., Rigoti, C. A., Magnavita, L. P., Bach de Oliveira, J. A., and Roessler Vianna, A.: An Entirely New 3D-View of the Crustal and Mantle Structure of a South Atlantic Passive Margin - Santos, Campos and Espírito Santo Basins, Brazil, in: AAPG Annual Convention and Exhibition, Search and Discovery Article \#30177, American Association of Petroleum Geologists, Houston, Texas, USA, http://www.searchanddiscovery. com/documents/2011/30177zalan/ndx_zalan.pdf, 2011.

Zambrano, J. J. and Urien, C. M.: Geological Outline of the Basins in Southern Argentina and Their Continuation off the Atlantic Shore, J. Geophys. Res., 75, 1363-1396, doi:10.1029/JB075i008p01363, 1970. 